\title{
THE ROLE OF ISLAND-ARC OCEANIC, COLLISIONAL AND INTRAPLATE MAGMATISM IN THE FORMATION OF CONTINENTAL CRUST IN THE MONGOLIA-TRASNBAIKALIA REGION: GEOSTRUCTURAL, GEOCHRONOLOGICAL AND Sm-Nd ISOTOPE DATA
}

\section{I.V. Gordienko ${ }^{凶}$}

Geological Institute, Siberian Branch of the Russian Academy of Science, 6 Sakhyanova St, Ulan-Ude 670047, Buryatian Republic, Russia

ABSTRACT. The formation of continental crust in the Mongolia-Transbaikalia region is researched to identify the mechanisms of interactions between the crust and the mantle in the development of the Neoarchean, Proterozoic and Paleozoic magmatic and sedimentary complexes in the study area. Using the results of his own studies conducted for many years and other published data on this vast region of Central Asia, the author have analysed compositions, ages and conditions for the formation of Karelian, Baikalian, Caledonian and Hercynian structure-formational complexes in a variety of geodynamic settings. Based on the geostructural, petrological, geochemical, geochronological and Sm-Nd isotope data, he determines the crustal and mantle sources of magmatism, conducts the identification and mapping of isotopic provinces, and reveals the role of island-arc oceanic, accretion-collision and intraplate magmatism in the formation of continental crust. Considering the formation of the bulk continental crust, three main stages are distinguished: (1) Neoarchean and Paleoproterozoic (Karelian) (almost 30\% of the crust volume), (2) Meso-Neoproterozoic (Baikalian) (50\%), and (3) Paleozoic (Caledonian and Hercynian) (over 20\%). This sequence of the evolution stages shows the predominance of the ancient crustal material in igneous rocks sources at the early stage. During the subsequent stages, tectonic structures created earlier were repeatedly reworked, and mixed crustal-mantle and juvenile sources were widely involved in the formation of the bulk continental crust in the study area.

KEYWORDS: Mongolia-Transbaikalia region; oceanic crust; island arc; accretion; collision; intraplate magmatism; Sm-Nd model age; source; isotope province; continental crust

FUNDING: The study was financially supported by the Earth Sciences Department of the Russian Academy of Sciences (Programme IX.124.1 - Deep Geodynamics and Evolution of the Lithosphere: Regularities in the Occurrence of Mantle Plumes and Plate Tectonic Processes, Dynamics of Sedimentary Basins (Coordinator: Academician of RAS N.L. Dobretsov), the Laboratory of Geodynamics, Geological Institute SB RAS (Budget Item IX.124.1.1; State No. AAAA-A17-11701160013-4), and the Russian Foundation for Basic Research (projects 15-05-01633a and 19-05-00312a) (Project Leader: Corresponding Member of RAS I.V. Gordienko).

\section{RESEARCH ARTICLE}

Correspondence: Ivan V. Gordienko, gord@pres.bscnet.ru
Received: September 2, 2020

Revised: October 14, 2020

Accepted: February 2, 2021

FOR CITATION: Gordienko I.V., 2021. The role of island-arc oceanic, collisional and intraplate magmatism in the formation of continental crust in the Mongolia-Trasnbaikalia region: geostructural, geochronological and Sm-Nd isotope data. Geodynamics \& Tectonophysics 12 (1), 1-47. doi:10.5800/GT-2021-12-1-0510 


\title{
РОЛЬ ОСТРОВОДУЖНО-ОКЕАНИЧЕСКОГО, КОЛЛИЗИОННОГО И ВНУТРИПЛИТНОГО МАГМАТИЗМА В ФОРМИРОВАНИИ КОНТИНЕНТАЛЬНОЙ КОРЫ МОНГОЛО-ЗАБАЙКАЛЬСКОГО РЕГИОНА: ПО СТРУКТУРНО-ГЕОЛОГИЧЕСКИМ, ГЕОХРОНОЛОГИЧЕСКИМ И Sm-Nd ИЗОТОПНЫМ ДАННЫМ
}

\author{
И.В. Гордиенко
}

Геологический институт СО РАН, 670047, Улан-Удэ, ул. Сахьяновой, 6, Республика Бурятия, Россия

\begin{abstract}
АННОТАЦИЯ. Целью данного фундаментального исследования являлось изучение процессов формирования континентальной коры Монголо-Забайкальского региона. Главной задачей было выявление механизмов коровомантийного взаимодействия в процессе массового образования неоархей-протерозой-палеозойских магматических и осадочных комплексов при становлении континентальной коры. В результате многолетних исследований автора в обширном регионе Центральной Азии был проанализирован вещественный состав, возраст и условия образования карельских, байкальских, каледонских и герцинских структурно-формационных комплексов различных геодинамических обстановок. На основе структурно-геологических, петролого-геохимических, геохронологических и $\mathrm{Sm}-\mathrm{Nd}$ изотопных данных определены коровые и мантийные источники магматизма, выделены изотопные провинции и показана роль островодужно-океанических, аккреционно-коллизионных и внутриплитных взаимосвязанных процессов в образовании континентальной коры региона. Выделено три главных этапа формирования основной массы коры: 1) неоархей-палеопротерозойский (карельский) - около 30 \%, 2) мезонеопротерозойский (байкальский) - 50 \% и 3) палеозойский (каледонский и герцинский), на который приходится более 20 \% объема созданной коры. Такой эволюционный ряд указывает на преобладание в источниках магматических пород раннего этапа формирования древнего корового материала. В последующие этапы в результате неоднократной переработки созданных ранее тектонических структур был сформирован основной объем континентальной коры региона с широким участием смешанных корово-мантийных и ювенильных источников.
\end{abstract}

КЛЮЧЕВЫЕ СЛОВА: Монголо-Забайкальский регион; океаническая кора; островная дуга; аккреция; коллизия; внутриплитный магматизм; Sm-Nd модельный возраст; источник; изотопная провинция; континентальная кора

ФИНАНСИРОВАНИЕ. Исследования выполнены при финансовой поддержке Отделения наук о Земле РАН по программе IX.124.1. «Глубинная геодинамика и эволюция литосферы: закономерности проявления мантийных плюмов и плитотектонических процессов, динамика осадочных бассейнов» (координатор акад. РАН Н.Л. Добрецов), бюджетной темы лаборатории геодинамики ГИН СО РАН IX.124.1.1. (гос. номер АAАA-A17-11701160013-4) и РФФИ (проекты № 15-05-01633а, 19-05-00312а) (рук. чл.-корр. РАН И.В. Гордиенко).

Посвящается памяти выдающегося ученого академика Н.Л. Добрещова, внесшего огромный вклад в изучение тектоники, магматизма, метаморфизма и геодинамической эволюции Земли

\section{1. ВВЕДЕНИЕ}

Формирование континентальной коры и в целом литосферы Земли относится к числу фундаментальных проблем геологии. Этой проблемой занимались многие исследователи из разных стран на протяжении всей длительной истории изучения геологического строения и эволюции Земли: от ранней геосинклинальной концепции до появления в 60-70-х годах прошлого века новой глобальной тектоники на основе мобилизма и глубинной геодинамики. Согласно современной геологической парадигме - тектонике литосферных плит и глубинной геодинамике - было установлено, что складчатые (орогенические) пояса возникли на месте океанов и их активных окраин. Они являются результатом взаимодействия и эволюции океанических и окраинно-континентальных структур с преобразованием океанической коры в континентальную [Dietz, 1961; Peive, 1969; Dewey, Bird, 1970; Zonenshayn, 1972; Le Pichon et al., 1973; Dobretsov, 1981, 2011a, 2011b; Zonenshayn, Kuz `min, 1983; Maruyama et al., 1994; Hofmann, 1997; Dobretsov et al., 2001; Zhao, 2007; Li, Zhong, 2009; Condie, 2011; Cawood et al., 2013; Kuzmin, Yarmolyuk, 2016].

Мобилистская концепция развития складчатых поясов впервые была применена при создании международной карты становления континентальной коры Северной Евразии, где по времени формирования гранитно-метаморфического слоя были выделены и показаны три главных стадии образования континентальной коры: океаническая, переходная и континентальная [Peive et al., 1976]. Последующее изучение складчатых поясов и платформ послужило основой для составления новой геодинамической карты территории СССР и в дальнейшем Атласа тектонических карт Северной, Центральной и Восточной Азии и сопредельных территорий [Zonenshayn et al., 1990; Petrov et al., 2014], выполненных на принципах историзма и мобилизма. В подготовке Атласа тектонических карт Азии для территории Монголо-Забайкальского региона принимали 
участие в составе авторского коллектива А.Н. Булгатов, И.В. Гордиенко [Bulgatov, Gordienko, 2014] и 0. Томуртогоо [Tomurtogoo, 2014]. В развитии складчатых поясов было выделено пять взаимосвязанных стадий: 1) начальная, или океаническая; 2) зрелая, или островодужная; 3 ) средняя, или коллизионная; 4) поздняя, или постколлизионная; 5) завершающая, или рифтогенно- континентальная [Khain, Lomize, 2005; Sklyarov et al., 2002; Gordienko, 1987, 2008; Gladkochub, 2004; Dobretsov, 2011b] (рис. 1).

В тектоническом строении рассматриваемого Монголо-Забайкальского региона, входящего в состав Центрально-Азиатского складчатого пояса (ЦАСП), отчетливо проявились все вышеназванные стадии развития

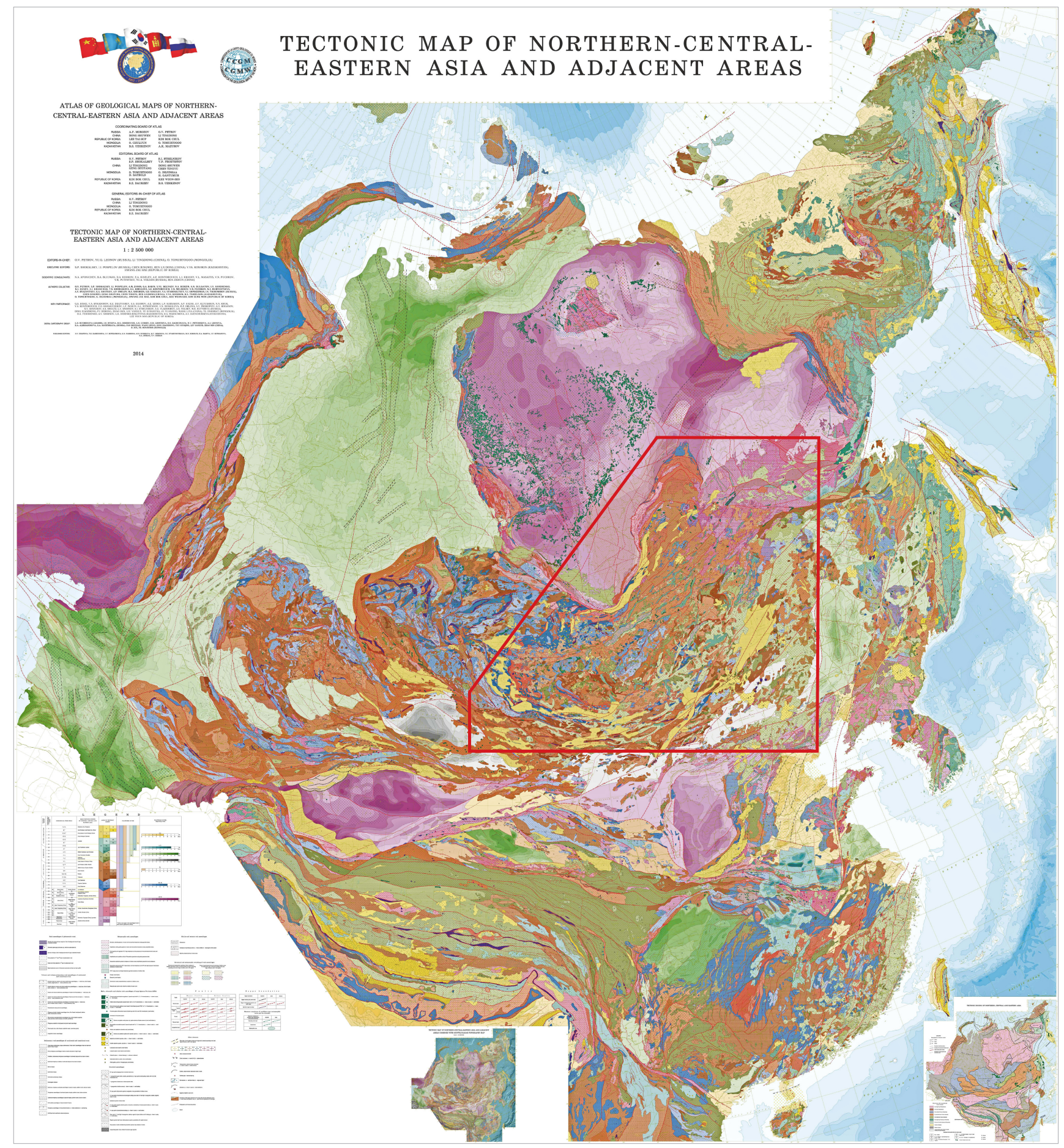

Рис. 1. Тектоническая карта Центральной, Северной и Восточной Азии и сопредельных территорий [Petrov et al., 2014]. Красной линией показан контур Монголо-Забайкальского региона.

Fig. 1. Tectonic map of the Central, Northern and Eastern Asia and adjacent areas [Petrov et al., 2014]. Red contour - MongoliaTransbaikalia region. 
складчатых поясов. В связи с этим при обобщении материалов и привязке изученных магматических комплексов к определенным тектоническим структурам мы придерживались традиционного расчленения территории на структурно-формационные зоны, в то время как последующая интерпретация материалов и определение геодинамических условий формирования магматизма произведены с использованием плитно-тектонических методов, в том числе террейнового анализа [Parfenov et al., 1995; Gordienko, 1987, 2001; Bulgatov, Gordienko, 1999, 2002, 2014]. Установлено, что в расшифровке происхождения образованных тектонических структур при формировании континентальной коры основную индикаторную роль, как независимые глубинные эндогенные факторы, играют проявления магматизма (магматические формации) различной тектонической природы [Kuznetsov, 1964,1973]. В этот период интенсивно развивался формационный анализ магматических комплексов с выделением формаций по их вещественному составу. Результатом этих работ явилось составление и издание карт магматических формаций СССР, Монгольской Народной Республики, Восточной Сибири и других регионов, проведение реконструкций по возрастным срезам с составлением Атласа палеовулканологических карт СССР и отдельных регионов с участием автора, которые сыграли огромную роль в интерпретации глубинных процессов в земной коре и мантии Земли при формировании континентальной коры исследованного Монголо-Забайкальского региона и были использованы нами в данной работе [Gordienko et al., 1978; Masaitis, 1979; Gordienko, 1981, 1986, 1987, 2003; Yanshin, 1989; Abramovich et al, 1990; Bulgatov et al., 1997; Luchitsky, 2001].

В конце 90-х и начале 2000-х годов, в связи с появлением более современных методов изотопно-геохронологических и геохимических исследований, проблема формирования континентальной коры Забайкалья и Монголии получила новый импульс и была рассмотрена в целом ряде опубликованных работ [Kovalenko et al., 1996, 1999, 2003; Yarmolyuk et al., 1999, 2002; Kovach et al., 2011; Kozakov et al., 2003, 2007]. В результате названных и других работ, с учетом имеющихся у авторов на то время Sm-Nd изотопных данных, была опубликована цветная схематическая карта изотопных провинций ЦАСП, на которой была показана превалирующая роль протолитов каледонской провинции в формировании континентальной коры Монголо-Забайкальского региона [Kovalenko et al., 2004, 2006; Bogatikov et al., 2010] (рис. 2).

В пределах северной части Байкальской складчатой области было установлено два этапа формирования континентальной коры: раннебайкальский и позднебайкальский. При этом указывалось, что на раннебайкальском этапе переработка древней континентальной

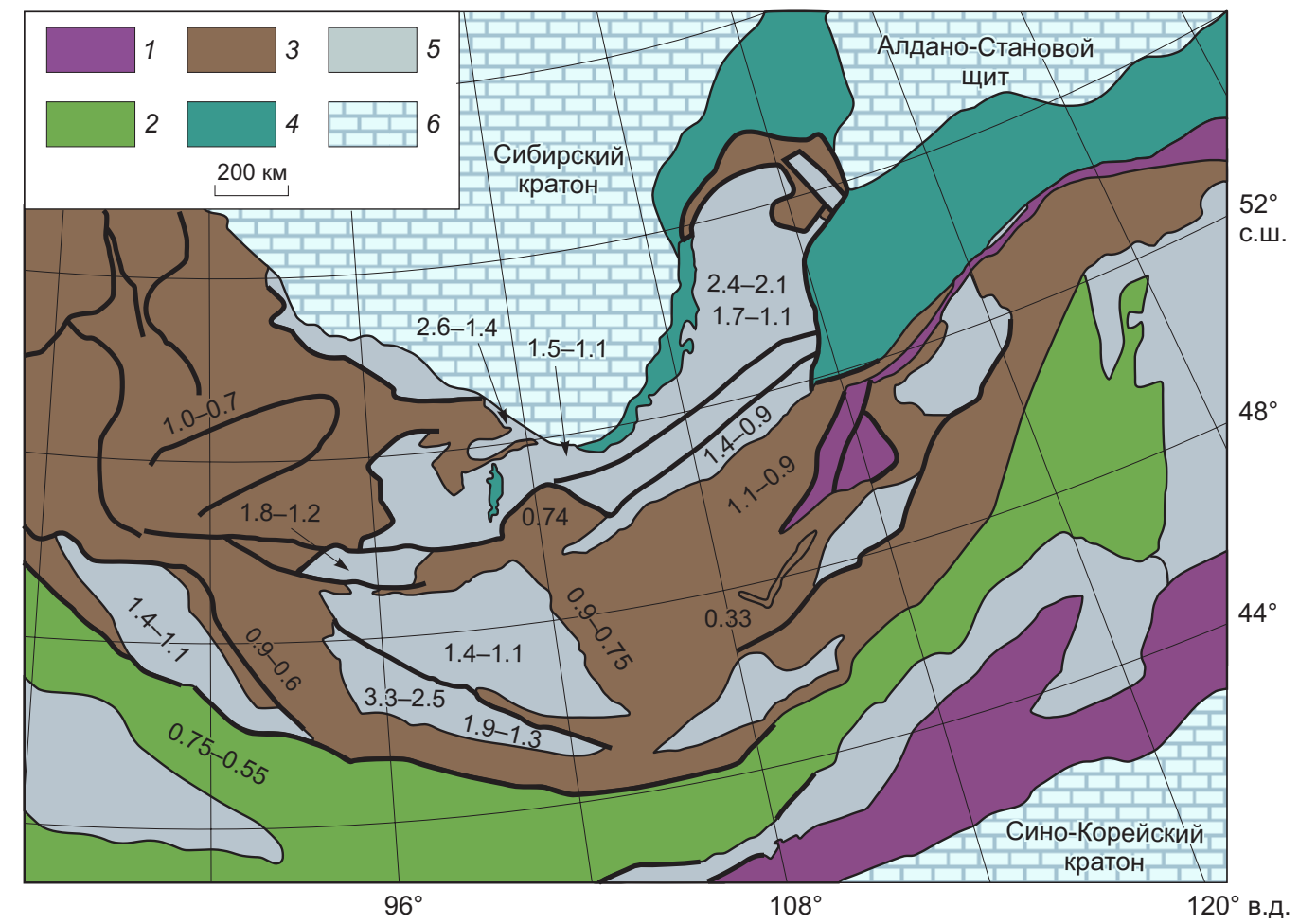

Рис. 2. Схематическая карта изотопных провинций Центрально-Азиатского складчатого пояса [Kovalenko et al., 2004, 2006]. Цифрами показаны вариации $\mathrm{Nd}$ модельных возрастов протолитов, млрд лет. Изотопные провинции: 1 - индосиниды, 2 герциниды, 3 - каледониды, 4 - дорифеиды, 5 - рифеиды, в том числе микроконтиненты, 6 - кратоны.

Fig. 2. Isotope provinces in the schematic map of the Central Asian fold belt [Kovalenko et al., 2004, 2006]. Numbers - variations of protolith $\mathrm{Nd}$ model ages, billion years. Isotope provinces: 1 - Indosinides, 2 - Hercinides, 3 - Caledonides, 4 Doripheids, 5 - Ripheids, including microcontinents, 6 - cratons. 
коры происходила в пределах узких троговых зон красноморского типа, где отмечались фрагменты океанической коры. На позднебайкальском этапе были установлены участки смешанных источников (коровых и ювенильных) с преобладанием древнекорового материала [Rytsk et al., 2007, 2011].

В этот же период активно проводилось изучение $\mathrm{Nd}$ изотопных систем более древних (архей-палеопротерозойских) этапов развития континентальной коры южной части Сибирского кратона в пределах Присаянского и Прибайкальского выступов, а также Акитканского вулканического пояса и Чуйского краевого поднятия. В результате этих работ было установлено, что южная часть кратона состоит из мозаики отдельных блоков с архейским основанием, каждый из которых имеет собственную уникальную историю становления и развития. Объединение этих континентальных блоков в общую структуру кратона произошло в палеопротерозое (2.0-1.9 млрд лет), о чем свидетельствуют реликты палеопротерозойской ювенильной коры [Gladkochub et al., 2009; Donskaya, 2019]. Были опубликованы работы по обобщению ранее выполненных Sm-Nd, в том числе Hf, изотопных исследований по формированию континентальной коры ЦАСП [Condie, Kröner, 2013; Kröner et al., 2014, 2017]. В этих работах было показано, что основной объем (50 \%) коры был сформирован за счет древних коровых источников, 30 \% - смешанных (корово-мантийных) и только 20 \% занимает ювенильная кора. Все эти показатели близки к тем, которые были получены для восточной части складчатого пояса [Rytsk et al., 2007, 2011].

В последние годы нами дополнительно к уже имеющимся опубликованным данным были проанализированы разновозрастные магматические комплексы байкалид, каледонид и герцинид Забайкалья и Монголии с целью установления возможных связей островодужного и плюмового магматизма при формировании континентальной коры [Gordienko, 2018, 2019a, 2019b]. В результате на основе изучения известных моделей конвекции в астеносфере и мантии Земли, субдукционного и плюмового магматизма кайнозойских активных окраин западно-тихоокеанского и калифорнийского типа и собственных материалов многолетних исследований ЦАСП проанализирована взаимосвязь плейти плюмтектонических процессов при формировании неопротерозойских и эдиакарий-палеозойских островодужных систем и активных континентальных окраин (АКО) в зоне взаимодействия Сибирского континента и Палеоазиатского океана (ПАО). Было установлено, что субдукционный магматизм активных окраин ПАО невозможно отрывать от плюмового. Эти процессы сопряжены, взаимосвязаны и играли главную роль в истории формирования ЦАСП. В работе в результате анализа выполненных палеогеодинамических реконструкций неопротерозоя, эдиакария раннего и среднего палеозоя охарактеризовано 25 островодужных систем ПАО, с которыми связано формирование около 30 ареалов плюмового магматизма. Кроме того, в пределах активной окраины Сибирского континента описаны многочисленные поля разномасштабного проявления внутриплитного магматизма в рифтогенных структурах, не связанных с зонами субдукции, особенно на заключительном позднепалеозойском этапе. Сочетание фрагментов разнообразных островных дуг и ареалов плюмового магматизма указывает на то, что вся эта огромная неопротерозой-палеозойская область Центральной Азии, несомненно, была связана с деятельностью мантийных плюмов [Dobretsov et al., 2001; Kovalenko et al., 1999, 2004, 2006; Yarmolyuk, Kovalenko, 2003; Yarmolyuk et al., 1999, 2002; Kovach et al., 2011; Rytsk et al., 2011; Kuzmin, Yarmolyuk, 2014; и др.].

Вместе с тем многие вопросы геодинамического развития региона остаются слабоизученными и дискуссионными, особенно при определении роли, объемов и условий образования конкретных океанических, островодужных, аккреционно-коллизионных и внутриплитных структурно-формационных комплексов в формировании континентальной коры региона, так как они в основном решались без детальной геологической характеристики объектов исследований (фрагментов структур островных дуг и связанных с ними аккреционных призм, преддуговых и задуговых океанических бассейнов, ареалов коллизионного и плюмового магматизма). Чтобы восполнить этот пробел, нами были проведены дополнительные исследования по определению изотопно-геохронологического (U-Pb, Sm-Nd, $\mathrm{Ar}-\mathrm{Ar}$ ) и палеонтологического возраста магматических и осадочных пород, их источников, протолитов и условий формирования крупных полей вулканитов, ареалплутонов островодужно-океанического, аккреционноколлизионного и внутриплитного (плюмового) магматизма. Результаты этих исследований приведены в данной статье.

\section{2. МЕТОДЫ ИССЛЕДОВАНИЙ}

Наряду с палеогеодинамическими реконструкциями островных дуг, ареалов коллизионного и плюмового магматизма [Zonenshayn, Kuzmin, 1993] использовались методы структурно-геологического, петрологического, изотопно-геохимического исследования магматических комплексов, включающие в себя классический петрографический анализ и углубленное изучение вещественного состава пород как в полевых, так и в камеральных условиях. Лабораторные анализы U-Pb и $\mathrm{Ar}-\mathrm{Ar}$ возраста проводились в Центрах изотопных исследований ВСЕГЕИ, Института геологии и геохронологии докембрия РАН (г. Санкт-Петербург), Института геологии и минералогии СО РАН (г. Новосибирск) и Геологического института СО РАН (г. Улан-Удэ). При определении полученного относительного и абсолютного возраста пород использовались Международные стратиграфическая и геохронологическая шкалы [Gradstein et al., 2004; Gordienko, 2008].

Аналитические исследования изотопов Sm и Nd в основном проводились в ИГДД РАН (г. Санкт-Петербург), ГИН КНЦ РАН (г. Апатиты) и ИЗК СО РАН (г. Иркутск) 
по стандартной методике. При расчете величин $\varepsilon_{\mathrm{Nd}}(\mathrm{T})$ использованы современные значения для однородного хондритового резервуара (CHUR):

${ }^{143} \mathrm{Nd} /{ }^{144} \mathrm{Nd}=0.512628$ и ${ }^{147} \mathrm{Sm} /{ }^{144} \mathrm{Nd}=0.1967$.

$\mathrm{Nd}$ модельные возрасты $\mathrm{T}_{\mathrm{Nd}}(\mathrm{DM})$ вычислены в соответствии с моделью [Goldstein, Jacobsen, 1988], согласно которой изотопный состав $\mathrm{Nd}$ деплетированной мантии линейно эволюционировал с 4.55 млрд лет и имеет современное значение $\varepsilon_{\mathrm{Nd}}(0)$ :

$+10\left({ }^{143} \mathrm{Nd} /{ }^{144} \mathrm{Nd}=0.513151\right.$ и $\left.{ }^{147} \mathrm{Sm} /{ }^{144} \mathrm{Nd}=0.2136\right)$.

При расчете двухстадийных модельных возрастов $\mathrm{T}_{\mathrm{Nd}}(\mathrm{DM}-2 \mathrm{st})$ принята среднекоровая величина:

${ }^{147} \mathrm{Sm} /{ }^{144} \mathrm{Nd}=0.12$ [Taylor, McLennan, 1985].

Интерпретация $\mathrm{Nd}$ изотопных данных проведена по ранее разработанной методике [DePaolo et al., 1991; Kovach et al., 2000; Kovalenko et al., 2004; Rytsk et al., 2007; и др.].

В методическом плане в данной работе вначале будет рассмотрено геологическое строение карелид, байкалид, каледонид и герцинид Монголо-Забайкальского региона с использованием новой схемы тектонического районирования территории с выделением и характеристикой структурно-формационных комплексов (СФК) ${ }^{1}$ разного возраста, а также выполненных ранее палеогеодинамических реконструкций [Gordienko, 2019a]. В дальнейшем будут проанализированы и обсуждены результаты геохронологических и $\mathrm{Sm}-\mathrm{Nd}$ изотопных исследований океанических, островодужных, коллизионных и внутриплитных СФК, в заключении будут сформулированы выводы.

\section{3. ГЕОЛОГИЧЕСКОЕ СТРОЕНИЕ РЕГИОНА ИССЛЕДОВАНИЙ}

Монголо-Забайкальский регион, занимающий огромную территорию складчатого обрамления юга Сибирской платформы, имеет длительную историю геологического развития (см. рис. 1). Она охватывает промежуток времени от архея до мезозоя, продолжительностью около 3.5 млрд лет. В течение этого времени в исследуемом регионе был сформирован Сибирский кратон, останцы кратонных блоков (микроконтиненты), протерозойские и палеозойские складчатые области Центрально-Азиатского и Монголо-Охотского орогенных поясов, разновозрастные островодужные системы, аккреционно-коллизионные сооружения и области внутриплитного магматизма, связанные с мантийными плюмами [Kovalenko et al., 1996, 1999, 2006; Dobretsov, 2003, 2008, 2011a; Yarmolyuk, Degtyarov, 2019; Gordienko, 1987, 2006, 2019a].

Основу геологического строения Монголо-Забайкальского региона, составляющего восточную часть ЦАСП, определяют карельские (палеопротерозойские), байкальские (мезонеопротерозойские), каледонские (эдиакарий-раннепалеозойские) и герцинские (средневерхнепалеозойские) СФК (рис. 3).
Состав и условия образования этих комплексов, в целом, сыграли главную роль в формировании континентальной коры в пределах складчатого обрамления юга Сибирской платформы.

На начальной стадии формирования исследованного региона происходили грандиозные события, охватывающие архейскую эру (от 3.6 до 2.5 млрд лет). В это время был создан фундамент кратона, микроконтиненты и отдельные блоки разнообразных высокометаморфизованных пород по его периферии (Алдано-Становой, Шарыжалгайский, Гарганский), а также некоторые архейские структуры внутри ЦАСП (Байдарикский и др.). Индикаторами коллизионных событий в пределах Присаянского выступа юга Сибирского кратона являются мафит-ультрамафитовые породы Сарамтинского массива Шарыжалгайского блока и коллизионные гранитоиды китойского комплекса архея с U-Pb возрастом $2532 \pm 12$ млн лет, коровым источником $\varepsilon_{\mathrm{Nd}}(\mathrm{T})=-3.2$ и с $\mathrm{Nd}$ модельным возрастом протолита $\mathrm{T}_{\mathrm{Nd}}(\mathrm{DM})=3.2$ млрд лет [Gladkochub et al., 2005], а также Гарганского блока, сложенного ортогнейсами и породами тоналит-трондьемитовой ассоциации с U-Pb возрастом 2727 млн лет и $\mathrm{T}_{\mathrm{Nd}}(\mathrm{DM})=3.0-2.9$ млрд лет [Anisimova et al., 2009]. Байдарикский блок находится в Юго-Западной Монголии. Он образует ядро Дзабханского микроконтинента, представленного архей-палеопротерозойским байдарикским комплексом ортогнейсов, кристаллических сланцев и амфиболитов с возрастом 2848-2646 млн лет и $\mathrm{Nd}$ модельным возрастом протолита $\mathrm{T}_{\mathrm{Nd}}(\mathrm{DM})=3.3-2.9$ млрд лет [Kozakov et al., 2003, 2014].

\section{1. Карельские структурно-формационные комплексы}

Карельский (палеопротерозойский) этап развития Земли охватывает довольно длительный отрезок времени (2.50-1.60 млрд лет). Он тесно связан с предыдущим этапом развития - архейским (рис. 3). Это было время развития тектоники литосферных плит и тектоники плюмов [Kuzmin et al., 2018]. Земная кора в палеопротерозое стала уже более жесткой, способной к растрескиванию и формированию разнообразных плит и блоков. Продолжали существовать и вновь образовываться гранит-зеленокаменные пояса, глубинные разломы, рои даек, происходило массовое внедрение различных гранитоидов и проявление процессов метаморфизма, гранитизации и мигматизации. В грабенах и обширных впадинах на неоархейском фундаменте протоплатформ отлагались морские осадочные отложения значительной мощности, залегающие практически горизонтально (например, Удокан, до 10 км и более). На активных окраинах океанических бассейнов формировались зоны субдукции, проявлялась вулканическая деятельность и шло формирование гранитоидов островодужного и коллизионного типа [Gordienko, 2008]. Субдукционные процессы тесно связаны

${ }^{1}$ Под структурно-формационным комплексом (СФК) подразумевается совокупность тектонических структур, осадочных и магматических формаций, образовавшихся на определенном этапе развития территории, в определенной геодинамической обстановке и связанных между собой единством структурного плана и условий формирования. 


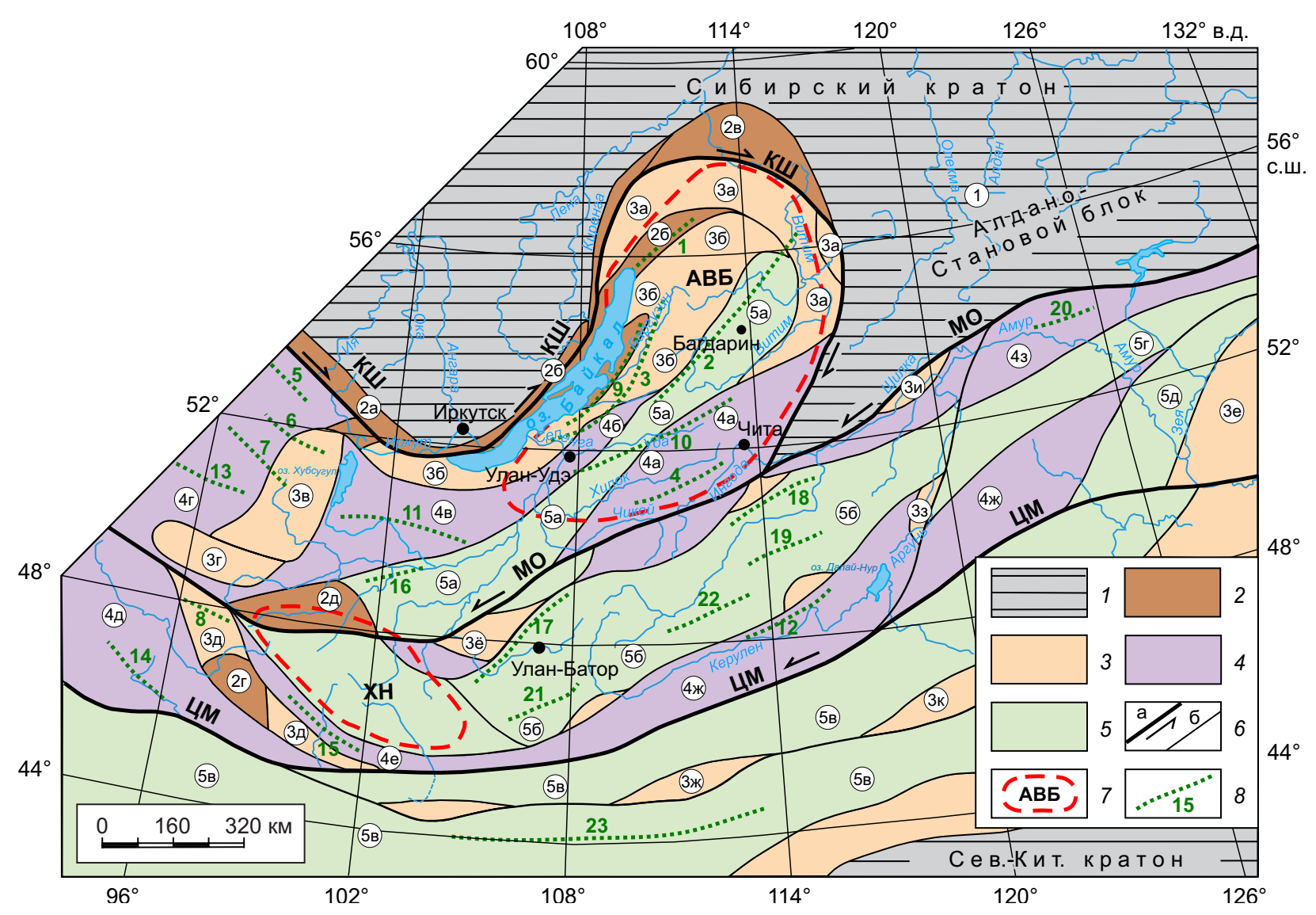

Рис. 3. Схема тектонического строения Монголо-Забайкальского региона (восточная часть Центрально-Азиатского складчатого пояса).

Тектонические структуры и слагающие их структурно-формационные комплексы (возраст, млрд лет): 1 - архейские (3.7-2.5): Северо-Китайский кратон и Сибирский кратон с Алдано-Становым блоком (1); 2 - карельские (палеопротерозой - 2.5-1.6), слагающие краевые перикратонные поднятия и блоки внутри складчатого пояса (цифры в кружках): Присаянское с Гарганской глыбой (2a), Прибайкальское с Кичерским блоком (2б), Байкало-Патомское (2в), Байдарикский (2г) и Тарбагатайский (2д) блоки; 3 - байкальские (мезонеопротерозой - 1.60-0.60), образующие структуры Байкало-Муйского пояса с Муйской глыбой (3а), Баргузино-Витимского бассейна с Хамардабанской (3б) и Уакит-Светлинской зоной (3б), Тувино-Монгольского (3в), Сангиленского (Зг), Сонгинского и Дзабханского (Зд), Буреинского (Зе) блоков и других более мелких массивов внутри складчатого пояса: Хархоринского (Зё), Среднегобийского (Зж), Ишагинского (3з), Пришилкинского (Зи), Уланульского (Зк) и др.); 4 - каледонские (эдиакарий - нижний палеозой - 0.60-0.42), слагающие структуры Удино-Витимской (4а), Турка-Курбинской (4б), Джидинской (4в), Восточно-Тувинской (4г), Озерной (4д), Баян-Хонгорской (4е), Керулен-Мамынской (4ж), Гонжинской (4з) зон; 5 - герцинские (средний - верхний палеозой - 0.42-0.25), образующие рифтогенные структуры Селенгино-Витимского (5а), Центрально-Монгольского (5б), Южно-Монгольского (5в) вулканоплутонических поясов, Туранской (5г) и Нора-Сухотинской (5д) аккреционных зон; 6 - а) крупные сдвиговые зоны и структурные швы (КШ - краевой шов Сибирского кратона, МО - Монголо-Охотский, ЦМ - Центрально-Монгольский), б) тектонические границы структурно-формационных зон и блоков; 7 - контуры Хангайского (ХН) и Ангаро-Витимского (АВБ) гранитоидных батолитов; 8 - фрагменты островных дуг и связанных с ними ареалов аккреционно-коллизионного магматизма (арабские цифры): (1-8) позднекарельские и байкальские: 1 - Нюрундуканская, 2 - Келянская, 3 - Метешихинская, 4 - Катаевская, 5 - Арзыбейская, 6 - Сархойская, 7 - Дунжугурская, 8 - Сонгинская (Холбонурская); (9-15) каледонские: 9 - Ангино-Таланчанская, 10 - Удино-Витимская (Еравнинская), 11 - Джидинская, 12 - Керуленская, 13 - Таннуольско-Хамсаринская, 14 - Озерная, 15 - Баянхонгорская; (16-23) герцинские: 16 - СевероХангайская, 17 - Северо-Хэнтейская, 18 - Северо-Агинская (Береинская), 19 - Уртуйская, 20 - Ольдойская, 21 - Адацагская, 22 - Норовлин-Ононская, 23 - Южно-Гобийская.

Fig. 3. Schematic tectonic map of the Mongolia-Transbaikalia region (eastern part of the Central Asian fold belt).

Tectonic structures and their composing structural-formation complexes (age, billion years): 1 - Archean (3.7-2.5): North China craton, and Siberian craton, including the Aldan-Stanovoy block (1); 2 - Karelian (Paleoproterozoic, 2.5-1.6), marginal pericratonic uplifts and blocks within the fold belt (numbers in circles): Cis-Sayan with the Gargan block (2a), Cis-Baikal with the Kichera block (2б), BaikalPatom (2в), Baidarik (2г) and Tarbagatai (2д) blocks; 3 - Baikal (Meso-Neoproterozoic, 1.60-0.60), structures of the Baikal-Muya belt with the Muya block (3а), Barguzin-Vitim basin with the Khamardaban (3б) and Uakit-Svetlaya zones (3б), Tuva-Mongolian (3в), Sangilen (Зг), Songin and Dzabkhan (Зд), Bureya (3e) blocks and other smaller massifs within the fold belt: Kharkhorin (3ë), Middle Gobi (Зж), Ishaga (3з), Cis-Shilka (Зи), Ulaan Uul (3k) etc.; 4 - Caledonian (Ediacaran - Lower Paleozoic, 0.60-0.42), structures of the zones: Uda-Vitim (4a), Turka-Kurba (4б), Dzhida (4в), East Tuva (4г), Lake (4д), Bayan-Khongor (4e), Kherlen-Mamyn (4ж), Gonzhin (43); 5 - Hercynian (Middle - Upper Paleozoic, 0.42-0.20), riftogenic structures of the Selenga-Vitim (5a), Central Mongolian (5б) and South Mongolian (5в) volcanic-plutonic belts, and the Turan (5г) and Nora-Sukhotin accretion zones; 6 - (a) large shear zones and 
structural joints (КШ - marginal suture of the Siberian craton, МО - Mongol-Okhotsk, ЦM - Central Mongolian), (б) tectonic boundaries of the structure forming zones and blocks; 7 - contours of the Khangai (XH) and Angara-Vitim (AВБ) granitoid batholiths; 8 - fragments of island arcs and related accretion-collision areas (Arabic numerals): (1-8) Late Karelian and Baikalian: 1 - Nyurundukan, 2 - Kelyana, 3 - Meteshikha, 4 - Kataevo, 5 - Arzybei, 6 - Sarkhoy, 7 - Dunzhugur, 8 - Songin (Kholbonur); (9-15) Caledonian: 9 - Anga-Talanchan, 10 - Uda-Vitim (Eravna), 11 - Dzhida, 12 - Kherlen, 13 - Tannuol-Khamsara, 14 - Lake zone, 15 - Bayarkhongor; (16-23) Hercinian: 16 - Northern Khangai, 17 - Nothern-Khentei, 18 - Northern Aga (Bereia), 19 - Urtui, 20 - Oldoi, 21 - Adatsag, 22 - Norovlin-Onon, 23 - South Gobi.

с зонами спрединга океанической коры, поэтому выделение океанической коры и надсубдукционных гранитоидов и вулканитов с возрастом 2.06-2.00 млрд лет в южных выступах Сибирского кратона имеет принципиальное значение при формировании континентальной коры в этом регионе [Donskaya, 2019]. Такие гранитоиды установлены в полосе между Шарыжалгайским и Бирюсинским блоками, а также в Голоустинском, Чуйском и Кутимском блоках Прибайкальского выступа. Они характеризуются положительными значениями $\varepsilon_{\mathrm{Nd}}(\mathrm{T})$ с палеопротерозойскими протолитами ювенильной коры [Gladkochub et al., 2001; Mazukabzov et al., 2006].

Во второй половине карельского этапа (2.0-1.9 млрд лет) произошло образование Сибирского кратона путем амальгамации разновозрастных террейнов различной геодинамической природы. В это время произошло массовое внедрение коллизионных гранитоидов, образование гранитогнейсовых поясов, включающих метаморфизм, гранитизацию и интенсивные деформации с возрастом 1.95-1.88 и 1.88-1.84 млрд лет, что способствовало окончательному формированию и вхождению Сибирского кратона в структуру суперконтинента Колумбия и в дальнейшем затуханию эндогенных процессов в течение почти одного миллиарда лет (1.70-0.75) в связи с образованием крупного «транспротерозойского суперконтинента», включающего Сибирь, Лавразию и другие континенты [Gladkochub et al., 2009, 2010].

В пределах Монголо-Забайкальского региона к карельскому этапу относится образование краевых перикратонных поднятий (Присаянское, Прибайкальское, Байкало-Патомское, Тарбагатайский и Дзабханский микроконтиненты в Монголии). Эндогенная активность в палеопротерозое в пределах Присаянского выступа юга Сибирского кратона связана с процессами субдукции океанической коры и формированием надсубдукционных гранитоидов и габбро-пироксенитов с бонинитовой спецификой Булунского массива с возрастом $1880 \pm 90$ млн лет ( $\mathrm{T}_{\mathrm{Nd}} \mathrm{DM}=2.9$ млрд лет) [Gladkochub et al., 2001; Gladkochub, 2004]. Они сопоставляются с кодарским гранодиорит-гранитным комплексом Алдано-Станового блока с возрастом Кодарского массива (1877£4 млн лет) [Larin et al., 2000; Donskaya, 2019].

В пределах Прибайкальского выступа, охватывающего западное и частично восточное побережье озера Байкал, выделяются палеопротерозойские осадочно-метаморфические и магматические комплексы в полосе от Приольхонья до Кичерского блока включительно. Так, по данным [Dobretsov et al., 1989b] на восточной части побережья озера Байкал внизу разреза залегает черногривенская свита, в состав которой входят двупироксеновые эклогитоподобные гранулиты, гранатовые амфиболиты, габбро-амфиболиты, метагаббро, габбро-анортозиты. Выше залегают плагиоклазово-амфиболовая и мигматит-плагиогранитная с амфиболитами толщи. U-Pb возраст по цирконам черногривенской свиты позднеархейский - 3086 млн лет [Rudenko et al., 2010]. Верхняя часть разреза этого района сложена карбонатно-гнейсовым комплексом (максимихинская, крестовская, катковская свиты) общей мощностью около 3000 м. Эти отложения из-за плохой обнаженности изучены слабо. Не исключено, что часть названных свит принадлежит каледонской Ангино-Таланчанской островной дуге. На северо-западном и северном побережье озера Байкал подобные отложения входят в состав раннедокембрийского Кичерского блока, который охарактеризован нами далее в составе байкалид западной части Байкало-Муйского блока.

Байкало-Патомское поднятие образует неоархейпалеопротерозойскую пассивную окраину Сибирского кратона. Здесь выделяются мощные интенсивно метаморфизованные толщи патомского комплекса, пронизанные разнообразными коллизионными гранитоидами с возрастом от 1906-1890 до 1880-1838 млн лет [Rytsk et al., 2011; Donskaya, 2019]. Эти структуры Байкало-Патомского бассейна хорошо фиксируются геолого-геофизическими исследованиями [Bulgatov, 1988, 2015].

В целом, карельский этап был периодом стабилизации обширных участков подвижных поясов и формирования суперконтинентов и платформенных областей. В результате позднекарельских аккреционно-коллизионных процессов произошло слияние протоорогенных областей с протоплатформенными, образовались платформенные структуры и началось формирование типично платформенного чехла.

\section{2. Байкальские структурно-формационные комплексы}

Байкальский (мезонеопротерозой) этап охватывает продолжительный отрезок времени около 1000 млн лет (от 1600 до 0.600 млн лет). Это было время существования и распада суперконтинента Родиния и возникновения планетарных подвижных поясов на океанической коре. В период от 1100 до 750 млн лет усилились процессы рифтогенного мантийного магматизма, произошло формирование крупных дайковых поясов на окраинах Сибири и Лавразии. Эти процессы привели к расколу Родинии, формированию ПАО и других океанических бассейнов, обособлению двух крупных суперконтинентов - Лавразия и Гондвана, а также целого ряда континентов (Сибирь, Северный и Южный 
Китай, Тарим, Казахстан и др.) В конце неопротерозоя проявилась байкальская складчатость, приведшая к широкому развитию коллизионных процессов и формированию складчатой системы байкалид [Sklyarov et al., 2000; Kuzmin, Yarmolyuk, 2014; Maruyama et al., 2014; Kheraskova et al., 2014].

В пределах Монголо-Забайкальского региона к байкальскому этапу относится образование целого ряда структур мезонеопротерозойского возраста: БайкалоМуйского пояса с Кичерским зоной и Муйской глыбой, Баргузино-Витимского океанического бассейна, Тувино-Монгольского, Сонгинского, Буреинского и других более мелких массивов (Хархоринский, Среднегобийский, Ишагинский, Уланульский и др.) и турбидитовых бассейнов внутри складчатого пояса. Названные пояca, бассейны, зоны и массивы выступают в настоящее время в виде микроконтинентов или отдельных докембрийских блоков среди покровно-складчатых структур каледонид и герцинид (рис. 3). Среди них наиболее крупными выступами мезонеопротерозойской континентальной коры являются Тувино-Монгольский массив с Сангиленским блоком и Сонгино-Тарбагатайский массив. В их пределах обнаружены блоки с ранне- и позднедокембрийским кристаллическим фундаментом, а также многочисленные фрагменты островодужного, аккреционно-коллизионного и плюмового магматизма [Kozakov et al., 2003; Yarmolyuk et al., 2017; Yarmolyuk, Degtyarev, 2019].

Одновременно с формированием складчатой структуры байкалид происходила интенсивная вулканическая деятельность с образованием энсиматических и энсиалических островных дуг и ареалов внутриплитного магматизма. Кроме неопротерозойских, здесь существовали более древние дуги с возрастом более 1 млрд лет (Нюрундуканская, Дунжугурская, Арзыбейская и др.), которые не были связаны с развитием ПАО и формировались на окраинах суперконтинента Родиния и за его пределами и после его распада в неопротерозое (850-800 млн лет) участвовали в формировании континентальной коры байкалид по периферии Сибири [Kheraskova et al., 2010, 2014; Gordienko, Metelkin, 2016].

Байкало-Муйский островодужный пояс занимает значительную территорию Северного Прибайкалья и Средневитимской горной страны. Он образует крупную дугообразную структуру шириной в центральной части около 200 км и протяженностью свыше 600 км. На севере пояс граничит по системе разломов сдвигового типа с Байкало-Патомской пассивной окраиной Сибирского кратона, с юга к нему примыкают фрагменты Баргузино-Витимского океанического бассейна с неопротерозойскими островными дугами и окружающими их структурами. Байкало-Муйский пояс сложен сочетанием разновозрастных покровно-складчатых зон, выполняющих рифтогенные структуры с океанической корой, островодужным и внутриплитным магматизмом [Konnikov et al., 1999; Tsygankov, 2005; Rytsk et al., 2007, 2011; Bulgatov, 2015]. Более половины площади пояса занимают гранитоиды Ангаро-Витимского батолита позднего палеозоя. Среди структур Байкало-Муйского пояса выделяются Кичерская, Парамская, Каралон-Мамаканская и Анамакит-Муйская зоны [Rytsk et al., 2007].

Кичерская зона сложена океаническими и островодужными комплексами мощностью свыше 2000 м, относящимися к нюрундуканской свите. Среди пород свиты выделяются двупироксеновые, пироксен-амфиболовые сланцы, пироксеновые мигматиты, эндербиты и чарнокиты. Двупироксеновые сланцы по геохимическому составу соответствуют базальтам островных дуг и океанических островов [Konnikov et al., 1999]. По породам гранулит-эндербитового комплекса образовались амфиболиты и гранатовые амфиболиты, которые ассоциируют здесь с серпентинизированными гарцбургитами, амфиболизированными габброидами и плагиогранитами Нюрундуканского ультрамафит-мафитового массива. Все эти породы относятся к супрасубдукционным офиолитовым образованиям задуговых бассейнов [Dobretsov, 1983; Tsygankov, 2005].

Парамская зона сложена одноименным гипербазитовым массивом и обрамляющими его океанической сланцево-кремнисто-базитовой и островодужной кремнисто-терригенно-туфогенно-андезит-дацит-риолитовой ассоциациями. В нижней части разреза распространены глубоководные кремнисто-хлоритовые и кремнистые сланцы с горизонтами метабазальтов и ортоамфиболитов. Эти породы вмещают линзовидные тела метагаббро и пиллоу-лавы низкотитанистых базальтов E-MORB типа. Каралон-Мамаканская зона сложена метабазальтами E-MORB типа в ассоциации с углеродисто-кремнистыми сланцами и яшмоидами. На них с несогласием залегают породы островодужного комплекса метабазальтов, андезитов, дацитов, их туфов и вулканокластики. Океанические и островодужные образования Парамской и Каралон-Мамаканской зон входят в состав Келянской островодужной системы [Gordienko, 2006, 2019a; Tsygankov, 2005; Bulgatov, 2015].

Анамакит-Муйская зона охватывает центральную и западную часть Байкало-Муйского пояса. В нее входят ряд структур (Светлинская, Янская, Бамбуйско-Олиндинская, Катеро-Уакитская и др.), расположенных на северо-восточном побережье озера Байкал. Эти структуры сложены разновозрастными метаморфизованными сланцево-терригенными толщами с прослоями основных и кислых вулканитов островодужного типа с возрастом от 825 до 815 млн лет (кедровская, буромская, усть-келянская, жанокская и др.). С ними ассоциируют породы габбро-диорит-плагиогранитного муйского комплекса (812 млн лет), массивы калиевых гранитоидов бамбукойского комплекса (735 млн лет) и высокотитанистых габбро с возрастом 733 и 774 млн лет [Tsygankov, 2005; Rytsk et al., 2011; Bulgatov, 2015].

Особое место в структуре Байкало-Муйского пояса занимает Муйская глыба. По геолого-сейсмическим данным она представляет крупную пластину, наклоненную на северо-восток и уходящую на глубину 20 км [Bulgatov, 1988; Bulgatov et al., 2004]. Условно палеопротерозойский возраст высокометаморфизованных отложений 
Муйской глыбы представлен киндиканской толщей, сложенной амфиболовыми, гранат-амфиболовыми гнейсами и сланцами. Среди этих пород наблюдаются линзовидные тела гранатовых ультрабазитов и эклогитов. В более поздней илеирской толще среди гнейсов и сланцев также обнаружены отдельные тела и цепочки эклогитов c Sm-Nd возрастом 653 млн лет. Их формирование связывается с субдукционными процессами [Dobretsov et al., 1989b; Shatsky et al., 1996].

В Западном Забайкалье в позднебайкальский этап активно формировался Баргузино-Витимский океанический бассейн и сопряженные с ним Келянская и Метешихинская островодужные системы. В пределах Баргузино-Витимского океанического бассейна распространены неопротерозойские сложнодислоцированные осадочно-метаморфические толщи, выделяемые в составе Баргузинского и Верхневитимского (Икатского) турбидитовых террейнов, мощностью 10-12 км. Среди осадочно-вулканогенных толщ этих террейнов повсеместно встречаются глубоководные кремнистые отложения и фрагменты офиолитов, сложенных серпентинитами, метагабброидами и метабазальтами типа E-MORB и OIB c U-Pb возрастом 971-908 млн лет, указывающие на океаническую природу БаргузиноВитимского бассейна [Nekrasov et al., 2007; Gordienko et al., 2009].

Таким образом, к концу позднебайкальского этапа (630-610 млн лет) завершилось формирование островных дуг, преддуговых, междуговых и задуговых бассейнов, микроконтинентов и причленение их к окраине Сибирского кратона. В результате образовался протяженный Саяно-Монголо-Забайкальский складчатый пояс байкалид.

\section{3. Каледонские структурно-формационные комплексы}

В формировании каледонской континентальной коры ЦАСП выделяется два периода: раннекаледонский (эдиакарий - кембрий) и позднекаледонский (ордовик - силур). После байкальской складчатости, главные фазы которой проявились на границе неопротерозоя и эдиакария, многие районы Забайкалья и Монголии оказались приподнятыми и стали областями сноса. Продукты разрушения байкалид накапливались в пограничных с ними прогибах. В эдиакарии - раннем кембрии началась крупная раннепалеозойская трансгрессия, особенно широко проявившаяся на Сибирской платформе.

В эдиакарий-кембрийских океанических, островодужных и окраинноморских структурах, связанных с развитием ПАО, продолжалось интенсивное формирование осадочных и вулканогенных образований, где сформировались целые системы островных дуг и срединноокеанических хребтов (COX). Тектоническая история этих структур напрямую связана с историей заложения, развития и закрытия ПАО. По данным [Dobretsov, 2003], активное развитие океана происходило во вторую стадию (630-540 млн лет), то есть в эдиакарии - раннем кембрии. В это время формировались спрединговые зоны СОХ, энсиматические (примитивные) и энсиалические (зрелые) островные дуги с протяженными зонами субдукции, преддуговые, задуговые бассейны и междуговые спрединговые окраинные моря. Главным в истории ранних каледонид считается рубеж 570 млн лет. Именно к этому рубежу приурочено формирование большинства офиолитовых зон по сибирской окраине ПАО [Yarmolyuk et al., 2006; Gordienko, Metelkin, 2016].

В пределах Монголо-Забайкальского региона раннекаледонские покровно-складчатые структуры занимают значительные площади (см. рис. 2, 3; рис. 4). Они образуют целый ряд стуктурно-формационных зон в Западном и Центральном Забайкалье (Турка-Курбинская, Удино-Витимская, Джидинская, Чикой-Ингодинская), в пределах восточной части Алтае-Саянской области и Монголии (Восточно-Тувинская, Озерная, БаянХонгорская, Керулен-Мамынская). Эти зоны включают в себя ряд эдиакарий-раннекаледонских островных дуг (Таннуольско-Хамсаринская, Джидинская, Ангино-Таланчанская, Удино-Витимская и др.), а также окраинноморских океанических бассейнов, связанных с развитием ПАО.

К концу кембрия в подвижных поясах Палеоазиатского океана нарастает тенденция столкновения вулканических дуг и окраинных морей с Сибирским континентом. Она особенно заметна в Алтае-Саяно-МонголоЗабайкальской области ЦАСП, восточная часть которого в эту эпоху пережила мощный импульс латерального сжатия, приведшего к складчато-надвиговым деформациям и к некоторому разрастанию континентальной коры на периферии Тувино-Монгольского, Дзабханского и Центрально-Монгольского микроконтинентов в связи со столкновением вулканических дуг с этими микроконтинентами.

В итоге по всему складчатому обрамлению севера (в древних координатах) Сибирского кратона возник пояс коллизионных структур, которые совместно с отложениями шельфа и континентального склона сформировали обширную континентальную окраину ПАО. Это была своеобразная окраина, так как во второй половине ордовика и особенно в силуре в некоторых районах Алтае-Саянской области, Монголии и Забайкалья продолжали формироваться островные дуги (например, Салаирская, Улан-Ундурская, Ангино-Таланчанская, Ульзутуйская), зоны рифтогенеза с образованием осадочных бассейнов со значительным вулканогенным наполнением (например, Харагольский гемипелагический прогиб с пиллоу-лавами в Северной Монголии). Эти процессы были связаны с заложением МонголоОхотского океана и в последующем с формированием Монголо-Охотского складчатого пояса [Gordienko et al., 2012d, 2018b, 2019b].

\section{4. Герцинские структурно-формационные комплексы}

Герцинские СФК с возрастом от 420 до 250 млн лет проявились в исследованном регионе в два этапа общей 
продолжительностью более 170 млн лет: раннегерцинский (девон - ранний карбон) и позднегерцинский (средний карбон - пермь).

В раннегерцинский этап увеличившийся в размерах Сибирский континент находился в Северном полушарии. Согласно палеомагнитным данным, Сибирский кратон в девонское время был развернут относительно современного положения на $180^{\circ}$, при этом его нынешняя южная окраина располагалась на широте 50-60 [Kravchinsky, Sorokin, 2001]. К этому времени Палеоазиатский океан трансформировался в океан Палеотетис [Zonenshayn et al., 1990]. По южной (в современных координатах) окраине Сибирского континента существовали следующие геодинамические обстановки: 1) обширная Саяно-Забайкальская активная континентальная окраина с рифтогенным и коллизионным магматизмом, а также мелководным морским осадконакоплением; 2) Хангай-Хэнтэй-Даурская система окраинных морей и окружающих их островных дуг Монголо-Охотского океанического бассейна; 3) Южно-Монгольская островодужно-океаническая система северной окраины Палеотетиса (Солонкерская зона), которая, по-видимому, была удалена от Сибирского континента на значительное (свыше 2000 км) расстояние, однако по насыщенности продуктов вулканической и плутонической деятельности среднего и верхнего палеозоя не уступала названным выше геодинамическим обстановкам [Yarmolyuk, Kovalenko, 1982, 1991; Kozlovsky et al., 2007; Gordienko, 1987, 2006, 2019a].

В среднем - верхнем палеозое по всей южной окраине Сибирского континента в условиях рассеянного рифтогенеза и разнонаправленной субдукции проявились масштабные тектономагматические процессы, которые привели к образованию на окраине континента герцинских рифтогенных (внутриплитных) структур минусинского типа, а также наложенных прогибов в

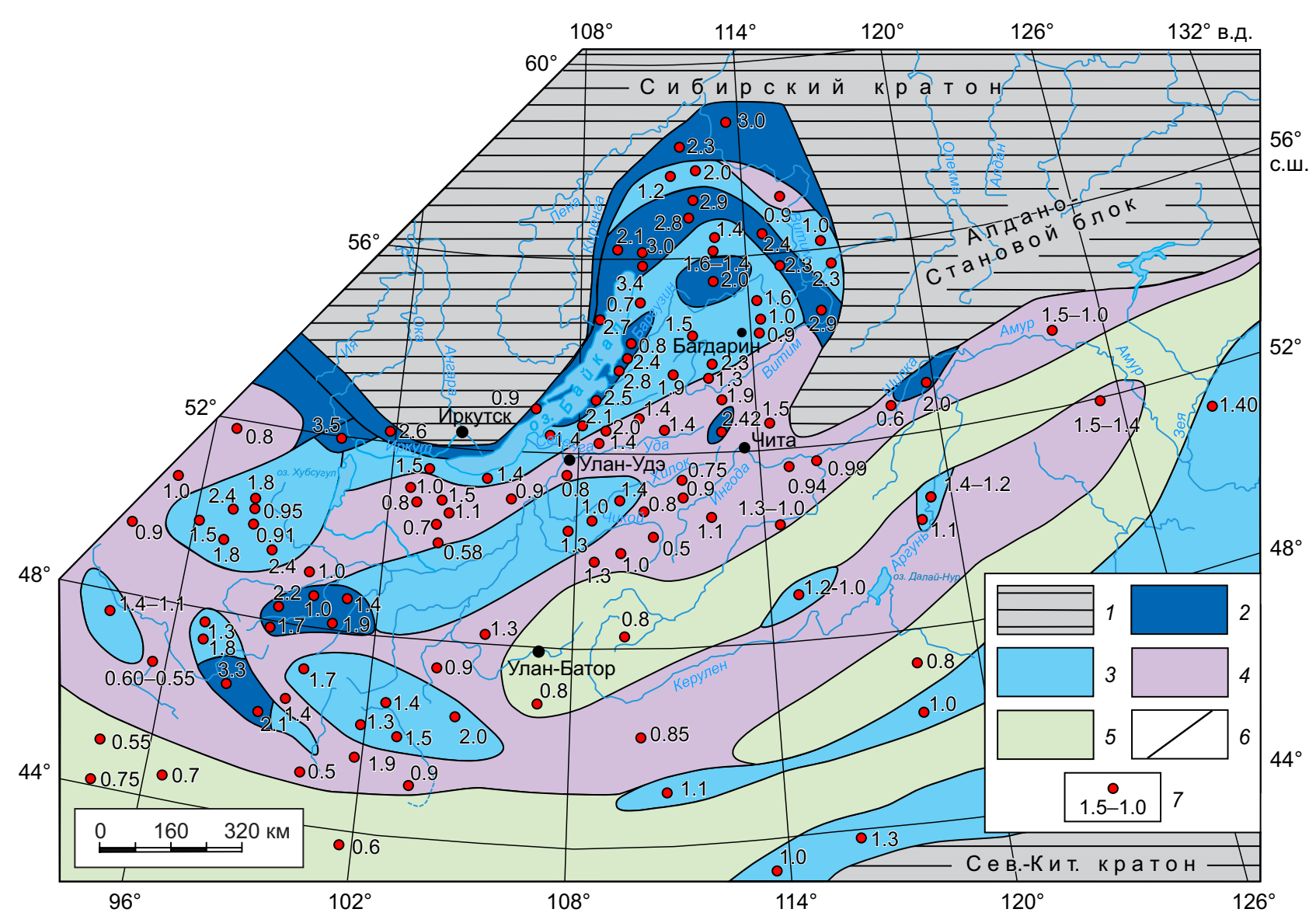

Рис. 4. Схема расположения изотопных провинций континентальной коры Монголо-Забайкальского региона в зависимости от Nd модельного возраста $\mathrm{T}_{\mathrm{Nd}}(\mathrm{DM})$ и $_{\mathrm{Nd}}(\mathrm{DM}-2 \mathrm{st})$ их формирования (млрд лет).

1 - архейская (>2.5); 2 - карельская (неоархей-палеопротерозойская - 2.6-1.6); 3 - байкальская (мезонеопротерозойская 1.6-0.9); 4- каледонская (эдиакарий-раннепалеозойская - 0.9-0.5); 5 - герцинская (средне- и верхнепалеозойская - 0.5-0.3); 6 - границы разновозрастных ареалов изотопных провинций континентальной коры; 7 - цифры Nd модельного возраста коры по авторским и другим опубликованным данным (Приложение 1).

Fig.4. Schematic map showing the isotope provinces of continental crust in the Mongolia-Transbaikalia region according to the Nd model ages of their formation. $\mathrm{T}_{\mathrm{Nd}}(\mathrm{DM})$ and $\mathrm{T}_{\mathrm{Nd}}(\mathrm{DM}-2 \mathrm{st})$, billion years.

1 - Archean (>2.5); 2 - Karelian (Neoarchean - Paleoproterozoic, 2.6-1.6); 3 - Baikalian (Meso-Neoproterozoic, 1.6-0.9); 4 - Caledonian (Ediacaran - Early Paleozoic, 0.9-0.5); 5 - Hercinian (Middle Upper Paleozoic, 0.5-0.3); 6 - boundaries of heterochronous areas of the isotope provinces; 7 - Nd model ages (the author's and other published data, see Appendix 1). 
Забайкалье (Урминский, Багдаринский, Уакитский и некоторые другие), представляющих собой фрагменты единого крупного палеобассейна позднего девона среднего карбона [Gordienko et al., 2010; Ruzhentsev et al., 2012; Minina et al., 2016]. Последний был связан с формированием Хэнтэй-Даурско-Агинской системы окраинных морей и островных дуг Монголо-Охотского океанического бассейна [Gordienko, 2019a]. Этот бассейн с юго-востока (в современных координатах) через систему островных дуг и задуговых морей примыкал непосредственно к активной окраине Сибирского континента и по длине вполне был соизмерим с ее юго-восточной частью. По существу, бассейн состоял из цепочки задуговых окраинных морей (Хангайское, Хэнтэйское, Даурское, Агинское, Ольдойское), разделенных поперечными поднятиями. Система окраинных морей была окружена островными дугами (Северо-Хангайская, Северо-Хэнтэйская, Северо-Агинская, Ольдойская и др.), в которых в течение девона, раннего карбона проявился островодужный и рифтогенный плюмовый магматизм (в вулканической и интрузивной форме) и образовались задуговые мелководные морские бассейны с бореальной фауной [Sorokin et al., 2015; Yarmolyuk et al., 2018; Gordienko, 2019a].

Во внутренних частях окраинных спрединговых морей (Хангайское, Хэнтэйское, Даурское, Агинское и др.) происходило излияние толеитовых базальтов и внедрение тел диабазов, габбро-диабазов. В Агинском прогибе обнаружены базальты типа E-MORB и линзы серпентинитов - фрагментов океанической коры. Базальты типа N-MORB обнаружены нами в Даурском прогибе Boсточного Забайкалья и в Улан-Баторском бассейне Монголии. Океаническими базальтами (пиллоу-лавы) насыщены в основном низы девон-раннекаменноугольных разрезов окраинных морей, где они слагают симаунты (гайоты) и ассоциируют с яшмами, кремнисто-граувакковыми (турбидитовыми) и карбонатными отложениями. Выше по разрезу базальты встречаются в меньшем количестве. Все это указывает на то, что обстановка растяжения была максимальной в начале девона, а затем затухала к концу карбона. Появление в пределах Монголо-Охотского океанического бассейна океанических плато (гайотов), сложенных субщелочными базальтами OIB и «шапками» известняков с девонскими конодонтами, образование радиоляриевых кремней, гиалокластитов, излияние субщелочных базальтов, отсутствие среди кремнистых отложений терригенного материала указывают на широкое раскрытие и длительное существование девонского океанического бассейна и его связь с плюмовым магматизмом [Ruppen et al., 2014; Gordienko et al., 2018b].

Позднепалеозойский внутриплитный магматизм на активной окраине континента наиболее ярко проявился в Забайкалье, Северной, Центральной и Южной Монголии. Магматические комплексы этого времени образуют здесь два крупных гранитоидных батолита (Ангаро-Витимский и Хангайский) и ряд протяженных вулканоплутонических поясов рифтогенного типа
(Селенгино-Витимский, Центрально-Монгольский и Южно-Монгольский), различающихся по составу и набору слагающих их пород, структурному положению и истории развития [Gordienko, 1987, 2019a; Yarmolyuk, Kovalenko, 1982, 1991; Yarmolyuk et al., 1999, 2016; Kozlovsky et al., 2007; Tsygankov et al., 2010].

\section{4. ИНТЕРПРЕТАЦИЯ РЕЗУЛЬТАТОВ ГЕОХРОНОЛОГИЧЕСКИХ И SM-ND ИЗОТОПНЫХ ИССЛЕДОВАНИЙ МАГМАТИЧЕСКИХ И МЕТАОСАДОЧНЫХ ПОРОД МОНГОЛО-ЗАБАЙКАЛЬСКОГО РЕГИОНА}

Сложность строения, разнообразие источников и форм проявления древнего магматизма региона создают серьезные проблемы при его изучении. Большинство глубинных магм подвергаются в разной степени контаминированию коровым материалом, метасоматозу при кристаллизации в промежуточных очагах и при прохождении их к поверхности, поэтому трудно отделить геохимические и изотопные характеристики источников магм от последствий более поздних процессов. В решении этих проблем могут в какой-то степени помочь разработанные нами палеогеодинамические реконструкции островодужных систем [Gordienko, 2019а], которые опираются, прежде всего, на палеомагнитные данные и сравнительный анализ петрологогеохимического состава современных и древних субдукционных комплексов, что позволяет распознавать геодинамические условия формирования реконструируемых систем [Yarmolyuk et al., 2006; Gordienko, 2006, 2008, 2019a].

В данном разделе приводится анализ результатов геохронологических и $\mathrm{Sm}-\mathrm{Nd}$ изотопных исследований магматических и некоторых метаосадочных пород Монголо-Забайкальского региона, которые приведены в таблице Sm-Nd изотопных исследований, составленной на основе опубликованных данных и дополнительных неопубликованных авторских материалов (Приложение 1).

Представленные в таблице материалы вариаций величин $\varepsilon_{\mathrm{Nd}}(\mathrm{T}), \mathrm{T}_{\mathrm{Nd}}(\mathrm{DM})$ и $\mathrm{T}_{\mathrm{Nd}}(\mathrm{DM}-2 \mathrm{st}) \mathrm{Sm}-\mathrm{Nd}$ изотопных исследований СФК региона позволили выделить разновозрастные изотопные провинции, которые приведены на составленной схеме расположения изотопных провинций континентальной коры Монголо-Забайкальского региона в зависимости от модельного возраста их формирования (рис. 4).

При этом, с учетом того, что реальный возраст СФК региона (см. рис. 3) и $\mathrm{Nd}$ модельный возраст коры их формирования (рис. 4) не совпадают, нами принято возрастное расчленение изотопных провинций коры региона, согласно [Kovalenko et al., 1999, 2004, 2006] для Центрально-Азиатского складчатого пояса (см. рис. 2).

В целях дальнейшей интерпретации материалов нами составлена диаграмма зависимости величины $\varepsilon_{\text {Nd }}(T)$ магматических и некоторых осадочных комплексов пород от их возраста и размещения в изотопных провинциях континентальной коры разного возраста 
(рис. 5), а также показанная ниже (раздел 5), диаграмма размещения $\mathrm{Nd}$ модельных возрастов $\mathrm{T}_{\mathrm{Nd}}(\mathrm{DM})$ по отношению к возрасту магматических и осадочных пород островодужного, коллизионного и внутриплитного типа в изотопных провинциях Монголо-Забайкальского региона.

Рассмотрим на основе анализа структурно-геологического строения региона, результатов геохронологических и Sm-Nd изотопных исследований механизмы формирования континентальной коры в структурах различной геодинамической природы.

\section{1. Роль островодужно-океанических процессов в формировании континентальной коры}

Зоны субдукции и связанный с ними островодужный магматизм являются важнейшими структурными элементами окраин как современных, так и древних океанов [Dobretsov, 2010, 2020]. При изучении механизма движения литосферных плит была установлена конвекция в верхней мантии и астеносфере как главная движущая сила тектоники плит. Важнейшими ее следствиями, с одной стороны, является спрединг и рождение океанической коры в срединно-океанических

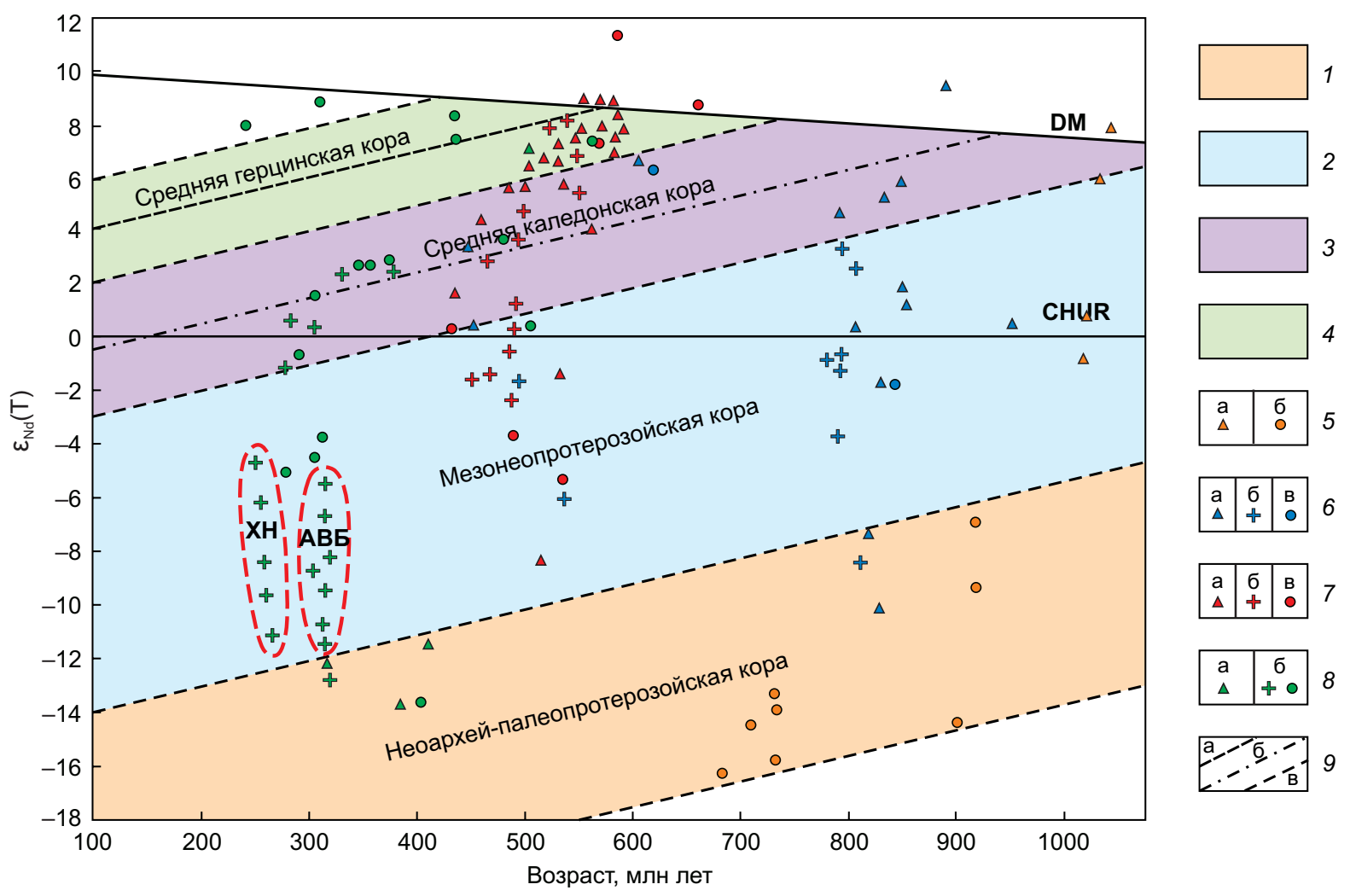

Рис. 5. Зависимость величины источников $\varepsilon_{\text {Nd }}($ T) магматических и осадочных комплексов пород от их возраста и размещения в изотопных провинциях континентальной коры разного возраста Монголо-Забайкальского региона.

1-4 - области эволюции изотопного состава Nd в континентальной коре следующих возрастов: 1 - карельского (верхний архей - палеопротерозой), 2 - байкальского (мезонеопротерозой), 3 - каледонского (эдиакарий - ранний палеозой), 4 - герцинского (средний - верхний палеозой); 5-8 - табличные значения содержаний $\left(\varepsilon_{\mathrm{Nd}}(\mathrm{T})-\right.$ возраст) в магматических и осадочных комплексах пород различной геодинамической природы (Приложение 1): 5 - в карелидах (а - островодужные, б - внутриплитные), 6 - в байкалидах (а - островодужные, б - коллизионные, в - внутриплитные), 7 - в каледонидах (а - островодужные, б - коллизионные, в - внутриплитные), 8 - в герцинидах (а - островодужные, б - внутриплитные: плутонические и вулканические); 9 - тренды эволюции среднего состава континентальной коры в каледонских (а) и герцинских (б) изотопных провинциях с зонами влияния (в) [Kovalenko et al., 1999, 2006]. DM - деплетированная мантия, CHUR - неистощенный (хондритовый) мантийный резервуар. Красным пунктиром показано расположение герцинских внутриплитных гранитоидных батолитов (АВБ - Ангаро-Витимского и ХН - Хангайского) в изотопных провинциях мезонеопротерозойской коры.

Fig. 5. Dependence of $\varepsilon_{\mathrm{Nd}}(\mathrm{T})$ values of igneous and sedimentary rock complexes on their ages and locations in the heterochronous isotope provinces of continental crust in the Mongolia-Transbaikalia region.

1-4 - areas of the Nd isotopic composition evolution in the continental crust of the following ages: 1 - Karelian (Upper Archean - Paleoproterozoic), 2 - Baikal (Meso-Neoproterozoic), 3 - Caledonian (Ediacaran - Early Paleozoic), 4 - Hercynian (Middle - Upper Paleozoic); $5-8$-values of $\left(\varepsilon_{\mathrm{Nd}}(\mathrm{T})\right.$ contents - age) in igneous and sedimentary rock complexes of various geodynamic nature (see Appendix 1) for: 5 - Karelides ( $\mathrm{a}$ - island arc, 6 - intraplate), 6 - Baikalides (a - island arc, 6 - collision, в - intraplate), 7 - Caledonides (a - island arc, b - collision, B - intraplate), 8 - Hercynides ( $\mathrm{a}$ - island-arc, 6 - intraplate: plutonic and volcanic); 9 - evolution trends of the average composition of continental crust in the Caledonian (a) and Hercynian (б) isotope provinces with the zones of influence (в) [Kovalenko et al., 1999, 2006]. DM - depleted mantle, CHUR - undepleted (chondritic) mantle reservoir. Red dashed lines -locations of the Hercynian intraplate granitoid batholiths ( $\mathrm{AB}$ - Angara-Vitim, XH - Khangai) in the isotope provinces of the Meso-Neoproterozoic crust. 
хребтах, с другой - субдукция океанических плит, их частичное переплавление, эклогитизация и образование новой континентальной коры за счет океанической. Согласно исследованиям [Kovalenko et al., 1996, 1999], основным источником океанической коры в складчатых областях является деплетированная мантия (DM), из которой выплавляются базиты офиолитовых комплексов океанической коры. Установлено, что максимальные значения $\varepsilon_{\text {Nd }}(\mathrm{T})$ для изученных массивов офиолитов Монголии и Забайкалья вполне удовлетворительно совпадают с линией изотопной эволюции DM. Установлено, что изотопный состав каледонских островодужно-океанических вулканитов в пределах ЦАСП отвечает $\mathrm{Nd}$ модельным изотопным возрастам и соответствует времени образования этих пород в островодужной системе, в то время как осадочные породы, образованные в результате размыва и сноса с более древних поднятий или окраин когда-то существовавших бассейнов, имеют более древние $\mathrm{Nd}$ модельные возрасты и соответственно удревняют общий Nd модельный изотопный возраст созданной островодужной коры.

Вся сложность в определении истинных масштабов океанического и островодужного магматизма, а также осадконакопления при формировании структур континентальной коры на территории Монголо-Забайкальского региона возникает из-за того, что в древних (протерозой-палеозойских) СФК эти образования существуют в виде отдельных фрагментов среди покровноскладчатых структур и часто бывает трудно объединить их в единые островодужные системы с участием океанических комплексов, с которыми они обнаруживают генетические связи.

Представителями мезонеопротерозойских островодужных систем в пределах Монголо-Забайкальского региона являются Нюрундуканская, Дунжугурская и Арзыбейская островные дуги (рис. 6).

Фрагменты крупной Нюрундуканской дуги выделены в Кичерском блоке Северного Прибайкалья. Кичерская зона состоит из нескольких тектонических пластин. Нижняя пластина, мощностью более 2 км, сложена нюрундуканской толщей метабазальтов, метадолеритов, габбро-диабазов с U-Pb и Sm-Nd возрастом $1050 \pm 160$ и $1035 \pm 92$ млн лет соответственно [Rytsk et al., 2001]. При этом величины $\varepsilon_{\mathrm{Nd}}(\mathrm{T})$ составляют от +5.6 до +7.9, что приближает их к источникам обогащенной DM (Приложение 1; см. рис. 4, 5).

$\mathrm{Nd}$ модельные возрасты пород $\left(\mathrm{T}_{\mathrm{Nd}}(\mathrm{DM})=2320\right.$ и $\mathrm{T}_{\mathrm{Nd}}(\mathrm{DM}-2 \mathrm{st})=2300$ млн лет указывают на палеопротерозойский (карельский) возраст континентальной коры. Островодужный комплекс ассоциирует с метаосадочными терригенными отложениями (кичерская свита) с линзами вулканитов (плагиориолитов) и карбонатных пород с низким (0.1348) Sm-Nd среднекоровым отношением и отрицательной коровой величиной $\varepsilon_{\text {Nd }}(\mathrm{T})$, равной -17.8. Эти метаморфизованные отложения имеют архейский $\mathrm{Nd}$ модельный возраст протолитов $\mathrm{T}_{\mathrm{Nd}}(\mathrm{DM}) 3430$ и $\mathrm{T}_{\mathrm{Nd}}(\mathrm{DM}-2 \mathrm{st}) 2829$ млн лет. Близкие параметры имеют плагиориолиты иньяптукской толщи $\left(\varepsilon_{\mathrm{Nd}}(830)=-10.61\right.$ и T ${ }_{\mathrm{Nd}}(\mathrm{DM}) 2794$ и $\mathrm{T}_{\mathrm{Nd}}(\mathrm{DM}-2 \mathrm{st}) 2388$ млн лет), расположенные по периферии Нюрундуканского ультрамафит-мафитового массива. Прорывающие их кичерские гнейсограниты имеют также отрицательную величину $\varepsilon_{\mathrm{Nd}}(\mathrm{T})=-12.3$, но более молодой Nd модельный возраст - 1760 и 1924 млн лет [Rytsk et al., $2001,2007]$. Нюрундуканский массив образует нижнюю часть офиолитового разреза, представленную породами нормальной щелочности - от перидотитов до расслоенных габброидов и дайкового комплекса [Tsygankov, 2005]. В результате более поздних коллизионных процессов и крупных сдвиговых перемещений с формированием структур присдвигового растяжения, затронувших всю структуру Байкало-Муйского пояса, офиолитовые комплексы Нюрундуканской островной дуги оказались разрозненными и перемещенными от мест своего первоначального формирования. Все эти фрагменты островной дуги относятся к супрасубдукционным офиолитовым образованиям [Dobretsov, 1983; Tsygankov, 2005].

Дунжугурская островная дуга расположена на юговостоке Восточного Саяна, в верховьях р. Оки [Sklyarov, Dobretsov, 1987; Dobretsov et al., 1989a; Gordienko et al., 2016; Sklyarov et al., 2016]. Геохимические характеристики дунжугурских надсубдукционных комплексов отвечают энсиматическому типу дуг. Характерен толеитовый и известково-щелочной тренды дифференциации. Вулканогенный комплекс представлен крайне низкотитанистыми и низкожелезистыми андезитами и андезибазальтами с повышенным содержанием $\mathrm{MgO}$ и $\mathrm{Cr}_{2} \mathrm{O}_{3}$. Среди них выделяются типичные бониниты и марианиты. В распределении РЗЭ отмечается характерная отрицательная аномалия по Тa, $\mathrm{Nb}$ и Ti. Во фронтальной части дуги формировались кислые вулканокластические породы. Детритовые цирконы в них имеют возраст от $1048 \pm 12$ млн лет до $844 \pm 8$ млн лет [Kuzmichev, Larionov, 2013]. Эта оценка указывает на возможно более древний, чем предполагалось ранее (U-Pb - 1010 \pm 10 млн лет, $\mathrm{Pb}-\mathrm{Pb}-1020 \pm 0.7$ млн лет), возраст магматизма Дунжугурской дуги [Khain et al., 2002]. $\mathrm{Sm}-\mathrm{Nd}$ изотопные исследования дунжугурского офиолитового комплекса показали слабоотрицательные и положительные величины $\varepsilon_{\mathrm{Nd}}(\mathrm{T})$ в узком интервале от -1.0 до +1.5, близком к хондритовому источнику CHUR, и позднепалеопротерозойский $\mathrm{Nd}$ модельный возраст $\mathrm{T}_{\mathrm{Nd}}(\mathrm{DM})=1.8-1.6$ млрд лет. Дунжугурские офиолиты имеют отчетливую надсубдукционную геохимическую специфику со всеми признаками их формирования в условиях спрединга [Sklyarov et al., 2016].

Дунжугурская, Нюрундуканская и Арзыбейская дуги могут рассматриваться в качестве наиболее древних дуг на неопротерозойской активной окраине [Gordienko, 2019a]. Возможно, они функционировали на окраинах древнего океана еще до распада Родинии, что в определенной степени сближает их с древнейшими дугами Западной Монголии и Таймыра [Kheraskova et al., 2010, 2014; Gordienko, Metelkin, 2016]. 


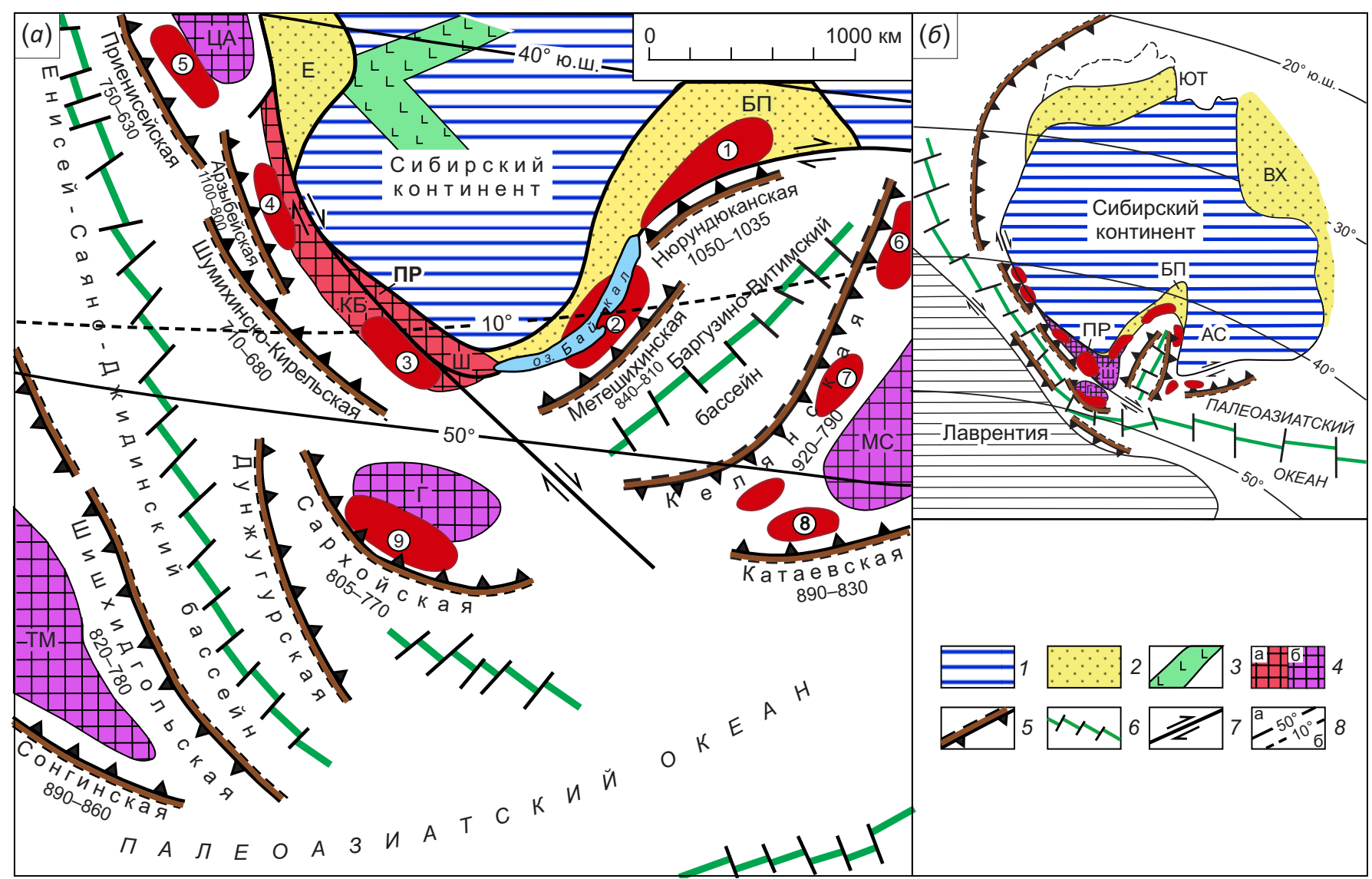

Рис. 6. Палеогеодинамическая реконструкция неопротерозойской активной окраины Сибирского континента и Палеоазиатского океана (по [Gordienko, 2019a]).

(a) - региональная реконструкция (по [Gordienko, 2006, 2008], с изменениями и дополнениями); (б) - глобальная реконструкция (по [Metelkin, 2012]). 1 - Сибирский континент; 2 - пассивные окраины континента (БП - Байкало-Патомская, Е - Енисейская, ЮТ - Южно-Таймырская, ВХ - Верхоянская); 3 - неопротерозойские авлакогены (рифты) на Сибирской платформе; 4 кратонные блоки (ЦА - Центрально-Ангарский, КБ - Канско-Бирюсинский, ПР - Протеросаянский, Ш - Шарыжалгайский) (а), микроконтиненты (ТМ - Тувино-Монгольский, Г - Гарганский, МС - Муйско-Становой) (б); 5 - островные дуги с указанием возраста, ориентировки зон субдукции (треугольники), положения аккреционного клина (штриховая линия) и окраинных бассейнов (белый цвет); 6 - предполагаемые зоны спрединга в окраинных бассейнах и Палеоазиатском океане; 7 - крупные сдвиги; 8 - палеошироты для рубежа 850 млн лет назад (а) и 750 млн лет назад (б) по палеомагнитным данным [Metelkin, 2012].

Ареалы и поля плюмового магматизма, показанные красным цветом (цифры в кружочках): 1 - Олокит-Довырен-Бодайбинский, 2 - Ольхон-Урбикан-Намаминский, 3 - Барбитай-Жидой-Белозиминский, 4 - Канско-Кингашский, 5 - ТатарскоИшимбинский, 6 - Каралон-Кедровско-Ирокиндинский, 7 - Амалат-Верхневитимский, 8 - Малхано-Яблоновый, 9 - СархойЮжногарганский. Масштаб дан для Сибирского кратона. Островные дуги, спрединговые зоны и микроконтиненты показаны вне масштаба.

Fig. 6. Paleogeodynamic reconstructions of the Neoproterozoic active margin of the Siberian continent and the Paleo-Asian Ocean (after [Gordienko, 2019a]).

(a) - regional reconstruction (modified after [Gordienko, 2006, 2008]); (б) - global reconstruction (after [Metelkin, 2012]). 1 - Siberian continent; 2 - passive continental margins (БП - Baikal-Patom, E - Yenisey, ЮT - South Taimyr, BX - Verkhoyansk); 3 - Neoproterozoic aulacogens (rifts) on the Siberian platform; 4 - cratonic blocks (ЦА - Central Angara, КБ - Kansk-Biryusa, ПР - Proterosayan, Ш Sharyzhalgay) (a), microcontinents (TM - Tuva-Mongolia, $\Gamma$ - Gargan, MC - Muya-Stanovoy) (б); 5 - island arcs and their ages, orientations of subduction zones (triangles), positions of accretionary wedge (dashed line) and marginal basins (white colour); 6- suggested spreading zones in the marginal basins and the Paleo-Asian Ocean; 7 - major strike-slip faults; 8 - paleolatitudes at 850 Ma (a) and 750 Ma (б) according to paleomagnetic data [Metelkin, 2012].

Areas and fields of plume magmatism (red colour, numbers in circles): 1 - Olokyt-Dovyren-Bodaibo, 2 - Olkhon-Urbikan-Namama, 3 Barbitay-Zhidoy-Belaya Zima, 4 - Kansk-Kingash, 5 - Tatar-Ishimba, 6 - Karalon-Kedr-Irokinda, 7 - Amalat-Upper Vitim, 8 - MalkhanYablonovy, 9 - Sarkhoy-South Gragan. The scale applies to the Siberian craton. It does not apply to the island arcs, spreading zones and microcontinents. 
Среди докембрийских дуг, связанных с неопротерозойской активной окраиной ПАО, реконструированы Метешихинская, Келянская, Катаевская и Сонгинская (Холбонурская) островные дуги (см. рис. 3; рис. 6).

Фрагменты Метешихинской островной дуги вскрываются южнее Нюрундуканской дуги. Они представлены метабазальтами и метатерригенно-карбонатными породами итанцинской свиты и рядом ультрабазитбазитовых массивов (Метешихинский, Острая сопка, Фурай, Водораздельный, Бурлаковский, Бурлинский, Урбиканский и другие более мелкие тела), которые располагаются в основном среди обширных полей палеозойских гранитоидов вдоль восточного побережья озера Байкал от устья р. Селенги до бассейна р. Урбикан и верховьев р. Баргузин на расстоянии свыше 350 км.

По вещественному составу они представлены двумя группами пород - базитовой, составляющей основной объем, и ультрабазитовой. Группа базитовых пород включает метабазальты, расслоенную серию, варьирующуюся по составу от оливиновых габбро до лейкократовых габбро и анортозитов. U-Pb возраст базальтов по цирконам составляет 839 11 млн лет. Величина $\varepsilon_{\mathrm{Nd}}(\mathrm{T})$ положительная (+5.3), что указывает на их ювенильный мантийный источник, близкий к DM. Nd Moдельный возраст протолитов $\mathrm{T}_{\mathrm{Nd}}(\mathrm{DM})=1149$ и $1211 \mathrm{млн}$ лет (поздний мезопротерозой). ${ }^{40} \mathrm{Ar} /{ }^{39} \mathrm{Ar}$ возраст по роговой обманке из габброидов Метешихинского массива составляет 809.2 55.9 млн лет и массива Острая сопка 844 млн лет [Bulgatov, 2015; Orsoev et al., 2015]. Величина $\varepsilon_{\mathrm{Nd}}(\mathrm{T})$ положительная $(+0.63)$, близкая к хондритовому источнику CHUR. Группа ультрабазитовых пород сложена верлитами, плагиоверлитами и оливиновыми клинопироксенитами. Содержание и характер распределения петрогенных элементов в породах Метешихинского массива отвечают тренду фракционной кристаллизации базальтовой магмы E-MOR-типа. Присутствие на спайдер-диаграммах интрузивных пород Sr-максимума отражает, по-видимому, присутствие субдукционной компоненты. Близкие $\mathrm{Nd}$ и $\mathrm{Sr}$ изотопные данные $\left({ }^{143} \mathrm{Nd} /{ }^{144} \mathrm{Nd}-0.5128-0.5129\right.$ и $0.5123-0.5125$; ${ }^{87} \mathrm{Sr} /{ }^{86} \mathrm{Sr}-0.7052-0.7063$ и 0.7039-0.7041) габброидных массивов и базальтов свидетельствуют о синхронности проявления неопротерозойского базальтового и интрузивного магматизма в пределах единого вулканоплутонического комплекса островодужного типа. Согласно проведенным палеогеодинамическим реконструкциям, Метешихинская островная дуга была связана с формированием Баргузино-Витимского океанического бассейна и образованием зоны субдукции под Сибирский континент [Orsoev et al., 2012, 2015; Gordienko, 2006, 2019a].

Келянская островная дуга в виде покровно-надвиговых структур и ареалов неопротерозойских СФК прослеживается от бассейна нижнего течения р. Муя (Средневитимская горная страна) через Витимское плоскогорье до верховьев рек Турка и Кыджимит Западного Забайкалья на расстояние свыше 500 км (см. рис. 3; рис. 6). Состав островодужного комплекса изменчивый.
Он включает туфы и лавы риолитов, плагиориолитов, андезибазальтов, базальтов и бонинитов известковощелочной серии с возрастом 830-790 млн лет. Фрагменты полного разреза надсубдукционных офиолитов выявлены на Усть-Келянском участке, а также в ЮжноМуйском хребте [Konnikov et al., 1999]. К западу от этих участков широко распространены гранитоиды муйского и кичерского габбро-тоналит-плагиогранит-гранитных комплексов, которые являются комагматами устькелянской толщи базальт-андезибазальт-риолитового состава с участием бонинитов [Tsygankov, 2005]. По изотопному составу $\mathrm{Nd}$ в риолитах усть-келянской толщи величина $\varepsilon_{\mathrm{Nd}}(790)$ положительная (4.4), что указывает на их ювенильный короткоживущий мантийный источник, близкий к DM. Nd модельный возраст протолитов $\mathrm{T}_{\mathrm{Nd}}(\mathrm{DM})=1232$ и 1134 млн лет (поздний мезопротерозой).

Далее к юго-западу в составе островодужных вулканогенных пород усть-келянской свиты выделяются риолиты горбылокской толщи с возрастом 825 млн лет и одновозрастные комагматы муйских гранитоидов, широко распространенных в междуречье рек Уакит, Ципа, Бамбуйка [Rytsk et al., 2011; Doronina et al., 2013]. Их величины $\varepsilon_{\mathrm{Nd}}(\mathrm{T})$ отрицательные $(-11.1$ и -8.3) соответственно, что указывает на долгоживущие коровые или смешанные источники. Nd модельный возраст протолитов более древний, палеопротерозойский - $\mathrm{T}_{\mathrm{Nd}}(\mathrm{DM})$ 2388-2274 и 1950-2055 млн лет.

В Икат-Багдаринской зоне аналогом усть-келянской толщи вулканитов является сивоконская свита с U-Pb возрастом 839.8ะ7.9 млн лет [Doronina et al., 2009а], сложенная базальт-андезит-риолитовой известковощелочной серией. Вулканогенные образования прорываются габброидами Шаманского хребта с U-Pb возрастом 778 млн лет [Rytsk et al., 2011]. В этом же районе закартирована ципиканская толща с возрастом ортосланцев по цирконам 810.1ะ8.4 млн лет и силлов мета-

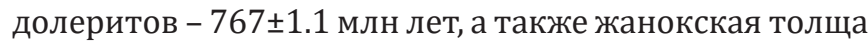
риолитов с U-Pb возрастом 750 млн лет [Doronina et al., 2009b]. В Котерской зоне Баргузино-Витимского прогиба выделена одноименная котерская серия, сложенная мощными толщами уколкитской (2500-3000 м), няндонинской (1500-2000 м) и баргузинской (20003000 м) свит. Серия сложена метаморфизованными в разной степени терригенно-карбонатными отложениями с прослоями и горизонтами вулканогенных пород, являющимися фрагментами задуговых бассейнов Келянской островной дуги.

В бассейне р. Турка и ее правого притока р. Ямбуй распространены риолиты и их туфы с U-Pb возрастом

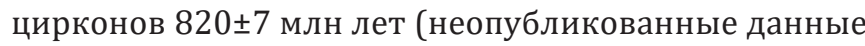
автора). Восточнее обнаружены послойные тела метабазальтов, метаандезибазальтов и метагаббро, метаморфизованных до амфиболитов и ортосланцев с линзообразными телами и пластинами серпентинитов и пикритов (асынская свита). По содержанию РЗЭ данные породы аналогичны бонинитам дуги Тонга. U-Pb изотопный возраст цирконов из толеитовых базальтов 
составляет 953 \pm 21 млн лет [Doronina et al., 2013]. Величина $\varepsilon_{\mathrm{Nd}}(\mathrm{T})$ положительная (+0.24), близкая к хондритовому источнику CHUR. Nd модельные возрасты протолитов мезопротерозойские - $\mathrm{T}_{\mathrm{Nd}}(\mathrm{DM})=1672$ и $1592 \mathrm{млн}$ лет. В северной части Витимского плоскогорья в бассейне р. Усой в составе островодужного комплекса, наряду с андезибазальтами, выявлены риолиты и их ту-

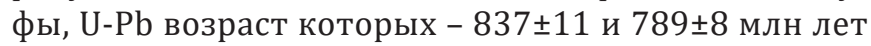
[Gordienko et al., 2009; Ruzhentsev et al., 2012]. Все эти надсубдукционные вулканические породы относятся к Келянской островной дуге энсиматического типа, которая образовалась в пределах юго-восточной части (в современных координатах) неопротерозойского Баргузино-Витимского океанического бассейна [Gordienko, 2019a].

К числу энсиалических дуг неопротерозоя относится Катаевская дуга [Gordienko, 2006; Gordienko, Metelkin, 2016]. До недавнего времени возраст магматизма, связанного с этой дугой, предполагался вендско-кембрийским. В результате U-Pb исследований цирконов (SHRIMP-II, по 8 точкам) из андезибазальтов стратотипического разреза катаевской свиты по р. Унго в Центральном Забайкалье получены возрасты от 832 12 до

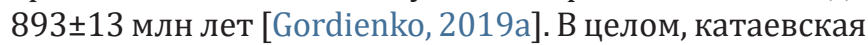
ассоциация представлена метабазальтами и метаандезибазальтами с небольшими прослоями хлорит-эпидот-серицитовых сланцев, прорванных дайками и небольшими телами габбро, габбро-долеритов и гранитов. По геохимическому составу базальты и андезибазальты относятся к калинатровой высокоглиноземистой серии. Содержание наименее подвижных высокозарядных и редкоземельных элементов более стабильное (г/т): $\mathrm{Zr}=170-240, \mathrm{Nb}=8-12, \mathrm{La}=25-41, \mathrm{Ce}=50-79$, $\mathrm{Yb}=2.1-2.8, \mathrm{Y}=21-25$. По этим параметрам катаевские вулканиты соответствуют современному магматизму развитых островных дуг [Avdeiko et al., 2001]. В андезибазальтах величина $\varepsilon_{\mathrm{Nd}}(\mathrm{T})$ положительная (+9.29), что указывает на ювенильный мантийный источник, близкий к обогащенной DM. Протолиты имеют неопротерозойский возраст $-\mathrm{T}_{\mathrm{Nd}}(\mathrm{DM})=762$ и 754 млн лет. Островодужные граниты оборского комплекса также характеризуются положительной величиной $\varepsilon_{\mathrm{Nd}}(\mathrm{T})=+0.99$ ювенильных источников, близких к хондритовому составу CHUR. Nd модельные возрасты гранитных протолитов являются неопротерозойскими - $\mathrm{T}_{\mathrm{Nd}}(\mathrm{DM})=910$ и 753 млн лет.

На территории Западной Монголии фрагменты неопротерозойских островодужных комплексов выявлены в Сонгинском и Дзабханском блоках. Сонгинский блок включает Холбонурскую островную дугу, зона субдукции которой, по-видимому, была направлена под Тувино-Монгольский микроконтинент (Сангиленский блок) (рис. 6). Здесь изучено несколько тектонических пластин общей мощностью около 2 км. Пластины сложены метабазальтами OIB, E-MORB и островодужными вулканитами базальт-андезит-риолитового состава. Их U-Pb возраст составляет от 860 до 890 млн лет, величина $\varepsilon_{\mathrm{Nd}}(\mathrm{T})$ положительная $(+6.5$ и +7.0$)$, близкая к обогащенной DM. T ${ }_{\mathrm{Nd}}(\mathrm{DM})=1037-1038$ млн лет указывает на мезонеопротерозойский возраст протолитов континентальной коры. Ассоциирующие с вулканитами гранитоиды гашунурского и дзабханского комплексов с возрастом 859 и 856 млн лет также имеют положительные величины $\varepsilon_{\mathrm{Nd}}(\mathrm{T})$ от +1.6 до +3.1, но более древние (мезопротерозойские) $\mathrm{Nd}$ модельные возрасты протолитов $\mathrm{T}_{\mathrm{Nd}}(\mathrm{DM})$ и $\mathrm{T}_{\mathrm{Nd}}$ (DM-2st) от 1400 до 1900 млн лет [Yarmolyuk et al., 2015, 2017; Kozakov et al., 2013].

Раннекаледонский этап связан с историей заложения, развития и закрытия Палеоазиатского океана. Эдиакарий-раннепалеозойские офиолитовые и островодужные ассоциации по составу и структурному положению в основном отвечают геодинамическим обстановкам западно-тихоокеанского типа - окраинных морей, островных дуг, активных и пассивных континентальных окраин, спрединговых зон и зон трансформных разломов на границе континент - океан [Gordienko, 2006, 2019a; Zorin et al., 2009] (рис. 7).

Отличительной особенностью раннекаледонского этапа является присутствие бонинитовых вулканических серий и, в целом, толеитовая специфика магматизма, связанная с энсиматическими дугами и океаническими островами (гайотами) с плюмовым магматизмом, широко представленными на окраинах ПАО [Dobretsov et al., 2004; Gordienko, Metelkin, 2016; Sklyarov et al., 2016].

На территории Монголо-Забайкальского региона выделяются довольно хорошо изученные фрагменты Ангино-Таланчанской, Джидинской, Удино-Витимской, Озерной, Баян-Хонгорской островодужных систем эдиакария - нижнего палеозоя, с формированием которых связан также разнообразный внутриплитный магматизм, рассмотренный ниже в специальном разделе.

Ангино-Таланчанская островодужная система была выделена по берегам озера Байкал: в Приольхонье и Восточном Прибайкалье, включая Баргузинский хребет [Gordienko, 2006; Makrygina et al., 2007]. Существование дуги подтверждается широким развитием нижнепалеозойских магматитов от базальтового до андезитового состава. Эти породы характеризуются высокими концентрациями $\mathrm{Sr}, \mathrm{K}, \mathrm{Th}, \mathrm{Ti}, \mathrm{P}$ и низким содержанием $\mathrm{Nb}, \mathrm{Ce}, \mathrm{Zr}$ и $\mathrm{Cr}$, что свойственно зрелым островным дугам. Исследования вещественного состава пород Таланчанского сектора островодужной ассоциации в Восточном Прибайкалье [Makrygina et al., 2007] показали, что амфиболовые, амфибол-биотитовые и биотит-амфиболовые гнейсы и сланцы таланчанской свиты реставрируются как вулканиты островодужного типа, аналогичные ангинским метабазальтам, метаандезитам и дацитам. По соотношению редких элементов они не отличаются от метаграувакк ангинской толщи. В Ангинском секторе дуги Приольхонья ранее были выявлены метаморфизованные породы - габбро, диориты, гранодиориты с островодужными параметрами, близкими к островодужным метавулканитам, что свидетельствует об их комагматичности [Makrygina et al., 2007]. Подобные габброиды и гранитоиды обнаружены в Бирамьинской и 
Светлинской зонах северо-восточной части Баргузинского хребта, где они имеют кембро-ордовикский возраст 550-468 млн лет, положительные величины $\varepsilon_{\mathrm{Nd}}(\mathrm{T})$ от +5.7 до +5.4 с ювенильными источниками, близкими к $\mathrm{DM}$, и неопротерозойские $\mathrm{Nd}$ модельные возрасты протолитов $\mathrm{T}_{\mathrm{Nd}}(\mathrm{DM})=780$ и 980 и $\mathrm{T}_{\mathrm{Nd}}(\mathrm{DM}-2 \mathrm{st})=806$ и $760 \mathrm{Mлн}$ лет соответственно [Rytsk et al., 2007].

В последнее время в пределах Ольхонского террейна получены новые доказательства присутствия в составе цаганзабинской базальт-андезит-риолитовой толщи и комагматичных ей надсубдукционных габброидов Бирхинского массива фрагментов зрелой островной дуги верхнекембрийского возраста с участием плюмового магматизма (502.2 23.4 млн лет первой фа-

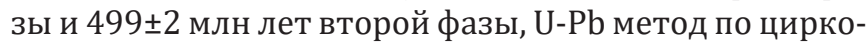
ну) [Lavrenchuk et al., 2017]. Вулканиты и габброиды обнаруживают близкие слабофракционированные спектры распределения P3Э (La/Y, 2.6-3.4). На диаграмме в спектрах габброидов и метабазальтов отмечены хорошо выраженные отрицательные аномалии по $\mathrm{Nb}, \mathrm{Ta}, \mathrm{Ti}$ и положительные аномалии по Sr. Габброиды Бирхинского массива и вулканиты цаганзабинского комплекса обнаруживают близкие положительные величины $\varepsilon_{\mathrm{Nd}}(\mathrm{T})=+2.9 \ldots+4.0$ ювенильных источников и неопротерозойские значения $\mathrm{Nd}$ модельного возраста $\mathrm{T}_{\mathrm{Nd}}(\mathrm{DM})=$ =819-930 млн лет [Gladkochub et al., 2014].

Другим своеобразным представителем Саяно-Байкальской ветви эдиакарий-раннепалеозойской активной окраины Палеоазиатского океана является Удино-Витимская островодужная система энсиалического типа. Ее фрагменты прослеживаются от бассейна р. Курба, вдоль долины р. Уда до верховьев р. Витим на расстояние более 300 км. Образование дуги в начале эдиакария связано с формированием Забайкальского спредингового бассейна ПАО, который возник на месте интенсивного проявления островодужного и плюмового магматизма неопротерозойского этапа в пределах Баргузино-Витимского океанического бассейна [Gordienko et al., 2010; Ruzhentsev et al., 2012]. Основу островодужного комплекса составляют мощные шлейфы вулканокластитов и лав среднего, кислого и смешанного состава с рядом небольших рифовых карбонатных построек с археоциатами и трилобитами нижнего кембрия. По петрохимическим характеристикам вулканиты относятся к высокоглиноземистым, низкотитанистым породам. Они подразделяются на нормальную, субщелочную, умеренно высококалиевую и шошонитлатитовую серии. Установлена характерная поперечная вещественная зональность вулканитов [Lantseva, 2014]. От фронта в тыл (с юго-востока на северо-запад) растет содержание $\mathrm{K}_{2} \mathrm{O}$, возрастают концентрации некогерентных и редких элементов, таких как $\mathrm{Rb}, \mathrm{Sr}, \mathrm{U}$, $\mathrm{Th}, \mathrm{La}, \mathrm{Ce}, \mathrm{Nb}, \mathrm{Zr}, \mathrm{Hf}$, а также величины отношений Rb/Sr, $\mathrm{La} / \mathrm{Yb}, \mathrm{Sr} / \mathrm{Ce}, \mathrm{Th} / \mathrm{U}, \mathrm{Zr} / \mathrm{Y}, \mathrm{La} / \mathrm{Nb}, \mathrm{Fe}_{2} \mathrm{O}_{3} /\left(\mathrm{FeO}+\mathrm{Fe}_{2} \mathrm{O}_{3}\right)$. Такая геохимическая специфика сближает данную базальтандезит-дацит-риолитовую ассоциацию со зрелыми островодужными системами наподобие Курило-Камчатской [Avdeiko et al., 2001].
По данным U-Pb изотопного датирования вулканитов получены ранне- и среднекембрийские возрасты $529 \pm 3$ млн лет и 516 5 млн лет. По изотопным данным кислые вулканиты (риолиты) олдындинской свиты имеют отрицательные величины $\varepsilon_{\mathrm{Nd}}(\mathrm{T})$ от -8.7 до - 1.3 , указывающие на энсиалические источники коры с палеопротерозойским $\mathrm{Nd}$ модельным возрастом протолитов $\mathrm{T}_{\mathrm{Nd}}(\mathrm{DM})=2000-1400$ млн лет. Близкие результаты изотопных данных имеют метатерригенные осадки названной свиты (Приложение 1) [Ruzhentsev et al., 2012]. Заключительному этапу формирования островодужной ассоциации отвечают интрузии габбро, диоритов, тоналитов и плагиогранитов [Gordienko, 2006; Gordienko et al., 2010; Goneger, 2018]. Проведенные палеомагнитные исследования описанного вулканического комплекса доказывают, что структуры дуги эволюционировали в составе единой активной окраины с островными дугами Алтае-Саянского орогена. Важной особенностью, вытекающей, в том числе, из анализа палеомагнитных данных, является трансформный характер границ континентальной и океанической литосферных плит на рубеже кембрия - ордовика [Metelkin, 2013].

Структуры Джидинской островодужной системы в составе собственно островной дуги, гайотов и задуговых бассейнов занимают огромную площадь (около $500 \mathrm{\kappa м}^{2}$ ) на территории Юго-Западного Забайкалья и Северной Монголии. Она продолжает цепь каледонских островных дуг юго-восточной окраины Сибирского континента. В ее пределах выявлен полный разрез эдиакарий-раннекембрийской офиолитовой ассоциации (U-Pb изотопный возраст габбро-пироксенитов и плагиогранитов 562-554 млн лет), разнообразные островодужные комплексы, коллизионные и постколлизионные гранитоиды. Островодужные комплексы представлены вулканическими и туфогенно-осадочными породами энсиматической островной дуги, крупных симаунтов (гайотов), преддугового и задугового бассейнов, а также габбро-диорит-тоналит-плагиогранитной ассоциацией пород повышенной основности, завершающей формирование Джидинской островодужной системы на окраине ПАО [Al'mukhamedov et al., 1996; Gordienko et al., 2007, 2015, 2018a]. Начальный этап развития Джидинской энсиматической островной дуги фиксируется эдиакарий-раннекембрийскими породными ассоциациями гайотов, базитов-гипербазитов (U-Pb, 560 5 млн лет) [Elbaev et al., 2018], расслоенного кумулятивного и дайкового комплексов, примитивных толеитов с участием бонинитов (U-Pb, 542 млн лет) [Tomurhuu et al., 2007] и более поздних андезибазальтов известково-щелочной серии. Надсубдукционные офиолиты островной дуги, включая базальты ОIB, имеют высокие положительные величины $\varepsilon_{\mathrm{Nd}}(\mathrm{T})=+9.2$, $+6.4,+3.5$ ювенильной коры, близкой по составу к обогащенной DM (Приложение 1; см. рис. 4).

Следующий этап развития дуги связан с появлением излияний среднего и кислого состава (риолит-андезитовая толща), формировавших морфологически выраженные вулканические постройки, окруженные 

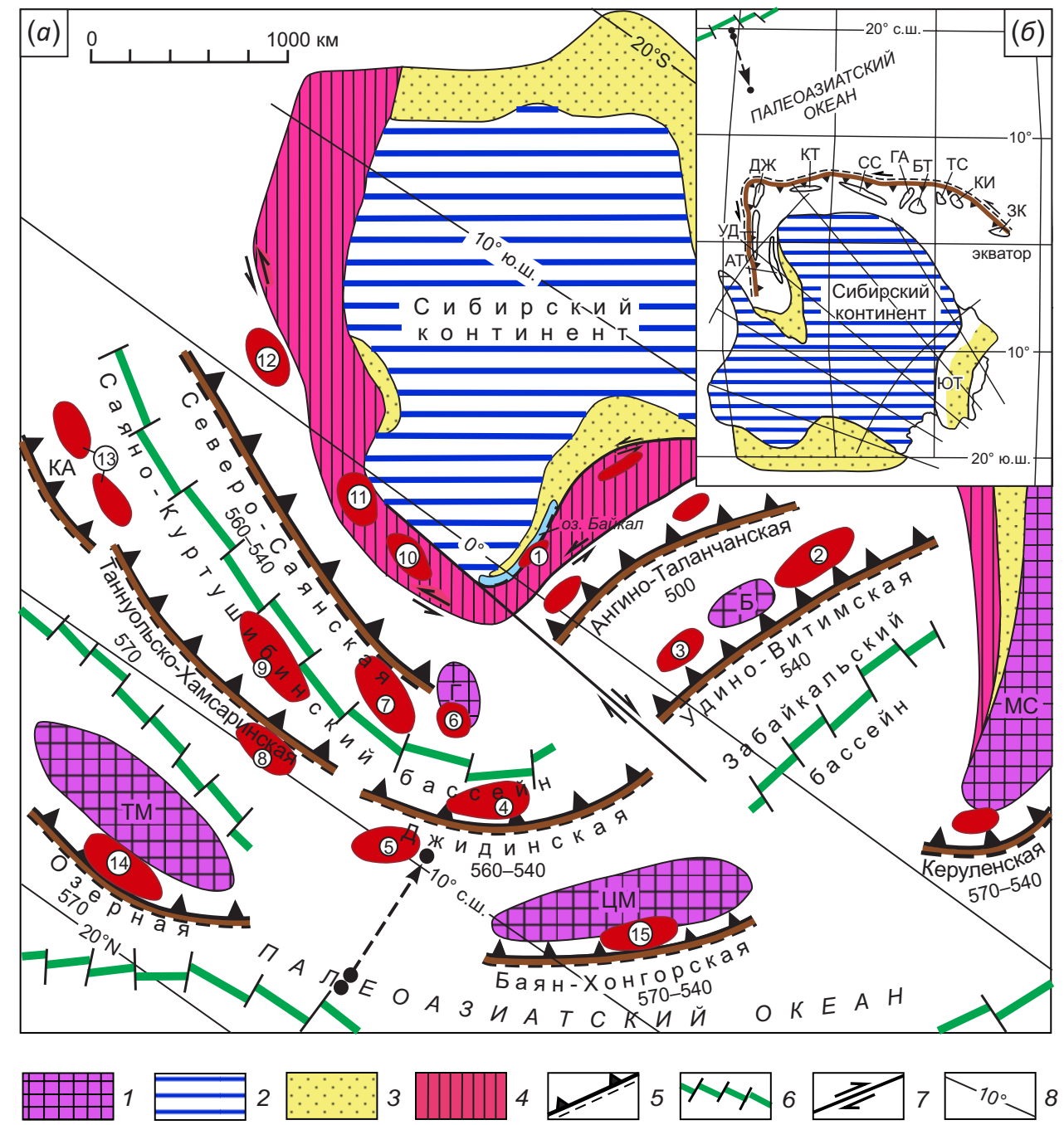

Рис. 7. Палеогеодинамическая реконструкция эдиакарий-раннепалеозойской активной окраины Сибирского континента и Палеоазиатского океана (по [Gordienko, 2019a]).

(a) - региональная реконструкция (по [Gordienko, 2006, 2008], с изменениями и дополнениями); (б) - глобальная реконструкция (по [Metelkin, 2013]). 1 - выступы Сибирского кратона и кратонные террейны (ТМ - Тувино-Монгольский, Г - Гарганский, Б - Байкальский, ЦМ - Центрально-Монгольский, МС - Муйско-Становой); 2 - платформенный комплекс Сибирского континента; 3 - осадочные бассейны пассивной окраины континента; 4 - неопротерозойский аккреционный ороген; 5 - островные дуги с указанием ориентировки зоны субдукции (треугольники) и положения аккреционного клина (штриховая линия); 6 предполагаемые зоны спрединга ПАО, включая задуговые бассейны; 7 - крупные сдвиги; 8 - палеошироты для венда - раннего кембрия (по [Metelkin, 2012]). На врезке показаны островные дуги Забайкалья и Алтае-Саянской области: ДЖ - Джидинская, УД - Удино-Витимская, АТ - Ангино-Таланчанская, СС - Северо-Саянская и другие (по [Metelkin, 2012]). Пунктирной линией показано реконструированное движение океанической плиты с гайотами от спрединговой зоны ПАО к зоне субдукции Джидинской дуги (по [Gordienko, Mikhal'tsov, 2001]). Ареалы плюмового магматизма, показанные красным цветом (цифры в кружочках): 1 -Тажеранский, 2 - Витимский, 3 - Ульзутуйский, 4 - Джидотский, 5 - Ургольский, 6 - Южногарганский, 7 - Ботогольский, 8 - Мажалыкский, 9 - Куртушибинский, 10 - Гутарский, 11 - Черносопкинский, 12 - Порожинский, 13 - Эдельвейс и др. Масштаб дан для Сибирского кратона. Островные дуги, спрединговые зоны и микроконтиненты показаны вне масштаба.

Fig.7. Paleogeodynamic reconstructions of the Ediacaran - Early Paleozoic active margin of the Siberian continent and the Paleo-Asian Ocean (after [Gordienko, 2019a]).

(a) - regional reconstruction (modified after [Gordienko, 2006, 2008]); (б) - global reconstruction (after [Metelkin, 2013]). 1 - uplifts of the Siberian craton and cratonic terranes (TM - Tuva-Mongolia, $\Gamma$ - Gargan, Б - Baikal, ЦM - Central Mongolian, MC - Muya-Stanovoy); 2 - platform complex of the Siberian continent; 3 - sedimentary basins of the passive continental margin; 4 - Neoproterozoic accretionary orogen; 5 - island arcs, orientations of subduction zones (triangles), and the accretionary wedge (dashed line); 6 - suggested spreading zones of the Paleo-Asian Ocean, including back-arc basins; 7 - major strike-slip faults; 8 - paleo-latitudes for the Vendian Early Cambrian (after [Metelkin, 2012]). The inset shows the island arcs of Transbaikalia and the Altay-Sayan region: ДЖ - Dzhida, УД Uda-Vitim, AT - Anga-Talanchan, CC - North Sayan etc. (after [Metelkin, 2012]). Dashed line - reconstructed movement of the oceanic plate with guyots from the spreading zone of the Paleo-Asian Ocean towards the subduction zone of the Dzhida arc (after [Gordienko, Mikhal'tsov, 2001]). Areas of plume magmatism (red colour, numbers in circles): 1 - Tazheran, 2 - Vitim, 3 - Ulzutui, 4 - Dzhidot, 5 Urgol, 6 - South Gargan, 7 - Botogol, 8 - Mazhalyk, 9 - Kurtushibin, 10 - Gutar, 11 - Chernaya Sopka, 12 - Porozhinsky, 13 - Edelweiss etc. The scale applies to the Siberian craton. It does not apply to the island arcs, spreading zones and microcontinents. 
рифовыми известняками, содержащими раннекембрийские археоциаты. Переход островной дуги от юной к зрелой стадии развития связывается с началом массовых излияний и эксплозий вулканитов среднего состава. В этот период сформировалась мощная толща преимущественно псаммитовых тефротурбидитов андезибазальтового состава. Почти одновременно (средний кембрий) образовались многочисленные интрузивные тела габбро, диоритов, кварцевых диоритов и плагиогранитов (джидинский комплекс) с возрастом 506-504 млн лет (U-Pb метод) [Gordienko et al., 2006]. Совокупность геологических, петро- и геохимических данных позволяет отнести эти габброиды и гранитоиды к надсубдукционному I-типу, формировавшемуся в условиях островных дуг. Данные габброиды и гранитоиды офиолитовых и островодужных ассоциаций имели U-Pb возраст по цирконам от 504 до 560 млн лет. $\mathrm{Nd}$ модельный возраст их протолитов $\mathrm{T}_{\mathrm{Nd}}(\mathrm{DM}-2 \mathrm{st})$ 740, 682, 675, 586 млн лет указывает на поздненеопротерозойские и эдиакарские $\mathrm{Nd}$ модельные возрасты протолитов континентальной коры, связанных с мантийными источниками расплавов DM, что подтверждается положительными величинами $\varepsilon_{\mathrm{Nd}}(\mathrm{T})$ от +3.49 до +8.50 . По своим изотопным характеристикам породы джидинского интрузивного комплекса вполне сопоставимы с гранитоидами каледонской изотопной провинции Центральной Азии [Kovalenko et al., 2006].

Терригенные породы зунмуринской и джидинской свит имеют значения $\mathrm{T}_{\mathrm{Nd}}(\mathrm{DM})=1.8-1.6$ млрд лет [Makrygina et al., 2010]. По геохимическим данным, терригенные породы джидинской флишоидной свиты задугового бассейна имеют преимущественно основной и средний состав, низкие концентрации щелочных и щелочно-земельных элементов (Rb, Ba, K) и LREE и высокие содержания $\mathrm{Ni}, \mathrm{Cr}$. Наряду с особенностями изотопного состава $\mathrm{Nd}$, это свидетельствует о смешанных источниках сноса терригенного материала, ювенильном и коровом источнике пород основного и кислого состава. Осадочно-вулканогенные образования хасуртинской свиты Джидинской зоны характеризуются положительными значениями $\varepsilon_{\mathrm{Nd}}(0.55)=+3.1 \ldots+3.7$ (Приложение 1 ), повышенными отношениями ${ }^{147} \mathrm{Sm}^{144} \mathrm{Nd}=0.1457-0.1628$, близкими к островодужным габброидам [Gordienko et al., 2006; Makrygina et al., 2010], и находятся в поле эволюции изотопного состава $\mathrm{Nd}$ островодужных базальтов Джидинской зоны. Метаграувакки Хамардабанской зоны обладают палеопротерозойскими значениями $\mathrm{Nd}$ модельных возрастов $\mathrm{T}_{\mathrm{Nd}}(\mathrm{DM})$ в интервале 2.0-1.8 млрд лет [Reznitsky et al., 2008] и могли выступать в качестве одного из источников коллизионных гранитоидов.

Джидинская островодужная система является довольно хорошо изученной и по своим структурно-геологическим, петролого-геохимическим, геохронологическим и $\mathrm{Sm}-\mathrm{Nd}$ изотопным параметрам может быть сопоставлена с другими раннекаледонскими островными дугами Юго-Западной Монголии и Алтае-Саянской области, сыгравшими большую роль в формировании складчатой системы каледонид: Озерной, Баян-Хонгорской, Таннуольско-Хамсаринской.

Так, в пределах Озерной зоны каледонид Западной Монголии выявлена и хорошо изучена одноименная островодужная система, образованная в эдиакарийкембрийское время (570-490 млн лет) в обстановке внутриокеанических островных дуг и океанических плато. На островодужной и аккреционной стадиях развития Озерной зоны (540-490 млн лет) происходило становление гранитоидов натровой серии высоко- и низкоглиноземистого типа. Геохимические и $\mathrm{Nd}$-изотопные данные свидетельствуют о том, что источником исходных известково-щелочных расплавов базальтов, андезитов и дацитов островодужных комплексов являлась главным образом деплетированная мантия. Установлено, что на начальной стадии развития островодужной системы в петрогенезисе океанических плато (гайотов), базальтов и габброидов участвовал обогащенный плюмовый источник [Yarmolyuk et al., 2011; Kovach et al., 2011; Rudnev, 2013].

Баян-Хонгорская островодужная система выделена в центральной части Монголии и изучалась многими исследователями [Kovalenko et al., 2005; Kozakov et al., 2008; Terent'eva et al., 2010; и др.]. В пределах островодужной системы были выделены офиолитовые комплексы и базальты океанических плато (гайотов) с возрастом 665 15 млн лет [Кovach et al., 2005]. Было установлено, что вначале островодужная система, так же как и Джидинская и Озерная, развивалась в режиме крупного гайота и только начиная с возраста 570 млн лет она стала развиваться в режиме островной дуги. К островодужному комплексу были отнесены базальты N-MORB типа, андезибазальты, андезиты, дациты и их туфы, а также расслоенное габбро с жильными плагиогранитами с возрастом $577 \pm 2$ млн лет. По геохимическому составу выделенные габброиды, в частности изученный Ханулинский габброидный массив, отнесены к субдукционным образованиям [Terent'eva et al., 2010].

Таннуольско-Хамсаринская островодужная система была заложена в эдиакарии (570 млн лет назад) в связи с формированием Саяно-Куртушибинского океанического бассейна и прекратила свое развитие к началу кембрия, хотя процесс субдукции развивался до конца кембрия, когда островодужная система превратилась в активную континентальную окраину, на которой образовались магматические породы как с островодужными, так и с внутриплитными геохимическими параметрами. Островодужные магматические породы представлены базальтами и риолитами с отрицательными аномалиями по $\mathrm{Nb}, \mathrm{Ta}$, Ті и положительными величинами $\varepsilon_{\mathrm{Nd}}(\mathrm{T})=+8.4 \ldots+6.8$ ювенильной коры, габброидами и гранитоидами (кварцевыми диоритами) с островодужными геохимическими параметрами, геологическим возрастом 540-520 млн лет и также с положительными величинами $\varepsilon_{\mathrm{Nd}}(\mathrm{T})=+7.8 \ldots+7.0$, близкими к обогащенной DM [Mongush et al., 2011].

Продолжением к северо-западу Таннуольско-Хамсаринской дуги является Кузнецко-Алатаусская и 
Горно-Алтайская островодужные системы, в задуговой области которых произошло формирование океанических плато и островов (симаунтов) [Safonova et al., 2011] и образование ареалов щелочного магматизма и карбонатитов (Эдельвейс и др.) [Vrublevsky et al., 2009].

На раннегерцинском этапе (девон - ранний карбон) в структурах Монголо-Забайкальского региона сформировалась Хангай-Хэнтэй-Даурская система окраинных спрединговых морей и окружающих их островных дуг Монголо-Охотского океанического бассейна (рис. 8), а также раннекаменноугольная Южно-Монгольская островодужная система северной окраины Палеотетиса [Yarmolyuk, Kovalenko,1982], которая, по-видимому, была удалена от Сибирского континента на значительное расстояние [Gordienko, 2006, 2008, 2019а] (см. рис. 3).

Хангай-Хэнтэйская система глубоководных окраинных морей была окружена островными дугами с зонами субдукции различной протяженности (СевероХангайская, Северо-Хэнтэйская (Береинская), СевероАгинская, Уртуйская, Адацагская, Норовлин-Ононская, Ольдойская и др.), в которых в течение девона и раннего карбона проявился островодужный и плюмовый магматизм с формированием океанических островов, плато (симаунтов и гайотов) и задуговых морских бассейнов с бореальной фауной [Gordienko, 1987, 2019a]. Все эти островные дуги еще недостаточно изучены. Однако выявленные субдукционно-аккреционные процессы на окраине крупного Монголо-Охотского океанического бассейна сыграли важную роль в геологической эволюции Центрально-Азиатского и Монголо-Охотского складчатых поясов [Ruppen et al., 2014; Gordienko et al., 2018b, 2019b; Yarmolyuk et al., 2018; Gordienko, 2019a].

\section{2. Аккреционно-коллизионные процессы} в формировании континентальной коры региона

Современное мозаично-покровно-блоковое строение Монголо-Забайкальского региона, занимающего значительную часть трансрегионального ЦАСП, указывает на большую роль в его формировании аккреционно-коллизионных и сдвиговых процессов. Эти тектонические движения активно участвовали в образовании континентальной коры региона как в период становления собственно островодужных структур с образованием аккреционных призм и вулканических построек, так и при образовании задуговых окраинных бассейнов с вулканогенно-осадочным накоплением, а также в переработке более древних блоков метаморфических пород, попадающих в зону субдукции, в том числе и надсубдукционных офиолитов.

Процессы коллизии часто связаны постепенными переходами с процессами субдукции. Согласно исследованиям [Dobretsov, 2011b], в развитии складчатых поясов можно выделить три случая такой коллизии: 1) коллизия при продолжающейся субдукции; 2) коллизия после субдукции и 3) коллизия, оторванная в пространстве и во времени от субдукции. В качестве примеров для первого случая приводится перескок зон субдукции при закупорке ее океаническими островами или плато (гайотами), например Катунским и Джидотским гайотами в Алтае-Саянской области. Второй случай произошел при движении Индийской плиты в сторону Тибетского плато (континентальная коллизия), где плита разрушила существовавшую зону субдукции и столкнулась с Азиатской плитой. Третий случай также связан с Индийской плитой, которая при дальнейшем движении к северу вызвала торошение тектонических блоков Азии, вплоть до Байкальской рифтовой зоны. Нами при анализе связи субдукционных и аккреционно-коллизионных процессов в Монголо-Забайкальском регионе хорошо диагностируется первый и второй случаи в несколько ином варианте развития.

В архейский этап в Присаянском выступе Сибирского кратона коллизионными комплексами являются ультрамафит-мафитовые породы Сарамтинского массива Шарыжалгайского блока и гранитоиды китойского комплекса S- и I-типа с U-Pb возрастом $2532 \pm 12$ млн лет. Они имеют отрицательную величину $\varepsilon_{\mathrm{Nd}}(\mathrm{T})=-3.2$ и архейский $\mathrm{Nd}$ модельный возраст протолита $\mathrm{T}_{\mathrm{Nd}}(\mathrm{DM})=$ =3168 млн лет. Подобные гранитоиды зафиксированы также в Гарганской глыбе с возрастом 2730 млн лет, в пределах Алдано-Станового блока, в Байдарикском блоке Монголии с $\mathrm{Nd}$ модельным возрастом, равным 3.3 и 2.9 млрд лет [Gladkochub et al., 2001, 2005; Mazukabzov et al., 2006; Kozakov et al., 2007].

В карельский этап коллизионные процессы продолжались в пределах Байкало-Патомской окраины Сибирского кратона. Здесь выделяются мощные дислоцированные и высокометаморфизованные толщи патомского комплекса, насыщенные разновозрастными коллизионными гранитоидами с возрастом 20201890 до 1880-1838 млн лет [Rytsk et al., 2011]. В коллизионно-аккреционный этап развития этой окраины в неопротерозое она испытывала поднятие, связанное с процессом сжатия, вызванным движением этой области к северу. Сибирский кратон смещался к югу, испытывая при этом поддвиг под подвижную область [Bulgatov, 2015].

Наиболее интенсивные аккреционно-коллизионные процессы проявились на завершающих этапах развития островодужного магматизма байкалид. Ареалы этого магматизма приурочены к Прибайкальскому и Байкало-Муйскому коллизионно-сдвиговым поясам [Gladkochub, 2004; Tsygankov, 2005]. В их состав входят многочисленные тела синколлизионных ультрамафитмафитов, плагиогранитов, эндербит-аляскитов, метаморфизованные в разной степени вулканогенно-осадочные отложения, превращенные в гнейсы, сланцы и гранулиты. К островодужно-аккреционным образованиям можно отнести гранитоиды муйского, кичерского, бамбукойского комплексов с возрастом 825, 815, 788 млн лет. Они имеют в основном низкие отрицательные величины $\varepsilon_{\mathrm{Nd}}(\mathrm{T})($ (от -8.30 до -0.34) долгоживущих сиалических источников, с Nd модельным возрастом протолитов от 2000 до 1500 млн лет. С завершающими процессами байкальского этапа связаны также складчатость и метаморфизм пород, формирование 
взбросовых и надвиговых структур, покровно-складчатых дуг (Патомская, Средневитимская, Келяно-Ирокиндинская, Каралон-Мамаканская и др.). Осадочновулканогенные комплексы океанических структур, островных дуг, околодуговых турбидитовых бассейнов дислоцированы в крутые линейные складки и метаморфизованы зонально от зеленосланцевой до амфиболитовой фации. Комплексы разной геодинамической природы, аккретированные к Сибирской платформе во второй половине неопротерозоя, а также образованные в это время синколлизионно-синаккреционные комплексы несогласно перекрыты эдиакарий-кембрийскими терригенно-карбонатными неметаморфизованными отложениями (например, холоднинской свиты). Это важное обстоятельство, определяющее возраст аккреции к кратону СФК, сходных по составу и мощности

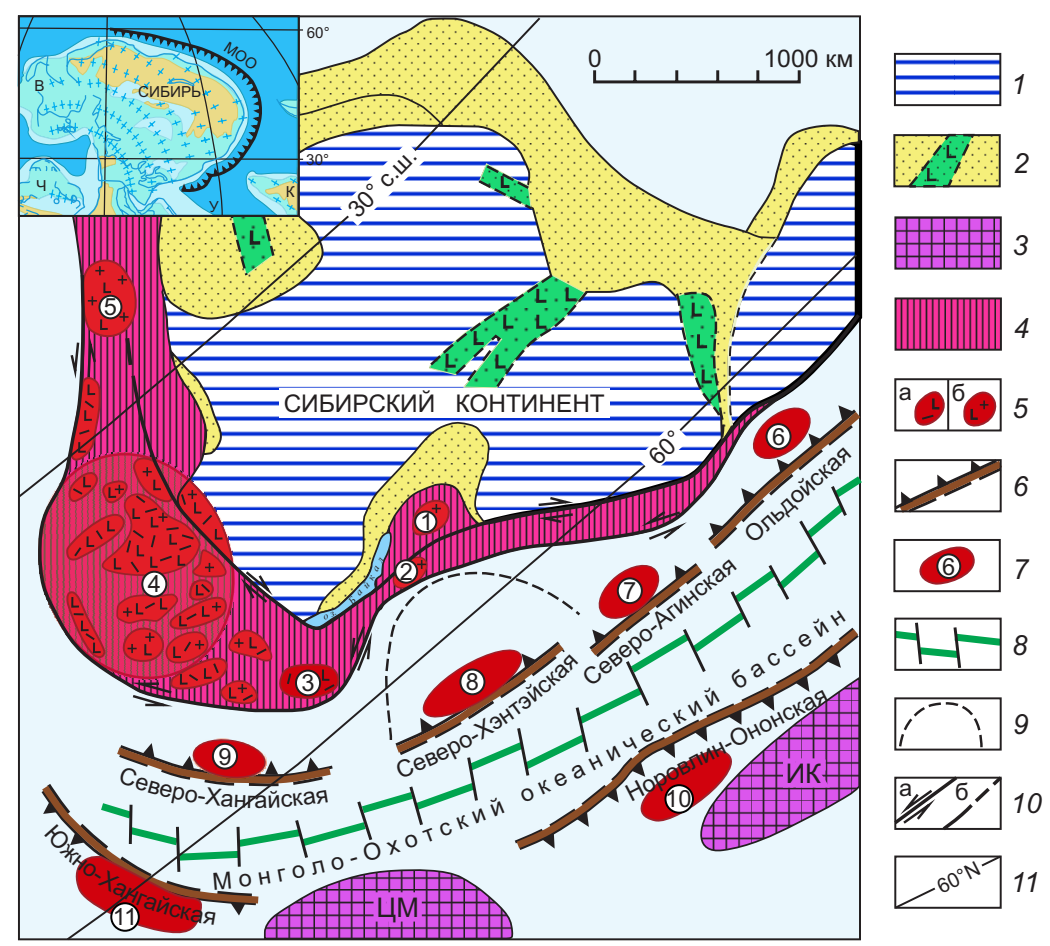

Рис. 8. Палеогеодинамическая реконструкция среднепалеозойской активной окраины Сибирского континента и МонголоОхотского океанического бассейна (по [Gordienko, 2019a], с дополнениями и изменениями).

1 - Сибирский континент; 2 - пассивная окраина континента с внутриплитным магматизмом в рифтовых структурах (авлакогенах); 3 - микроконтиненты (ЦМ - Центрально-Монгольский, ИК - Идэрмэг-Керуленский); 4 - коллаж байкальских и каледонских террейнов различной геодинамической природы в пределах АКО; 5 - ареалы среднепалеозойского внутриплитного магматизма в пределах АКО (1 - Сыннырский, 2 - Сайженский, 3 - Урминский, 4 - Саяно-Минуса-Тувинский, 5 - Кийский): бимодальные вулканические (а) и вулканоплутонические ассоциации (б); 6 - островные дуги с зонами субдукции и субдукционным магматизмом; 7 - ареалы и фрагменты плюмового магматизма в островных дугах и задуговых бассейнах (6 Урушинский, 7 - Уртуйский, 8 - Улан-Баторский, 9 - Тарятский, 10 - Цаганундурский, 11 - Аргалинту); 8 - предполагаемая зона спрединга в Монголо-Охотском океаническом бассейне; 9 - условный контур среднепалеозойского Западно-Забайкальского задугового осадочного палеобассейна (по [Minina et al., 2016]); 10 - разломы: сдвиги (а) и другие разрывные нарушения, в том числе геологические границы (б); 11 - палеошироты Сибирского континента в среднем палеозое. На врезке показана глобальная реконструкция девон-раннекаменноугольного этапа (по [Golonka et al., 2006]). МО0 - Монголо-Охотский океан с протяженной зоной субдукции под Сибирский континент (Сибирь), В - Верхоянский блок, Ч - Чукотский блок, К - Казахстанский микроконтинент, У - Уральский океан.

Fig. 8. Paleogeodynamic reconstructions of the Middle Paleozoic active margin of the Siberian continent and the Mongol-Okhotsk oceanic basin (modified after [Gordienko, 2019a]).

1 - Siberian continent; 2 - passive continental margin with intraplate magmatism in rift structures (aulacogens); 3 - microcontinents (ЦМ - Central Mongolian, ИК - Idermeg-Kherlen); 4 - collage of the Baikal and Caledonian terranes of various geodynamic nature within the active continental margin; 5 - areas of the Middle Paleozoic intraplate magmatism within the active continental margin (1 Synnyr, 2 - Saizhen, 3 - Urmin, 4 - Sayan-Minusa-Tuva, 5 - Kiy): bimodal volcanic (a) and volcano-plutonic associations (б); 6 - island arcs with subduction zones and subduction magmatism; 7 - areas and fragments of plume magmatism in island arcs and back-arc basins (6 - Urusha, 7 - Urtui, 8 - Ulaanbaatar, 9 - Taryat, 10 - Tsagan Undur, 11 - Argalintu); 8 - suggested spreading zone in the MongolOkhotsk oceanic basin; 9 - suggested contour of the Middle Paleozoic West Transbaikalia back-arc sedimentary paleobasin (after [Minina et al., 2016]); 10 - faults: (a) strike-slip faults, (б) other discontinuities, including geological boundaries; 11 - paleolatitudes of the Siberian continent in the Middle Paleozoic. The inset shows the global reconstruction of the Devonian - Early Carboniferous stage (after [Golonka et al., 2006]). MOO - Mongol-Okhotsk oceanic basin with a long subduction zone underneath the Siberian continent (Siberia), B - Verkhoyansk block, Ч - Chukotka block, K - Kazakhstan microcontinent, U - Ural ocean. 
с синхронными отложениями Сибирской платформы [Bulgatov, 2015].

Аккреционно-коллизионные процессы позднебайкальского этапа проявились также среди других неопротерозойских островодужных систем Монголо-Забайкальского региона (Катаевская, Метешихинская, Сонгинская (Холбонурская), Сархойская в Тувино-Монгольском блоке и др.). В их пределах процессы коллизии развивались одновременно или после формирования зон субдукции [Gordienko, 2004, 2006, 2019a; Yarmolyuk et al., 2015, 2017; Kozakov et al., 2003].

Наиболее активно эти процессы проявились в позднекаледонский этап, охватывающий временной интервал от позднего кембрия до ордовика и силур включительно. На рубеже нижнего и среднего кембрия в исследуемом регионе произошла глобальная тектоническая перестройка, выразившаяся в смене направления движения литосферных плит. Сибирский континент, перемещаясь в северном направлении, практически прекратил вращательное движение. Смена направления движения океанических плит по отношению к островодужной системе привела к формированию левосторонних сдвиговых зон в структуре окраины континента [Pechersky, Didenko, 1995; Kungurtsev et al., 2001; Metelkin, 2012]. При этом считается, что массовый гранитоидный магматизм этого этапа связан с процессами аккреции эдиакарий-раннекембрийских океанических и островодужных комплексов с докембрийскими микроконтинентами ЦАСП [Gordienko, 1987, 2006; Kovalenko et al., 2003; Yarmolyuk et al., 2011].

Среди аккреционно-коллизионных СФК наиболее полно исследованы позднекаледонские гранитоиды и дислоцированные осадочные отложения в Джидинской островодужной системе [Gordienko et al., 2007, 2012b]. В Джидинской зоне широко распространены флишоидные терригенно-карбонатные отложения кемброордовика (джидинская свита), с которыми ассоциируют коллизионные гранитоиды позднеджидинского комплекса (Дархинтуйский, Барунгольский, Хулдатский и другие массивы). К настоящему времени получены надежные U-Pb геохронологические данные о позднекембрийском - раннеордовикском возрасте этих массивов

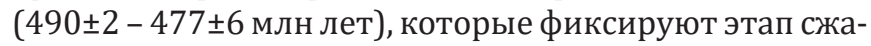
тия Джидинской зоны и превращение ее в покровноскладчатый ороген. Гранитоиды с близким возрастом

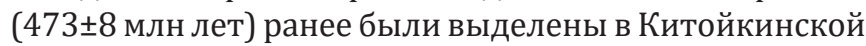
зоне высокометаморфизованных пород Шарыжалгайского выступа, что позволило выделить в Прибайкалье ордовикский коллизионный метаморфический пояс [Donskaya et al., 2000].

Становление вышеназванных массивов коллизионных гранитоидов Джидинской зоны происходило в позднем кембрии - раннем ордовике, что не противоречит полученным к настоящему времени данным о строении и геологическом развитии этой зоны. В среднем кембрии завершилось формирование вначале Джидотского и Ургольского гайотов и затем Джидинской энсиматической (с бонинитами) островной дуги и Джидинская зона вступила в орогенный этап развития. Этот этап характеризуется интенсивными процессами аккреции и коллизии океанических комплексов, островных дуг и микроконтинентов, которые повсеместно проявились в каледонидах восточного сегмента ЦАСП.

$\mathrm{Sm}-\mathrm{Nd}$ изотопные результаты исследований коллизионных гранитоидов Джидинской зоны каледонид не противоречат геологическим данным. Тоналиты Дархинтуйского и Барунгольского массивов имеют положительные или близкие к нулю величины $\varepsilon_{\mathrm{Nd}}(0.49)=$ $=-0.5 \ldots+1.2$ и неопротерозойские $\mathrm{Nd}$ модельные возрасты в узком интервале 1.2-1.0 млрд лет. Наиболее низкую отрицательную величину $\varepsilon_{\mathrm{Nd}}(0.48)=-2.2$ и более древний $\mathrm{Nd}$ модельный возраст $\mathrm{T}_{\mathrm{Nd}}(\mathrm{DM})=1.5$ млрд лет имеет кварцевый монцонит Хулдатского массива. На диаграмме $\varepsilon_{\mathrm{Nd}}(\mathrm{T})$ - возраст фигуративные точки составов изученных гранитоидов находятся между полями эволюции изотопного состава $\mathrm{Nd}$ базальтов офиолитового и островодужного комплексов, островодужных гранитоидов и туфогенных пород хасуртинской свиты Джидинской зоны, с одной стороны, и терригенных осадков джидинской свиты и метатерригенных пород Хамардабанской зоны - с другой [Gordienko et al., 2012b]. Участие в петрогенезисе коллизионных гранитоидов Джидинской зоны источников с длительной коровой предысторией или обогащенных мантийных (плюмовых) источников отражают низкие положительные и отрицательные величины $\varepsilon_{\mathrm{Nd}}(\mathrm{T})$ и неопротерозойские модельные возрасты исследованных гранитоидов. Исходя из геологических, геохимических и $\mathrm{Nd}$ изотопных данных, можно предполагать, что источниками расплавов могли являться, с одной стороны, породы эдиакарий-раннекембрийского офиолитового и островодужного комплексов, а с другой - вмещающие кембро-ордовикские флишоидные отложения джидинской свиты задугового бассейна, а также докембрийские породы Хамардабанской зоны в зоне его сочленения с Джидинской островодужной системой. Таким образом, геологические, геохронологические, геохимические и $\mathrm{Sm}-\mathrm{Nd}$ изотопные данные свидетельствуют о формировании изученных гранитоидов в коллизионной обстановке в рамках модели плавления и деламинации утолщенной в ходе коллизии континентальной коры [Gordienko et al., 2003a].

В пределах Монголо-Забайкальского региона раннекаледонские островодужные системы занимают значительные площади. Среди них, так же как и в Джидинской зоне, проявились позднекаледонские аккреционно-коллизионные процессы с формированием в основном коровых гранитоидов и метаморфических толщ. Подобные аккреционно-коллизионные СФК известны в Присаянской, Удино-Витимской, Ангино-Таланчанской, Таннуольско-Хамсаринской, Керуленской, Озерной, Баян-Хонгорской и других зонах. Однако изучены они недостаточно, чтобы дать их подробную характеристику. Это замечание относится и к герцинскому этапу развития региона. 
Среди герцинских структур Забайкалья и Монголии известны субдукционно-аккреционные комплексы, связанные с формированием островных дуг в пределах спрединговых окраинных морей Монголо-Охотского океанического бассейна. Подобные комплексы встречаются также в виде динамометаморфических куполов и ядер кольдильерского типа, возникших в основном в мезозое в коллизионный этап развития региона [Sklyarov et al., 1994; Gordienko et al., 2018b]. Однако это отдельная тема, которая не обсуждается в данной работе.

\section{3. Роль внутриплитного (плюмового) магматизма в формировании континентальной коры региона}

Проблема внутриплитного (плюмового) магматизма в формировании континентальной коры возникла после появления в начале 60-х годов прошлого столетия новой парадигмы развития Земли - тектоники литосферных плит, когда было установлено, что, наряду с субдукционным магматизмом в островных дугах, одновременно существует плюмовый магматизм, который проявляется как на границах, так и внутри континентальных и океанических литосферных плит [Dietz, 1961; Wilson, 1963; Morgan, 1972; Zonenshayn, Kuzmin, 1983].

Внутриплитный (плюмовый) магматизм по своему объему и интенсивности, несомненно, является важным корообразующим фактором, участвующим в формировании как океанической, так и континентальной коры Центрально-Азиатского складчатого пояса. Среди исследованных островодужных и коллизионных магматических комплексов карельского, байкальского, каледонского и герцинского этапов формирования континентальной коры Монголо-Забайкальского региона всюду присутствует в разном объеме внутриплитный (плюмовый) магматизм. В его составе наблюдаются прежде всего щелочные (щелочно-гранитоидные и щелочно-габброидные) плутонические комплексы, а также щелочные и субщелочные вулканические серии континентальных рифтов, океанических плато и островов (гайотов), а также бимодальные, карбонатитовые, платобазальтовые ассоциации пород. Сюда же относятся разного размера плутоны базитового и базит-ультрабазитового состава и гранитоидные батолиты, не связанные с островодужным и коллизионным магматизмом, но имеющие на заключительных этапах их развития высокие положительные $\varepsilon_{\mathrm{Nd}}(\mathrm{T})$ и $\mathrm{Sm}-\mathrm{Nd}$ отношения магматических источников относительно деплетированной мантии.

В пределах южной окраины Сибирского кратона внутриплитный (плюмовый) магматизм известен начиная с неоархея и палеопротерозоя. Массивы щелочно-гранитоидных и щелочно-базит-ультрабазитовых пород выделены в пределах Алдано-Станового блока (Селигдар - 2038-1844 млн лет, Хани - 1818-1870 млн лет, Верхнесакуканский и Чинейский - 1880-1867 млн лет, Катугинский - 2066-2055 млн лет и др.) и Присаянского блока (Сарматинский и Булунский массивы ультраосновных пород) [Konnikov, 1986; Gladkochub, 2004; Donskaya et al., 2018].

Среди байкальских СФК внутриплитный магматизм проявился в разных объемах практически среди всех выделенных нами неопротерозойских островных дуг Забайкалья, Восточного Саяна и Монголии [Gordienko, 2019a]. Так, в задуговой области неопротерозойской Нюрундуканской островной дуги сформировался крупный Олокит-Довырен-Сыннырский ареал внутриплитного мантийного магматизма протяженностью более 250 км. В основании разреза Олокитского рифта распространена сланцево-метабазальтовая толща океанической стадии развития (базальты E-MORB типа), относящаяся к тыйской свите. Она обнажается по рекам Тыя и Нюрундукан и вдоль Абчадской сдвиговой зоны, ограничивающей рифт с северо-запада. Возраст базальтов 927 и $915 \pm 5$ и млн лет. Базальты Олокитского рифта по вещественному составу отвечают внутриплитным океаническим базальтам [Makrygina et al., 2005; Orsoev et al., 2015]. Их источники $\varepsilon_{\mathrm{Nd}}(\mathrm{T})$ имеют высокие отрицательные значения в пределах от -7.0 до -14.4, с $\mathrm{Nd}$ модельным возрастом протолитов 3460-2431 млн лет. Терригенные турбидиты рифта, мощностью 4-5 км, залегают согласно на метабазальтах океанической стадии. В турбидитах рифта картируются линзы серпентинизированных и меланжированных реститовых гипербазитов [Bulgatov, 2015].

В северной части Олокитского рифта расположен Сыннырский рифтогенный прогиб протяженностью около 200 км при ширине до 12-15 км. В его основании залегают слабоизмененные массивные вулканогенные породы олокитской, сыннырской и условно «иньяптукской» свиты: базальты, диабазы, пикрито-базальты, риолиты и их туфы. Мощность 1500-2000 м. Бимодальный внутриплитный магматизм Сыннырского рифта охарактеризован цифрами абсолютного возраcта (U-Pb метод по циркону): калиевые риолиты 711 млн лет, субщелочные базальты 729 млн лет, кварцевые порфиры 729 млн лет [Ariskin et al., 2013; Rytsk et al., 2011]. Все названные вулканиты, за исключением метабазальтов «иньяптукской» свиты $\left(\varepsilon_{\mathrm{Nd}}(\mathrm{T})=+4.6\right)$, имеют отрицательные значения $\varepsilon_{\mathrm{Nd}}(\mathrm{T})$ в пределах от -8.0 до -13.7, с Nd модельным возрастом протолитов 2074 млн лет. Возраст вулканитов практически совпадает с возрастом кристаллизации Йоко-Довыренского дуниттроктолит-габбрового массива - 728.4 33.4 и 733 млн лет [Ariskin et al., 2013; Orsoev et al., 2018]. Йоко-Довыренский массив является типичным представителем внутриплитного (плюмового) магматизма. В его составе выделяются как ультраосновные породы (дуниты, верлиты), так и породы основного ряда (троктолиты, оливиновые габбро, габбро-нориты и нориты). Эти разновидности пород последовательно сменяют друг друга в разрезе массива снизу вверх. Состав родоначальной магмы Йоко-Довыренского массива отвечает высокомагнезиальному, низкотитанистому пикритобазальту нормальной щелочности. Родоначальный высокомагнезиальный расплав свидетельствует о высоком тепловом 
потоке, вероятно, обусловленном существованием в этот период мантийного плюма, что подтверждается ювенильным источником метабазальтов «иньяптукской» свиты с положительными величинами $\varepsilon_{\text {Nd }}(\mathrm{T})=+4.6$ и неоархейским $\mathrm{Nd}$ модельным возрастом $\mathrm{T}_{\mathrm{Nd}}(\mathrm{DM})$ протолита (2.7-2.8 млрд лет) [Ariskin et al., 2013; Orsoev et al., 2018]. Полученные датировки для вулканитов и интрузивных пород довыренского комплекса свидетельствуют в пользу синхронности проявления иньяптукско-сыннырской фазы вулканизма и мантийных интрузивных процессов при формировании Йоко-Довыренского массива, которые сопровождали раскрытие Сыннырского рифта в задуговой части Нюрундуканской островной дуги.

С магматизмом Метешихинской островодужной системы связано формирование Ольхон-Урбикан-Намаминского задугового ареала внутриплитного мантийного магматизма [Tsydypov et al., 2006; Fedorovsky et al., 2010; Gordienko, 2019a]. Данный ареал субдукционного и связанного с ним плюмового магматизма выделяется нами пока условно. В Ольхонском композитном террейне присутствуют разнообразные по составу габброиды и щелочные сиениты. Большинство значений возраста этих пород относится к кембрию и ордовику.

В задуговой части Метешихинской островной дуги, вдоль восточного побережья озера Байкал присутствует целая полоса северо-восточного направления слабоизученных массивов базитовых и ультрабазитовых пород, иногда повышенной щелочности с апатитовым оруденением [Andreev et al., 1972]. Это Телегинский массив апатитоносных габбро и Урбиканский массив ультрамафит-мафитовых пород, а также расположенная к северо-востоку в верховьях рек Кабанья, Томпуда, Светлая и Намама целая цепочка массивов основных и ультраосновных пород неясного происхождения. В частности, в результате исследований Урбиканского

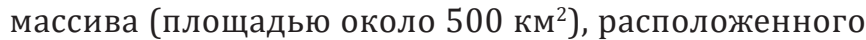
на побережье озера Байкал, было установлено, что в его строении участвует дифференцированная серия пород от плагиоверлитов до габбро-норитов. Юго-восточную часть массива слагают в основном габбро, центральную часть - пироксениты и перидотиты, имеющие постепенные переходы между собой. По геохимическому составу породы массива в целом относятся к высокоглиноземистому типу, а по содержанию $\mathrm{MgO}$ (около $8 \%$ - к средне- и низкомагнезиальным разностям. Возраст Урбиканского массива, определенный ${ }^{40} \mathrm{Ar} /{ }^{39} \mathrm{Ar}$ методом по амфиболам, составляет $750 \pm 6$ млн лет [Тsydypov et al., 2006].

В задуговой части Келянской островодужной системы почти одновременно формировались Каралон-Кедровско-Ирокиндинский и Амалат-Верхневитимский ареалы плюмового магматизма. В Каралон-КедровскоИрокиндинском ареале проявления плюмового магматизма представлены каралонской серией бимодальных вулканитов с возрастом 675 млн лет [Rytsk et al., 2007], а также комагматичных им крупных интрузий габбро-диорит-плагиогранитного состава таллаинского комплекса, сформированного в диапазоне 615-603 млн лет [Rytsk et al., 2018]. Внедрению этих гранитоидов предшествовало образование в пределах северо-восточной части Муйской глыбы Заоблачного массива расслоенных ультрабазит-базитовых пород. Массив сложен двухфазной расслоенной серией, представленной плагиолерцолитами, троктолитами, габбро и габбро-норитами (первая фаза) и оливин-амфиболовыми габбро и габбро-норитами (вторая фаза). По геохимическому составу для пород характерно повышенное содержание титана-магнетита и апатита, обогащение некогерентными элементами, минимум по европию. Sm-Nd возраст габбро-норитов Заоблачного массива (по плагиоклазу, пироксену и апатиту) составляет $612 \pm 62$ млн лет при положительном значении $\varepsilon_{\text {Nd }}(\mathrm{T})=+6.7$, что указывает на ювенильные источники его образования [Izokh et al., 1998]. В Амалат-Верхневитимском ареале плюмового магматизма Келянской энсиматической островодужной системы были сформированы разнообразные слабоизученные базитовые и ультрабазит-базитовые массивы (Устькондинский, Джидотойский, Могойтинский, Амалатский и др.) неопротерозойского возраста [Gordienko, 2019a].

В преддуговой и задуговой части Катаевской дуги сформировался обширный неопротерозой-палеозойский Малхано-Яблоновый ареал субдукционного и плюмового магматизма, представленный целой провинцией разнообразных габброидов и гранитоидов (габбро, габбро-диориты, диориты, габбро-долериты, известково-щелочные граниты, граносиениты, гранодиориты, монцониты), возраст, структурное пложение и петролого-геохимические особенности которых не до конца изучены. Судя по палеореконструкции (см. рис. 6), этот ареал продолжает Амалат-Верхневитимскую группу массивов плюмового магматизма в задуговой части Келянской островодужной системы. По-видимому, именно этот магматизм в дальнейшем способствовал заложению эдиакарий-раннекембрийского Забайкальского спредингового бассейна ПАО [Gordienko, 2006, 2019a].

Наиболее ярко внутриплитный магматизм проявился в каледонских островодужных системах, сформированных на активных континентальных окраинах западно-тихоокеанского типа в пределах ПАО.

Так, в пределах Джидинской энсиматической островной дуги на начальном этапе образовалась ассоциация океанических островов и плато (гайотов), сформированных на коре океанического типа (базит-гипербазиты Бугуриктайского массива с U-Pb возрастом $560 \pm 5$ млн лет) [Elbaev et al., 2018] на значительном удалении от островной дуги [Gordienko, Mikhal'tsov, 2001]. Нижний комплекс Джидотского симаунта (гайота) представлен подушечными лавами низкотитанистых толеитовых базальтов, средний комплекс сложен толщей субщелочных высокотитанистых вулканитов основного и среднего состава с телами известняков и силицитов, а верхний комплекс сформирован карбонатной толщей с преобладанием доломитов (карбонатная платформа) с участием субщелочных вулканокластических 
пород (хасуртинская свита). Океанические базальты Джидотского гайота имеют эдиакарский возраст и высокие положительные величины $\varepsilon_{\mathrm{Nd}}(560)=+9.2,+6.4,+3.5$ ювенильной коры, близкой по составу к обогащенной DM [Gordienko, 2019a]. В Джидинской задуговой зоне произошло формирование Шильдырхейского и Хоштогольского габброидных массивов повышенной щелочности средне- и верхнекембрийского возраста (U-Pb метод, соответственно 495 и 508 млн лет). По сравнению с базальтами гайота в них величина $\varepsilon_{\mathrm{Nd}}(560)$ также положительная, но немного пониженная (+0.22 и +3.75), близкая к DM океанической коры. Nd модельный возраст протолитов коры $\mathrm{T}_{\mathrm{Nd}}(\mathrm{DM})$ мезонеопротерозойский - от 1521 до 929 млн лет.

Петролого-геохимические исследования субщелочных базальтов джидинских гайотов хорошо сопоставляются с океаническими платобазальтами поднятия Онтонг-Джава и гайота Кастор, а также с палеогайотами Озерной и Баян-Хонгорской зон Монголии [Kovalenko et al., 2005; Kovach et al., 2005; Yarmolyuk et al., 2013] и Алтае-Саянской области [Dobretsov et al., 2004; Simonov et al., 2014; Safonova et al., 2011] и многих других районов, связанных с раннекаледонским островодужным магматизмом. Так, плюмовый магматизм в Баян-Хонгорской островной дуге, так же как и в Джидинской, предшествовал островодужному магматизму с образованием крупных океанических плато (гайотов), но имел более древний U-Pb возраст - 665 15 млн лет, также с высоким положительным значением источников $\varepsilon_{\mathrm{Nd}}(665)=+9.8$ ювенильной коры, близкой к обогащенной DM [Kovach et al., 2005; Kovalenko et al., 2005].

В меньшей степени проявлен внутриплитный магматизм в энсиалических островных дугах исследованного региона - Ангино-Таланчанской и Удино-Витимской. Так, щелочные сиениты и нефелиновые сиениты Тажеранского щелочно-базитового массива с U-Pb возрастом соответственно $471 \pm 5$ и $451 \pm 1,464 \pm 2$ млн лет относятся к типично плюмовому магматизму позднекаледонской Ангино-Таланчанской островодужной системы. К этому же магматизму относятся необычные карбонатиты Тажеранского массива с близким возрастом 466 2 млн лет [Sklyarov et al., 2009; Fedorovsky et al., 2010; Dobretsov, 2011a].

В задуговой зоне Удино-Витимской островной дуги, наряду со среднеордовикским известково-щелочным вулканизмом (базальты, андезиты, трахириолиты) $470.4 \pm 3.8$ и 466.1 \pm 3.6 млн лет (U-Pb возраст по цирконам, Ульдзутуйский ареал) [Ruzhentsev et al., 2012], произошло более раннее внедрение крупных массивов позднекембрийско-раннеордовикских щелочных пород (нефелиновых сиенитов, ийолит-уртитов) сайженского комплекса (Витимский ареал) с U-Pb возрастом 520486 млн лет [Doroshkevich et al., 2011], а также более поздних раннесилурийских Ингодинского и Малангинского габброидных расслоеных массивов Центрального Забайкалья с U-Pb возрастом 430 и 440 млн лет соответственно. Среди них выделяется крупный расслоенный Ингодинский массив с U-Pb возрастом троктолитов
$440 \pm 20$ млн лет. Он имеет Nd модельный позднекембрийский возраст протолита $\mathrm{T}_{\mathrm{Nd}}(\mathrm{DM}-2 \mathrm{st})=504-571 \mathrm{MлH}$ лет и высокие положительные величины $\varepsilon_{\mathrm{Nd}}(\mathrm{T})$ от +7.49 до +8.24, указывающие на ювенильные источники его формирования, близкие к обогащенной DM. Подобные источники имеют малангинские габброиды, а также коллизионные гранитоиды Малханского и Югальского массивов Центрального Забайкалья с U-Pb возрастом 430 и 440 млн лет и положительными величинами $\varepsilon_{\mathrm{Nd}}(\mathrm{T})$ от +2.52 до +1.85. Однако $\mathrm{Nd}$ возраст их протолитов $\mathrm{T}_{\mathrm{Nd}}(\mathrm{DM}-2 \mathrm{st})$ является ранненеопротерозойским (1049-1001 млн лет).

Таким образом, на примере каледонских энсиматических и энсиалических островных дуг можно проследить все основные этапы их эволюции от плюмового магматизма с формированием ОІВ (симаунты, гайоты), типичного субдукционного магматизма с бонинитами до развитого андезит-риолитового и гранитоидного островодужного магматизма с формированием мощных толщ туфотурбидитов и ареалов внутриплитного щелочного магматизма на заключительной стадии. Каледонская континентальная кора в Монголо-Забайкальском регионе образовалась в основном за счет аккреционно-коллизионных и внутриплитных преобразований островных дуг, океанических островов и плато, окраинных осадочных бассейнов ПАО и фрагментов докембрийских микроконтинентов.

На раннегерцинском этапе на активной окраине Сибирского континента, особенно его западной части (в современных координатах), в условиях рассеянного рифтогенеза проявились мощные тектономагматические процессы, приведшие к формированию СаяноМинуса-Тува-Монгольского ареала плюмового магматизма, где сосредоточены огромные массы щелочных и субщелочных вулканических пород, которые ассоциируют с разнообразными комагматичными им интрузивными комплексами. При этом бимодальные серии повышенной щелочности и щелочные часто перемежаются, а иногда развиты в одних и техже структурах [Gordienko, 1987; Vorontsov et al., 2015]. Так, в Окинском районе юго-восточной части Восточного-Саяна сформировалась крупная Урда-Хойто-Окинская рифтогенная вулканоплутоническая структура, в которой сосредоточена трахириолит-комендит-щелочно-гранитовая с нефелиновыми сиенитами ассоциация пород нижнедевонского возраста [Gordienko, 1969, 1987, 2019а].

В это время в Южном Прибайкалье сформировался девонский осадочно-вулканогенный Урминский рифтогенный прогиб [Gordienko et al., 2003b]. Подобные морские присдвиговые бассейны типа пулл-апарт (Багдаринский, Уакитский и др.) образовались в Западном Забайкалье, где они являются реликтовыми прогибами крупного позднедевонского палеобассейна [Gordienko et al., 2004; Minina et al., 2016], образованного на границе АКО Сибирского континента и Хангай-ХэнтэйАгинской системы островных дуг и окраинных морей Монголо-Охотского океанического бассейна. В тылу АКО отмечается разнообразный щелочной магматизм 
в Южном Прихубсугулье [Yashina, 1982] и Северном Прибайкалье (Сыннырский и Сайжинский ареалы), что связано с зарождением средне- и верхнепалеозойских плюмов [Gordienko, 2019a].

В пределах Западного и Центрального Забайкалья выявлен обширный ареал герцинского внутриплитного плюмового магматизма, представленный целой провинцией повышенной щелочности вулканогенных толщ, габброидных и гранитоидных ассоциаций (Приложение 1 ; см. рис. 4, 5). Все они в основном имеют рифтогенную природу. Среди вулканогенных толщ изучены бимодальные серии (базальты, риолиты и трахириолиты уендэктской толщи), метадолериты и метаандезиты ципиканской толщи, андезибазальты и трахириолиты точерской свиты. Их возраст колеблется от 407 (ранний девон) до 324 (ранний карбон) млн лет [Ruzhentsev etal., 2012; Minina et al., 2016]. По изотопным данным они имеют неодинаковые отрицательные величины $\varepsilon_{\text {Nd }}($ T) от -13.74 и -11.20 (уендэктская), -10.95 и -4.15 (ципиканская) до -3.90 (точерская), указывающие на смешанные мантийно-коровые источники. Их Nd модельные возрасты $\mathrm{T}_{\mathrm{Nd}}(\mathrm{DM})$ и $\mathrm{T}_{\mathrm{Nd}}(\mathrm{DM}-2 \mathrm{st})$ относятся к палеопротерозою (2287-2094, 2331-1441, 1920-1415 млн лет) соответственно. Преобладающие габброидные ассоциации (атарханский, арсентьевский, оронгойский, альбитуйский, шарагольский, урлукский и другие комплексы) образуют в Забайкалье шесть крупных ареалов, в которых сосредоточено около 80 массивов общей площадью около 200 км². По составу и возрасту они образуют единую серию от 370 (поздний девон) до 250 (поздняя пермь) млн лет [Gordienko et al., 2012a, 2012c]. По $\mathrm{Nd}$ изотопным данным большинство массивов субщелочных габброидов имеют положительные величины $\varepsilon_{\mathrm{Nd}}(\mathrm{T})=+8.02 \ldots+4.34$ и $+2.58 \ldots+2.80$ и только отдельные - низкие отрицательные значения $(-0.72 \ldots-0.19)$. Гранитоидные ассоциации в этом ареале представлены витимканским комплексом (Баунтовский, Ушминский, Ундинский и другие массивы), который по $\mathrm{Nd}$ изотопным данным имеет отрицательные величины $\varepsilon_{\mathrm{Nd}}(\mathrm{T})=$ $=-11.5 \ldots-5.0$, указывающие на корово-мантийные источники. Nd модельный возраст протолитов $\mathrm{T}_{\mathrm{Nd}}(\mathrm{DM})$ и $\mathrm{T}_{\mathrm{Nd}}(\mathrm{DM}-2 \mathrm{st})$ имеет мезонеопалеопротерозойский возраст в пределах 1756-1472 и 2013-1210 млн лет соответственно. Все эти внутриплитные гранитодные ассоциации Забайкалья входят в состав Ангаро-Витимского батолита [Ruzhentsev et al., 2012].

Гранитоидный внутриплитный магматизм герцинского (позднепалеозойского) этапа заслуживает особого внимания, в силу своего необычайно широкого распространения на территории Монголо-Забайкальского региона, где было сформировано несколько крупных гранитоидных батолитов, прежде всего Ангаро-Витимского в Забайкалье и Хангайского в Монголии, а также поясов и ареалов щелочного магматизма в рифтогенных структурах по обрамлению этих батолитов.

В Забайкалье было установлено, что на уровне современного эрозионного среза разнообразные гранитоиды занимают порядка 80 \%. При этом подавляющая часть этих гранитов сформировалась в конце карбона - начале перми (325-275 млн лет назад), образовав один из крупнейших в мире Ангаро-Витимский гранитоидный батолит (ареал-плутон) площадью свыше

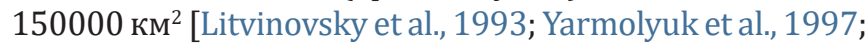
Tsygankov et al., 2010, 2017a, 2017b]. На раннем этапе (325-290 млн лет) происходило внедрение «коровых» известково-щелочных гранитов баргузинского комплекca, несколько позже (305-285 млн лет назад) началось синхронное формирование двух магматических ассоциаций, различающихся набором пород и их петрологогеохимическими характеристиками: высококалиевые известково-щелочные кварцевые монцониты, кварцевые сиениты (чивыркуйский комплекс) и переходные от известково-щелочных к субщелочным лейкограниты и кварцевые сиениты (зазинский комплекс). Обе ассоциации сопровождались синплутоническими базитовыми интрузиями и комбинированными дайками, гранитоиды часто содержат мафические включения, что в совокупности с промежуточными изотопными характеристиками пород указывает на смешанный мантийно-коровый источник салических магм. На следующем этапе в интервале 285-278 млн лет формировались породы высококалиевой серии - кварцевые сиениты и монцониты, часто дифференцированные до субщелочных гранитов, обогащенные калием габброиды (нижнеселенгинский комплекс), а за ними со значительным перекрытием во времени (281-278 млн лет) - щелочные и щелочно-полевошпатовые сиениты и граниты (раннекуналейский комплекс), которые, в отличие от всех предыдущих гранитоидных ассоциаций, сопровождались трахибазальтами, трахитами и трахириолитами, образующими лавовые покровы и дайковые пояса. Продукты щелочно-салического и щелочно-базитового магматизма в виде сотен разновеликих плутонов гранитоидов А-типа и небольших лавовых полей группируются в полосу северо-восточного простирания, известную как Монголо-Забайкальский или СеленгиноВитимский вулканоплутонический пояс, формирование которого продолжалось, возможно с перерывами, с позднего карбона - перми до конца триаса [Gordienko, 1987; Gordienko, Tsygankov, 2017]. По изотопным данным гранитоиды ранних этапов (330-290 млн лет) АнгароВитимского батолита образуют компактную группу пород на диаграмме $\varepsilon_{\mathrm{Nd}}(\mathrm{T})$ - возраст с отрицательными величинами в пределах $-8.47 . . .-11.92$ и средним Nd модельным возрастом протолитов $\mathrm{T}_{\mathrm{Nd}}(\mathrm{DM})$ и $\mathrm{T}_{\mathrm{Nd}}(\mathrm{DM}-2 \mathrm{st})=$ $=1700$ и 2050 млн лет в пределах мезонеопротерозойской изотопной провинции (Приложение 1 ; см. рис. 4, 5, рис. 9). Щелочные породы более поздних этапов (280250 млн лет) рифтогенного происхождения, включенные в состав батолита, имеют положительные $\varepsilon_{\mathrm{Nd}}(\mathrm{T})$ характеристики, близкие к DM, и образуют отдельный ареал с ювенильными источниками [Tsygankov et al., 2010, 2017a, 2017b].

Хангайский батолит возник в поздней перми - раннем триасе в интервале 270-240 млн лет назад. Он является крупнейшим (>150 тыс. км²) скоплением гранитных 
плутонов в Центральной Монголии, состав которых определяют граниты нормального ряда щелочности, в меньшей степени - субщелочные граниты и еще более ограниченно - щелочные граниты [Yarmolyuk et al., 2016]. Батолит является основной частью более крупной Хангайской зонально построенной магматической области, включающей также обрамляющие батолит рифтовые зоны с щелочным магматизмом. В составе батолита преобладают гранодиориты и граниты, а также подчиненные им тоналиты, кварцевые диориты и габбродиориты. Преобладают массивы двухфазного строения. Раннюю фазу представляют гранодиориты с подчиненными кварцевыми диоритами и тоналитами, вторая фаза является собственно гранитной. Гранитоиды комплекса в своих типичных представителях довольно однообразны. В ассоциации с гранитоидами батолита встречаются синплутонические породы основного и среднего состава, проявленные в виде даек, штоков и небольших тел. Для них типичны зоны минглинга на контактах с гранитоидами, которые свидетельствуют о взаимодействии базитовых и гранитных расплавов. Особо следует отметить участие в строении батолита щелочных гранитов. В строении Хангайского батолита рассматриваются несколько ассоциаций пород. Среди них преобладают породы хангайского комплекса, представленные гранитоидами нормального ряда щелочности. Второй по распространенности группой пород являются субщелочные лейкократовые граниты шараусгольского комплекса [Fedorova, 1977; Yarmolyuk et al., 2013, 2016].

\section{5. ОБСУЖДЕНИЕ РЕЗУЛЬТАТОВ}

В данной работе основное внимание было сосредоточено на оценке роли островодужных и тесно связанных с ними океанических комплексов, а также аккреционно-коллизионных и внутриплитных (плюмовых) процессов в формировании континентальной коры Монголо-Забайкальского региона.

Установлено, что все эти процессы были взаимосвязаны и взаимообусловлены. Зоны спрединга в океанах и окраинноморских океанических бассейнах были тесно связаны с образованием зон субдукции и островодужным магматизмом. С другой стороны, коллизионные процессы активно участвовали в формировании аккреционных призм, вулканических построек и способствовали образованию син- и постколлизионных гранитоидов. Было выявлено, что на всех этапах в формировании континентальной коры Монголо-Забайкальского региона активно участвовали внутриплитные (плюмовые) процессы.

Механизмы тектоники литосферных плит и глубинной геодинамики стали проявляться начиная с неоархея, но наиболее активно - в неопротерозое и раннем палеозое в связи с распадом суперконтинента Родиния и образованием Палеоазиатского океана. Было выявлено, что максимальные положительные значения величин $\varepsilon_{\mathrm{Nd}}(\mathrm{T})$ для всех изученных базитов надсубдукционных офиолитов Монголии и Забайкалья вполне удовлетворительно совпадают с линией изотопной эволюции DM, хотя и бывают некоторые отклонения [Коvalenko et al., 1999, 2006; Yarmolyuk et al., 1999, 2002, 2016; Kovach et al., 2011].

Среди мезопротерозойских островодужных систем исследованного региона проанализированы с разной степенью детальности Нюрундуканская и Дунжугурская островные дуги, сформированные соответственно

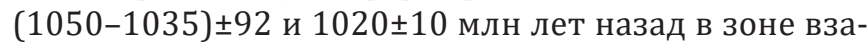
имодействия Сибирского континента и древних океанических бассейнов [Rytsk et al., 2001; Khain et al., 2002]. Согласно палеореконструкциям они сформировались до распада суперконтинента Родиния и формирования Палеоазиатского океана [Kheraskova et al., 2014]. В peзультате тектономагматической деятельности названных островных дуг были сформированы грандиозные складчатые сооружения, которые внесли значительный вклад в становление современной мощной (свыше 50-70 км) континентальной земной коры СаяноБайкальской области [Turutanov, 2011].

При образовании Нюрундуканской дуги был сформирован островодужный комплекс, сложенный мощными (свыше 2000 м) толщами метабазальтов, метадолеритов и метагаббро с высокими положительными параметрами $\varepsilon_{\mathrm{Nd}}(1050)-$ от + 7.9 до +5.5 , указывающими на ювенильные источники их формирования, близкими к DM, крупным Нюрундуканским массивом базитультрабазитовых пород, которые совместно с вулканитами образуют офиолитовую ассоциацию [Tsygankov, 2005]. В фундаменте Нюрундуканской дуги сформировалась мощная (около 5000 м) толща метатерригенных и метатерригенно-карбонатных пород с редкими горизонтами вулканитов кичерской свиты с коровыми величинами $\varepsilon_{\mathrm{Nd}}(950)=-17.8$ и архейскими протолитами $\mathrm{T}_{\mathrm{Nd}}(\mathrm{DM})=3430-2829$ млн лет. Развитие Нюрундуканской дуги, возможно, связано с заложением к югу от нее еще до формирования ПАО (см. рис. 6) Баргузино-Витимского спредингового океанического бассейна, фиксируемого офиолитами (972 млн лет) Шаманской зоны [Nekrasov et al., 2007; Gordienko et al., 2009] и толеитовыми базальтами N-MORB типа асынской толщи (953 млн лет), обнаруженными в верховье р. Турка [Doronina et al., 2013].

На поздней стадии развития Нюрундуканской островной дуги с перерывом около 100-120 млн лет была сформирована крупная Сыннырская рифтовая структура с мощным плюмовым (внутриплитным) магматизмом. Этому событию предшествовало прекращение (стагнация) субдукционных процессов в островодужной системе, переплавление остатков слэбов и погружение их в нижнюю мантию на границе с внешним ядром, что в дальнейшем способствовало возникновению плюмов и формированию внутриплитного магматизма в рифтовой зоне [Gordienko et al., 2019b]. Начальные стадии развития этой зоны связаны с образованием бимодальной базальт-риолитовой серии с возрастом 730-711 млн лет (сыннырская, олокитская, иньяптукская свиты), с $\varepsilon_{\mathrm{Nd}}(\mathrm{T})=-13.7 . . .-8.0$ и $\mathrm{Nd}$ модельным мезопротерозойским 
возрастом $\mathrm{T}_{\mathrm{Nd}}(\mathrm{DM})=2070$ млн лет. С данной структурой связано образование крупного довыренского ультрамафит-мафитового комплекса магматических пород (728-707 млн лет) мантийного происхождения. В формировании этих пород значительное участие принимали также смешанные корово-мантийные источники, о чем говорят отрицательные величины $\varepsilon_{\mathrm{Nd}}(\mathrm{T})=-15.8 \ldots$ -14.1 и древний $\mathrm{Nd}$ модельный возраст протолитов (2.8-2.7 млрд лет). В целом, нюрундуканский островодужный и сыннырский внутриплитный магматизм по $\mathrm{Nd}$ изотопным данным образует непрерывный ареал в пределах карельской и байкальской изотопных провинций (рис. 9).

Другая цепочка неопротерозойских островных дуг: Келянская (830-815 млн лет), Метешихинская (839809 млн лет), Катаевская (893-850 млн лет) связаны с байкальским этапом развития Баргузино-Витимского океанического бассейна и в последующем - с формированием окраинных структур ПАО. В результате деятельности этих дуг и взаимосвязанных с ними коллизионных и внутриплитных процессов были также сформированы крупные покровно-складчатые структуры, сыгравшие главную роль в формировании континентальной коры региона. На диаграммах $\varepsilon_{\mathrm{Nd}}(\mathrm{T})$ и $\mathrm{T}_{\mathrm{Nd}}(\mathrm{DM})$ - возраст (см. рис. 5; рис. 9) они совместно с коллизионными и внутриплитными комплексами образуют обширный ряд значений в основном в пределах мезонеопротерозойской континентальной коры.

На каледонском этапе (эдиакарий - нижний палеозой) в результате заложения и развития спрединговых океанических бассейнов, океанических островов (гайотов), активных континентальных окраин, островных дуг энсиалического (Ангино-Таланчанская, Удино-Витимская) и энсиматического (Джидинская, Таннуольско-Хамсаринская, Баян-Хонгорская, Озерная) типа на окраинах Палеоазиатского океана произошло дальнейшее активное формирование континентальной коры региона [Gordienko, 2006, 2019a; Yarmolyuk et al., 1999, 2002, 2006; Kovach et al., 2011]. На диаграмме $\varepsilon_{\text {Nd }}($ T) - возраст (см. рис. 5; рис. 9) все проанализированные породы

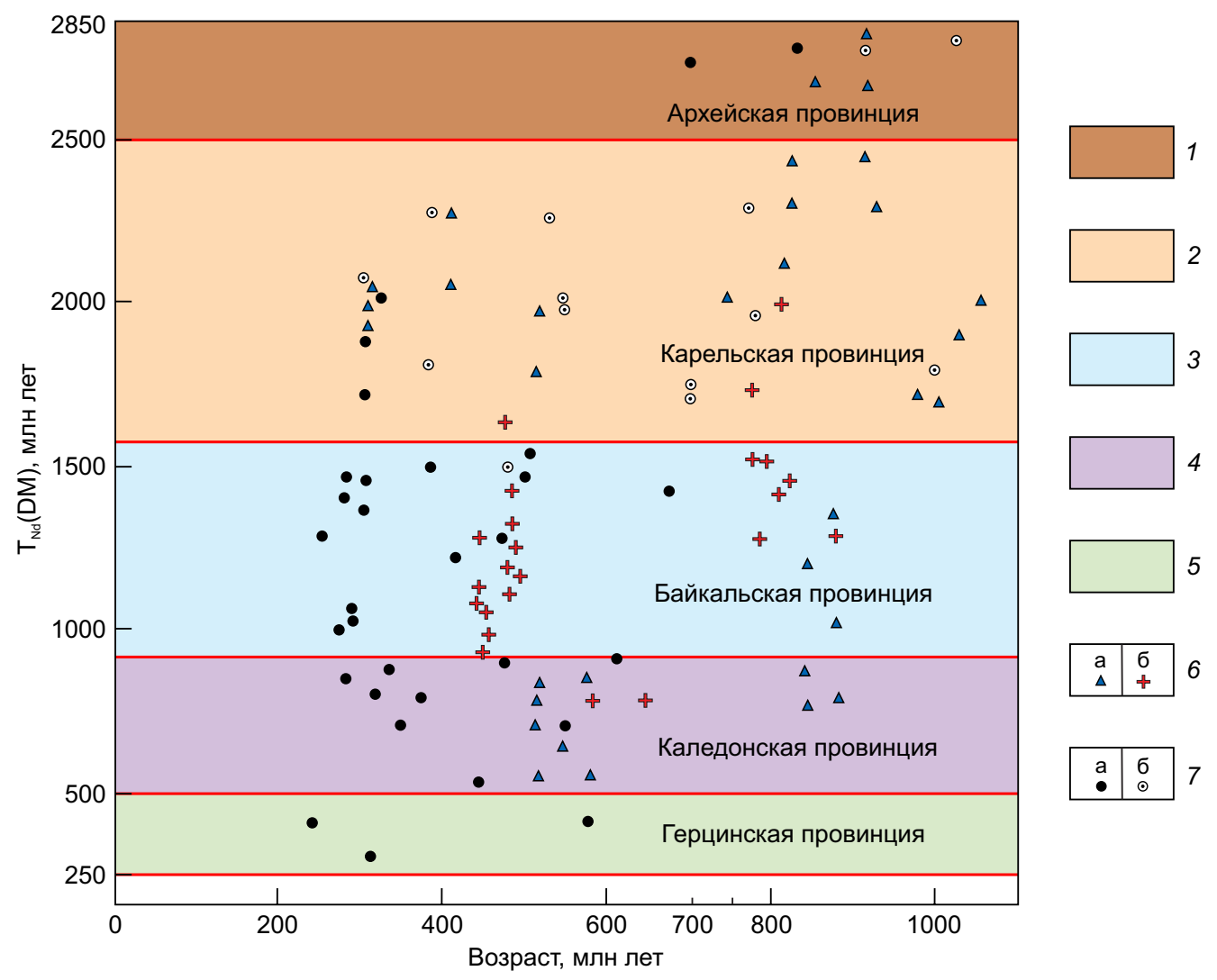

Рис. 9. Диаграмма размещения Nd модельных возрастов $\mathrm{T}_{\mathrm{Nd}}(\mathrm{DM})$ по отношению к возрасту магматических и осадочных пород островодужного, коллизионного и внутриплитного типа в изотопных провинциях Монголо-Забайкальского региона.

Изотопные провинции континентальной коры и Nd модельные возрасты их формирования (Приложение 1; см. рис. 4, 5, рис. 9): 1 - архейская, 2 - карельская, 3 - байкальская, 4 - каледонская, 5 - герцинская, 6-7 - магматические и метаосадочные породы различных генетических и геодинамических типов: 6 - островодужные (a), коллизионные (б), 7 - внутриплитные (а), осадочных бассейнов (б).

Fig. 9. Distribution diagram of Nd model ages, $\mathrm{T}_{\mathrm{Nd}}(\mathrm{DM})$ compared to the ages of igneous and sedimentary rocks of island-arc, collisional and intraplate types within the isotope provinces of the Mongolia-Transbaikalia region.

Isotope provinces of continental crust and their Nd model ages (see Appendix 1; Figs. 4, 5, 9): 1 - Archean, 2 - Karelian, 3 - Baikal, 4-Caledonian, 5 - Hercinian, 6-7 - igneous and metasedimentary rocks of various genetic and geodynamic types: 6-island-arc (a), collisional (б), 7 - intraplate (a), sedimentary basins (б). 
этих дуг образуют непрерывный вертикальный ряд положительных значений с мантийными метками преимущественно в пределах каледонской с частичным переходом в область мезонеопротерозойской и герцинской континентальной коры. Характерной особенностью энсиматических дуг являлось образование на начальной стадии (эдиакарий) развития дуги океанических островов и плато (гайотов) с последующим формированием (ранний кембрий) надсубдукционных магматических комплексов с участием бонинитов и известково-щелочных дифференцированных вулканических серий. В этих процессах активное участие принимал плюмовый магматизм. В ордовике и силуре четко проявлен коллизионный этап развития поздних каледонид с внедрением гранитоидов со смешанными корово-мантийными источниками.

На герцинском этапе в Забайкалье и Монголии широко проявились как субдукционные, так и внутриплитные магматические процессы, связанные с мантийными плюмами [Yarmolyuk et al., 2013; Gordienko, 2019a]. В результате многолетних исследований нами был выделен и частично изучен целый ряд фрагментов раннегерцинских островных дуг (Северо-Хангайская, СевероХэнтэйская, Северо-Агинская (Береинская), Уртуйская, Ольдойская, Адацагская, Норовлин-Ононская, ЮжноГобийская), океанических островов и плато (гайоты), связанных с развитием Монголо-Охотского океанического бассейна и его активных континентальных окраин [Gordienko et al., 2010, 2012d, 2018b, 2019b]. Кроме того, на исследованной территории выделена крупная позднегерцинская провинция внутриплитных (плюмовых) магматических пород верхнего девона - карбона перми и раннего триаса. В пределах этой провинции на территории Забайкалья произошло массовое формирование щелочных пород вулканоплутонических поясов и гранитоидов Ангаро-Витимского батолита [Tsygankov et al., 2010, 2017a], а в Монголии - образование Хангайского гранитоидного батолита и окружающих ареалов щелочного магматизма в рифтогенных структурах [Yarmolyuk et al., 2016].

При изучении магматических пород Ангаро-Витимского батолита было установлено, что позднепалеозойские гранитоиды, прежде всего баргузинского комплекса, сформировались на коре континентального типа (имеют коровые источники в основном в пределах мезонеопротерозойской изотопной провинции). Было выявлено, что данная провинция гетерогенна по своей геологической и изотопной структуре, что отражается на изотопном составе более поздних однотипных и одновозрастных гранитоидов. Установлено, что пространственно сближенные, синхронные и сходные по химическому составу, но изотопно разные гранитоиды формировались за счет разноглубинных и разновозрастных источников мезонеопротерозоя $\left(\mathrm{T}_{\mathrm{Nd}}(\mathrm{DM}) \approx 2.0-1.7\right.$ млрд лет) в основном корово-мантийного происхождения [Tsygankov et al., 2010, 2017a, 2017b]. Согласно гравиметрическим данным, АнгароВитимский гранитоидный батолит образует мощную тектоническую пластину лакколитообразной формы с субгоризонтальной кровлей и сложно построенной подошвой, уходящей на глубину в среднем 8-10 км, а в отдельных случаях (р. Конкудера) до 30 км, не выходя за пределы мощности современной земной коры 40-45 км в Северном Прибайкалье [Turutanov, 2011]. Этот факт имеет принципиальное значение для определения древнего возраста континентальной коры под крупнейшим в мире внутриплитным гранитоидным батолитом.

Изотопные данные по гранитоидам Хангайского батолита имеют большой диапазон величин $\varepsilon_{\mathrm{Nd}}(260)-$ от -3.1 до -12.6 [Yarmolyuk et al., 2016]. Высокие отрицательные значения указывают на определенную роль коровой контаминации при формировании гранитоидов. Считается, что это связано с участием окружающих докембрийских блоков (Тарбагатайского и Дзабханского) в процессе формирования континентальной коры с палеопротерозойским Nd модельным возрастом протолитов $\mathrm{T}_{\mathrm{Nd}}(\mathrm{DM})$ и $\mathrm{T}_{\mathrm{Nd}}(\mathrm{DM}-2 \mathrm{st})=1363$ и 1174 млн лет соответственно. Высокое положительное значение $\varepsilon_{\text {Nd }}(240)=+8.0$ указывает на участие в образовании магматических пород батолита зональных ареалов щелочных вулканических и плутонических серий рифтогенного присхождения, что характерно также для АнгароВитимского батолита [Tsygankov et al., 2017b].

Позднепалеозойско-раннемезозойская эпоха является заключительной в истории развития ЦентральноАзиатского и Монголо-Охотского складчатых поясов. Она началась вслед за аккрецией всего комплекса герцинид к окраине Сибирского континента. Эта часть континента практически сразу подвергалась переработке в режиме АКО. В это время проявилась интенсивная внутриплитная активность, которая привела к образованию позднепалеозойско-раннемезозойской рифтовой системы Центральной Азии в форме прогрессивного перемещения зон рифтогенеза от окраины в глубь складчатых поясов. Смена режима конвергентных границ режимом рифтогенеза и внутриконтинентальной коллизии стала следствием перекрытия континентом горячих точек мантии, существовавших до этого в пределах Палеоазиатского океана [Yarmolyuk et al., 2008; Kuzmin et al., 2010; Gordienko et al., 2019b].

\section{6. ЗАКЛЮЧЕНИЕ}

На основе структурно-геологических, геохронологических и $\mathrm{Sm}-\mathrm{Nd}$ изотопных данных определены коровые и мантийные источники магматизма, выделены изотопные провинции и показана роль островодужноокеанических, аккреционно-коллизионных и внутриплитных взаимосвязанных процессов в образовании континентальной коры Монголо-Забайкальского региона. Проведенные геохронологические и Sm-Nd исследования магматических и осадочно-вулканогенных пород Забайкалья и Монголии, с учетом работ предшественников, позволяют предложить следующую историю формирования континентальной коры изученного региона. 
1. Механизмы тектоники литосферных плит и глубинной геодинамики начали проявляться уже на ранней стадии развития Земли, а именно в карельский этап. Считается, что океаническая кора ЦентральноАзиатского складчатого пояса образовалась в это время при частичном плавлении DМ и участии более обогащенной DM, при явных признаках внутриплитной активности мантийных плюмов. Установлено, что в палео- и мезопротерозойских источниках магматических комплексов присутствуют главным образом переработанные блоки древней континентальной коры суперконтинента Колумбия и ее активных и пассивных окраин с высокими отрицательными величинами $\varepsilon_{\mathrm{Nd}}(\mathrm{T})$ ареалов плюмового магматизма (например, базит-ультрабазиты Довырена и метабазальты тыйской свиты) и неоархей-палеопротерозойским Nd модельным возрастом протолитов. Они тяготеют в основном к Байкало-Патомской, Присаянской и Прибайкальской окраинам Сибирского кратона, а также встречаются в виде древних блоков (например, Байдарикский) во внутренней части Центрально-Азиатского складчатого пояса в пределах выделенной карельской изотопной провинции.

2. В последующем, на байкальском этапе (мезонеопротерозое), в структуре байкалид, наряду с остатками древних островных дуг и коровых блоков Родинии, образовались зрелые неопротерозойские островодужные системы (Келянская, Метешихинская, Катаевская, Сонгинская, Сархойская и др.) и окраинноморские бассейны, связанные с формированием активных окраин Палеоазиатского океана. Этот этап фиксируется корово-мантийным и мантийным магматизмом с положительными величинами $\varepsilon_{\mathrm{Nd}}(\mathrm{T})$, указывающими на ювенильные или смешанные источники магматических пород в пределах байкальской изотопной провинции. Протолиты $\mathrm{T}_{\mathrm{Nd}}(\mathrm{DM}-2 \mathrm{st})$ этого этапа имеют в основном мезонеопротерозойский возраст, широко распространены в регионе и участвуют в формировании не только байкалид, но также каледонид и герцинид. В конце байкальского этапа был сформирован коллизионный пояс байкалид преимущественно с неопротерозойской континентальной корой.

3. На раннекаледонском этапе (эдиакарий-кембрий) в результате заложения и развития спрединговых океанических бассейнов, океанических плато (гайоты) и островных дуг энсиалического типа (Удино-Витимская, Ангино-Таланчанская и др.) и энсиматического типа (Джидинская, Озерная, Баянхонгорская и др.) Палеоазиатского океана произошло дальнейшее активное формирование континентальной коры в регионе. При этом в энсиматических дугах на океанической коре были выявлены гайоты, которые предшествовали образованию островодужных сооружений. Формирование этих структур фиксируется мантийными и корово-мантийными источниками магматических расплавов (положительные величины $\left.\varepsilon_{\mathrm{Nd}}(\mathrm{T})\right)$ и преимущественно эдиакарским возрастом протолитов в пределах каледонской изотопной провинции.
4. На позднекаледонском этапе (ордовик и силур) четко проявлены аккреционно-коллизионные процессы развития каледонид с внедрением коровых гранитоидов со смешанными источниками и, главным образом, неопротерозойским $\mathrm{Nd}$ модельным возрастом протолитов $\mathrm{T}_{\mathrm{Nd}}(\mathrm{DM})=1.50-0.99$ млрд лет. Это прослеживается в Джидинской, Хамар-Дабанской, Удино-Витимской и Озерной зонах развития каледонид Забайкалья и Монголии. Приведенные материалы подтверждают вывод о том, что каледонская континентальная кора в исследованном регионе образовалась в основном за счет аккреции островных дуг, окраинных бассейнов, фрагментов древних микроконтинентов с океаническими островами и плато Палеоазиатского океана. Докаледонская кора тоже участвовала в этом процессе в виде продукта эрозии основания Сибирского кратона либо микроконтинентов. В этих преобразованиях также предусматривается активная роль внутриплитного магматизма и мантийных плюмов при формировании континентальной коры.

5. Наиболее активно внутриплитные магматические процессы, связанные с мантийными плюмами, проявились на герцинском этапе (девон и пермокарбон) развития Монголо-Забайкальского региона. В результате многолетних исследований нами был выделен и частично изучен целый ряд фрагментов раннегерцинских островных дуг (Северо-Хангайская, СевероХэнтэйская, Северо-Агинская (Береинская), Уртуйская, Ольдойская, Адацагская, Норовлин-Ононская, ЮжноГобийская), океанических островов и плато (гайоты), связанных с развитием Монголо-Охотского океанического бассейна и его активных окраин. Кроме того, на исследованной территории выделена крупная позднегерцинская провинция внутриплитных (плюмовых) магматических пород верхнего девона - карбона - перми и раннего триаса. Этот период в Забайкалье связывается с формированием ареалов щелочных пород в рифтогенных зонах Селенгино-Витимского вулканоплутонического пояса и связанных с ним гранитоидов Ангаро-Витимского батолита, а на территории Монголии - Хангайского гранитоидного батолита и окружающих ареалов щелочного магматизма. Таким образом, на герцинском этапе на данной территории широко проявились внутриплитные магматические процессы, связанные в основном с мантийными плюмами, которые привели к формированию крупной позднепалеозойской магматической провинции за счет коры разного возраста.

6. Установлено, что источниками расплавов субдукционного, коллизионного и внутриплитного магматизма, происходившего на протяжении всей фанерозойской истории формирования континентальной коры Монголо-Забайкальского региона, выступали преимущественно породы океанической коры при добавке небольших объемов древнего корового компонента докембрийских блоков, терригенных осадочных пород окраинных бассейнов, вулканогенные породы островодужного и рифтогенного типа, массивов 
базит-гипербазитов и гранитоидов различной геодинамической природы.

7. В результате проведенных исследований в настоящее время в истории развития изученного МонголоЗабайкальского региона можно выделить три главных этапа формирования основной массы континентальной коры: 1) карельский (неоархей-палеопротерозойский) - около $30 \%$, 2) байкальский (мезонеопротерозойский) - 50 \% и 3) палеозойский (каледонско-герцинский), на который приходится более 20 \% объема коры. Такой эволюционный ряд указывает на преобладание в источниках магматических пород раннего этапа древнего корового материала. В последующие этапы был сформирован основной объем континентальной коры с широким участием смешанных корово-мантийных и ювенильных источников.

\section{7. БЛАГОДАРНОСТИ}

Автор глубоко признателен безвременно ушедшему выдающемуся ученому-геологу Н.Л. Добрецову, который, находясь в августе 2020 г. в экспедиции на Байкале, ознакомился с рукописью данной статьи, высказал свои предложения по успешному завершению работы. Особую благодарность автор выражает Е.В. Склярову и Д.П. Гладкочубу за рецензирование статьи и конструктивные замечания, которые были учтены и способствовали опубликованию данной работы.

\section{8. ЛИТЕРАТУРА / REFERENCES}

Abramovich G.Ya., Polyakov G.V., Khrenov P.M. et al. (Eds), 1990. Map of Magmatic Formations of the Southern Areas of East Siberia and the Northern Areas of the Mongolian People's Republic. Scale 1:1500000. USSR Ministry of Geology, Moscow (in Russian) [Карта магматических формаций юга Восточной Сибири и северной части Монгольской Народной Республики. Масштаб 1:1500000 / Ред. Г.Я. Абрамович, Г.В. Поляков, П.М. Хренов и др. М.: Мингео CCCP. 1990].

Al'mukhamedov A.I., Gordienko I.V., Kuzmin M.I., Tomurtogoo O., Tomurkhuu D., 1996. The Dzhida Zone: A Fragment of the Paleoasian Ocean. Geotectonics 30 (4), 279-294.

Amelin Yu.V., Neymark L.A., Rytsk E.Yu., Nemchin A.A., 1996. Enriched Nd-Sr-Pb Isotopic Signatures in the Dovyren Layered Intrusion (Eastern Siberia, Russia): Evidence for Source Contamination by Ancient Upper-Crustal Material. Chemical Geology 129 (1-2), 39-69. https://doi.org/10. 1016/0009-2541(95)00135-2.

Andreev G.V., Gordienko I.V., Kuznetsov A.N., Kravchenko A.I., 1972. Apatite-Bearing Diorites of the South-Western Transbaikal. Buryat Publishing House, Ulan-Ude, 200 p. (in Russian) [Андреев Г.В., Гордиенко И.В., Кузнецов А.Н., Кравченко А.И. Апатитоносные диориты Юго-Западного Забайкалья. Улан-Удэ: Бурятское книжное издательство, 1972. 200 с.].

Anisimova I.V., Levitsky I.V., Kotov A.B., Levitsky V.I., Reznitsky L.Z., Efimov S.V., Velikoslavinsky S.D., Barash I.G., Fedoseenko A.M., 2009. The Age of the Foundation of the Gargana Block (East Sayan): Results of U-Pb Geochronological Studies.
In: Isotope Systems and Timing of Geological Processes. Proceedings of the IV Russian Conference on Isotope Geochronology (June 02-04, 2009). Vol. 1. Institute of Precambrian Geology and Geochronology RAS, Saint Petersburg, p. 34-35 (in Russian) [Анисимова И.В., Левицкий И.В., Котов А.Б., Левицкий В.И., Резницкий Л.З., Ефимов С.В., Великославинский С.Д., Бараш И.Г., Федосеенко А.М. Возраст фундамента Гарганской глыбы (Восточный Саян): результаты U-Pb геохронологических исследований // Изотопные системы и время геологических процессов: Материалы IV Российской конференции по изотопной геохронологии (2-4 июня 2009 г.). СПб.: ИГГД РАН, 2009. T. 1. С. 34-35].

Ariskin A.A., Kostitsyn Yu.A., Konnikov E.G., Danyushevsky L.V., Meffre S., Nikolaev G.S., McNeill A., Kislov E.V., Orsoev D.A., 2013. Geochronology of the Dovyren Intrusive Complex, Northwestern Baikal Area, Russia, in the Neoproterozoic. Geochemistry International 51, 859-875. https:// doi.org/10.1134/S0016702913110025.

Avdeiko G.P., Popruzhenko S.V., Palueva A.A., 2001. Modern Structure of the Kurile-Kamchatka Region and Magma Forming Conditions. In: Geodynamics and Volcanism of the Kurile-Kamchatka Island-Arc System. Institute of Volcanic Geology and Geochemistry FEB RAS, Petropavlovsk-Kamchatsky, p. 9-33 (in Russian) [Авдейко Г.П., Попруженко С.В., Палуева А.А. Современная тектоническая структура Курило-Камчатского региона и условия магмообразования // Геодинамика и вулканизм Курило-Камчатской островодужной системы. Петропавловск-Камчатский: ИВГиГ ДВО РАН, 2001. С. 9-33].

Bogatikov O.A., Kovalenko V.I., Sharkov E.V., 2010. Magmatism, Tectonics, Geodynamics of Earth. Time and Space Relationship. Nauka, Moscow, 606 p. (in Russian) [Богатиков О.А., Коваленко В.И., Шарков Е.В. Магматизм, тектоника, геодинамика Земли. Связь во времени и пространстве. М.: Наука, 2010. 606 с.].

Bulgatov A.N., 1988. Geological-Geophysical Model of the Upper Crust of the North Transbaikalia. Russian Geology and Geophysics 9, 62-68 (in Russian) [Булгатов А.Н. Геологогеофизическая модель верхней части коры севера Забайкалья //Геология и геофизика. 1988. № 9. С. 62-68].

Bulgatov A.N., 2015. Geodynamics of the Baikal Mountainous Region in the Late Riphean and Vendian - Early Paleozoic. GEO, Novosibirsk, 191 p. (in Russian) [Булгатов A.H. Геодинамика Байкальской горной области в позднем рифее и венде - раннем палеозое. Новосибирск: ГЕО, 2015. 191 c.].

Bulgatov A.N., Gordienko I.V., 1999. Terrains of the Baikal Mountain Region and the Placement of Gold Deposits within Them. Geology of Ore Deposits 41 (3), 230-240 (in Russian) [Булгатов А.Н., Гордиенко И.В. Террейны Байкальской горной области и размещение в их пределах месторождений золота // Геология рудных месторождений. 1999. T. 41. № 3. С. 230-240].

Bulgatov A.N., Gordienko I.V., 2002. Geological and Geophysical Structure of the Upper Crust in the Baikal Region and Adjacent Territories. In: Tectonics and Geophysics of the Lithosphere. Vol. 1. GEOS, Moscow, p. 83-86 (in Russian) 
[Булгатов А.Н., Гордиенко И.В. Геолого-геофизическое строение верхней части коры Байкальского региона и сопредельных территорий // Тектоника и геофизика литосферы. М.: ГЕОС, 2002. Т. 1. С. 83-86].

Bulgatov A.N., Gordienko I.V., 2014. Fold Systems of the Sayan-Baikal Mountain Area. In: Yu.G. Leonov, O.V. Petrov, I.I. Pospelov (Eds), Tectonics of Nothern, Central and Eastern Asia. Explanatory Note to the Tectonic Map of Northern-Central-Eastern Asia and Adjacent Areas at Scale 1:2500000. VSEGEI Printing House, Saint Petersburg, p. 53-59.

Bulgatov A.N., Gordienko I.V., Zaitsev P.F., Turunkhaev V.I., 1997. Atlas of Geodynamic Maps and Deep Structure Maps of Transbaikalia. In: Tectonics of Asia. Proceedings of XXX Tectonic Conference. GEOS, Moscow, p. 39-41 (in Russian) [Булгатов А.Н., Гордиенко И.В., Зайцев П.Ф., Турунхаев В.И. Атлас геодинамических карт и карт глубинного строения Забайкалья // Тектоника Азии: Материалы XXX тектонического совещания. М.: ГЕОС, 1997. С. 39-41].

Bulgatov A.N., Gordienko I.V., Zaitsev P.F., Turunkhaev V.I., 2004. Geodynamic Map of the Baikal Region and Its Surrounding Territories. Scale 1:2000000. GIN SB RAS, Ulan-Ude (in Russian) [Булгатов А.Н., Гордиенко И.В., Зайцев П.Ф., Турунхаев В.И. Геодинамическая карта Байкальского региона и сопредельных территорий. Масштаб 1:2000000. Улан-Удэ: ГИН СО РАН, 2004].

Cawood P.A., Hawkesworth C.J., Dhuime B., 2013. The Continental Record and the Generation of Continental Crust. Geological Society of America Bulletin 125 (1-2), 14-32. https://doi.org/10.1130/B30722.1.

Condie K.C., 2011. Earth as an Evolving Planetary System. Second Edition. Elsevier Academic Press, Amsterdam, 574 p. https://doi.org/10.1016/C2010-0-65818-4.

Condie K. C., Kröner A., 2013. The Building Blocks of Continental Crust: Evidence for a Major Change in the Tectonic Setting of Continental Growth at the End of the Archean. Gondwana Research 23 (2), 394-402. https://doi.org/10. 1016/j.gr.2011.09.011.

DePaolo D.J., Linn A.M., Schubert G., 1991. The Continental Crustal Age Distribution: Methods of Determining Mantle Separation Ages from Sm-Nd Isotopic Data and Application to the Southwestern United States. Journal of Geophysical Research 96 (B2), 2017-2088. https://doi.org/ 10.1029/90JB02219.

Dewey J.F., Bird J.M., 1970. Plate Tectonics and Geosynclines. Tectonophysics 10 (5-6), 625-638. https://doi.org/ 10.1016/0040-1951(70)90050-8.

Dietz R.S., 1961. Continent and Ocean Basin Evolution by Spreading of the Sea Floor. Nature 190, 854-857. https:// doi.org/10.1038/190854a0.

Dobretsov N.L., 1981. Global Petrological Processes. Nedra, Moscow, 236 p. (in Russian) [Добрецов Н.Л. Глобальные петрологические процессы. М.: Недра, 1981. 236 с.].

Dobretsov N.L., 1983. Ophiolites and the Problem of the Baikal-Muya Ophiolite Belt. In: Magmatism and Metamorphism of Baikal-Amur Railway Region and Their Role in the Formation of Useful Minerals. Nauka, Novosibirsk, p. 1119 (in Russian) [Добрецов Н.Л. Офиолиты и проблемы Байкало-Муйского офиолитового пояса // Магматизм и метаморфизм зоны БАМ и их роль в формировании полезных ископаемых. Новосибирск: Наука, 1983. С. 11-19].

Dobretsov N.L., 2003. Evolution of Structures of the Urals, Kazakhstan, Tien Shan, and Altai-Sayan Region within the Ural-Mongolian Fold Belt (Paleoasian Ocean). Russian Geology and Geophysics 44 (1-2), 3-26.

Dobretsov N.L., 2008. Geological Implications of the Thermochemical Plume Model. Russian Geology and Geophysics 49 (7), 441-454. https://doi.org/10.1016/j.rgg.2008. 06.002 .

Dobretsov N.L., 2010. Distinctive Petrological, Geochemical, and Geodynamic Features of Subduction-Related Magmatism. Petrology 18, 84-106. https://doi.org/10.1134/ S0869591110010042.

Dobretsov N.L., 2011a. Early Paleozoic Tectonics and Geodynamics of Central Asia: Role of Mantle Plumes. Russian Geology and Geophysics 52 (12), 1539-1552. https:// doi.org/10.1016/j.rgg.2011.11.003.

Dobretsov N.L., 2011b. Fundamentals of Tectonics and Geodynamics. Textbook. Novosibirsk State University, Novosibirsk, 492 p. (in Russian) [Добрецов Н.Л. Основы тектоники и геодинамики: Учебное пособие. Новосибирск: НГУ, 2011. 492 с.].

Dobretsov N.L., 2020. Plate Tectonics vs. Plume Tectonics Interplay: Possible Models and Typical Cases. Russian Geology and Geophysics 61 (5-6), 502-526. https://doi.org/10. 15372/RGG2020102.

Dobretsov N.L., Belichenko V.G., Butov Yu.P., Boos R.G., Gordienko I.V., Zhmodik S.M., Ignatovich V.I., Konstantinova K.K. et al., 1989a. Geology and Ore Bearing of the East Sayan. Nauka, Novosibirsk, 127 p. (in Russian) [Добрецов Н.Л., Беличенко В.Г., Бутов Ю.П., Боос Р.Г., Гордиенко И.В., Жмодик С.М., Игнатович В.И., Константинова К.К. и др. Геология и рудоносность Восточного Саяна. Новосибирск: Наука, 1989. 127 с.].

Dobretsov N.L., Buslov M.M., Safonova I.Yu., Kokh D.A., 2004. Fragments of Oceanic Islands in the Kurai and Katun' Accretionary Wedges of Gorny Altai. Russian Geology and Geophysics 45 (12), 1381-1403.

Dobretsov N.L., Gabov N.F., Dobretsova L.V., Kozyreva N.V., 1989b. Eclogite-Like Rocks (Drusites) and Eclogites in the Precambrian Blocks of Pribaikalie. In: Eclogites and Glaucophane Schists in Folded Areas. Nauka, Novosibirsk, p. 7-34 (in Russian) [Добрецов Н.Л., Габов Н.Ф., Добрецова Л.В., Козырева Н.В. Эклогитоподобные породы (друзиты) и эклогиты в докембрийских блоках Прибайкалья // Эклогиты и глаукофановые сланцы в складчатых областях. Новосибирск: Наука, 1989. С. 7-34].

Dobretsov N.L., Kirdyashkin A.G., Kirdyashkin A.A., 2001. Deep Geodynamics. GE0, Novosibirsk, 409 p. (in Russian) [Добрецов Н.Л., Кирдяшкин А.Г., Кирдяшкин А.А. Глубинная геодинамика. Новосибирск: ГЕО, 2001. 409 с.].

Donskaya T.V., 2019. Early Proterozoic Granitoid Magmatism of the Siberian Craton. Brief PhD Thesis (Doctor of Geology and Mineralogy). IEC SB RAS, Irkutsk, 38 p. (in Russian) [Донская T.B. Раннепротерозойский гранитоидный магматизм Сибирского кратона: Автореф. дис. ... докт. геол.-мин. наук. Иркутск: ИЗК СО РАН, 2019. 38 с.]. 
Donskaya T.V., Gladkochub D.P., Sklyarov E.V., Kotov A.B., Larin A.M., Starikova A.E., Mazukabzov A.M., Tolmacheva E.V., Velikoslavinskii S.D., 2018. Genesis of the Paleoproterozoic Rare-Metal Granites of the Katugin Massif. Petrology 26 (1), 47-64. http://dx.doi.org/10.1134/S0869591118010022.

Donskaya T.V., Sklyarov E.V., Gladkochub D.P., Mazukabzov A.M., Sal'nikova E.B., Kovach V.P., Yakovleva S.Z., Berezhnaya N.G., 2000. The Cis-Baikal Collisional Metamorphic Belt. Doklady Earth Sciences 374 (7), 1075-1079 (in Russian) [Донская Т.В., Скляров Е.В., Гладкочуб Д.П., Мазукабзов А.М., Сальникова Е.Б., Ковач В.П., Яковлева С.З., Бережная Н.Г. Прибайкальский коллизионный метаморфический пояс // Доклады РАН. 2000. Т. 374. № 7. C. 1075-1079].

Doronina N.A., Antonov A.Yu., Minina O.R., 2016. Sequence of Geological Events in the Tsipikan Block of Western Transbaikalia Based on New Paleontological and Geochronological Data. In: Geodynamic Evolution of the Lithosphere of the Central Asian Mobile Belt (from Ocean to Continent). Proceedings of Scientific Meeting (October 11-14, 2016). Iss. 14. IEC SB RAS, Irkutsk, p. 85-87 (in Russian) [Доронина Н.A., Антонов А.Ю., Минина О.Р. Последовательность геологических событий в ципиканском блоке Западного Забайкалья на основе новых палеонтологических и геохронологических данных // Геодинамическая эволюция литосферы Центрально-Азиатского подвижного пояса (от океана к континенту): Материалы научного совещания по Программе фундаментальных исследований ОНЗ РАН (11-14 октября 2016 г.). Иркутск: ИЗК СО РАН, 2016. Вып. 14. С. 85-87].

Doronina N.A., Minina O.R., Patrakhina A.V., Paderin I.P., Rodionov N.V., Vakulenko O.V., 2009a. Paleozoic Dykes of the Bagdarino Trough and the U-Pb (SHRIMP II) Zircon Age of the Tocher Formation. In: Geodynamic Evolution of the Lithosphere of the Central Asian Mobile Belt (from Ocean to Continent). Proceedings of Scientific Meeting (October 11-14, 2009). Iss. 7. Vol. 1. IEC SB RAS, Irkutsk, p. 95-97 (in Russian) [Доронина Н.А., Минина О.Р., Патрахина А.В., Падерин И.П., Родионов Н.В., Вакуленко О.В. Палеозойские дайки Багдаринского прогиба и возраст точерской свиты (датирование цирконов методом SHRIMP-II) // Геодинамическая эволюция литосферы Центрально-Азиатского подвижного пояса (от океана к континенту): Материалы научного совещания по Программе фундаментальных исследований ОНЗ РАН (11-14 октября 2009 г.). Иркутск: ИЗК СО РАН, 2009. Вып. 7. Т. 1. С. 95-97].

Doronina N.A., Nekrasov G.E., Presnyakov S.L., 2013. U-Pb Age of Boninites from the Yambui Block of the Baikal-Vitim Fold System (First Data). In: Geodynamic Evolution of the Lithosphere of the Central Asian Mobile Belt (from Ocean to Continent). Proceedings of Scientific Meeting (October 1518, 2013). Iss. 11. IEC SB RAS, Irkutsk, p. 95-97 (in Russian) [Доронина Н.А., Некрасов Г.Е., Пресняков С.Л. U-Pb возраст бонинитов Ямбуйского блока Байкало-Витимской складчатой системы (первые данные) // Геодинамическая эволюция литосферы Центрально-Азиатского подвижного пояса (от океана к континенту): Материалы научного совещания по Программе фундаментальных исследований ОНЗ РАН (15-18 октября 2013 г.). Иркутск: ИЗК СО РАН, 2013. Вып. 11. С. 95-97].

Doronina N.A., Rytsk E.Yu., Paderin I.P., Bogomolov E.S., Lebedev P.B., Petrova O.A., Kataeva E.S., Vakulenko O.V., Posokhov V.F., Patrakhina A.V., 2009b. Riphean Age of the Tsipikan Sequence: The First U-Pb, Sm-Nd, and Rb-Sr Isotope Datings. In: Geodynamic Evolution of the Lithosphere of the Central Asian Mobile Belt (from Ocean to Continent). Proceedings of Scientific Meeting (October 11-14, 2009). Iss. 7. Vol. 1. IEC SB RAS, Irkutsk, p. 98-100 (in Russian) [Доронина Н.A., Рыцк Е.Ю., Падерин И.П., Богомолов Е.С., Лебедев П.Б., Петрова О.А., Катаева Е.С., Вакуленко О.В., Посохов В.Ф., Патрахина А.В. Рифейский возраст ципиканской толщи (первые данные U-Pb, Sm-Nd, Rb-Sr изотопного датирования) // Геодинамическая эволюция литосферы Центрально-Азиатского подвижного пояса (от океана к континенту): Материалы научного совещания по Программе фундаментальных исследований ОНЗ РАН (1114 октября 2009 г.). Иркутск: ИЗК СО РАН, 2009. Вып. 7. T. 1. C. 98-100].

Doroshkevich A.G., Ripp G.S., Izbrodin I.A., 2011. Alkaline Rocks of the Vitim Province (Western Transbaikalia): Stages, Conditions of Formation, Sources. In: Geodynamic Evolution of the Lithosphere of the Central Asian Mobile Belt (from Ocean to Continent). Proceedings of Scientific Meeting (October 18-21, 2011). Iss. 9. IEC SB RAS Irkutsk, p. 81-83 (in Russian) [Дорошкевич А.Г., Рипп Г.С., Избродин И.А. Щелочные породы Витимской провинции (Западное Забайкалье): этапы, условия формирования, источники вещества // Геодинамическая эволюция литосферы Центрально-Азиатского подвижного пояса (от океана к континенту): Материалы научного совещания по Программе фундаментальных исследований ОНЗ РАН (1821 октября 2011 г.). Иркутск: ИЗК СО РАН, 2011. Вып. 9. C. 81-83].

Dril S.I., Golubev V.N., 2003. Nd-Sr Systematics and Ree Geochemistry of Rocks from Accretionary Complexes, Eastern Transbaikal Part of the Mongol-Okhotsk Belt. Doklady Earth Science 389 (3), 375-379.

Elbaev A.L., Gordienko I.V., Bayanova T.B., Gorokhovsky D.V., Orsoev D.A., Badmatsyrenova R.A., Zarubina O.V., 2018. U-Pb Age and Geochemical Characteristics of Ultramafic-Mafic Rocks of the Dzhida Zone Ophiolite Association (Southwestern Transbaikalia). Doklady Earth Sciences 478, 208-210. https://doi.org/10.1134/S1028334X18020022.

Fedorova M.E., 1977. Geological Setting and Petrology of Granitoids of the Khangai Batholith. Nauka, Moscow, 150 p. (in Russian) [Федорова М.E. Геологическое положение и петрология гранитоидов Хангайского батолита. М.: Наука, 1977. 150 с.].

Fedorovsky V.S., Sklyarov E.V., Izokh A.E., Kotov A.B., Lavrenchuk A.V., Mazukabzov A.M., 2010. Strike-Slip Tectonics and Subalkaline Mafic Magmatism in the Early Paleozoic Collisional System of the Western Baikal Region. Russian Geology and Geophysics 51 (5), 534-547. http://dx.doi.org/ 10.1016/j.rgg.2010.04.009.

Gladkochub D.P., 2004. Evolution of the Southern Siberian Craton in the Precambrian - Early Paleozoic and Its Relation 
to Supercontinental Cycles. Brief PhD Thesis (Doctor of Geology and Mineralogy). Moscow, 35 p. (in Russian) [Гладкочуб Д.П. Эволюция южной части Сибирского кратона в докембрии - раннем палеозое и ее связь с суперконтинентальными циклами: Автореф. дис. ... докт. геол.мин. наук. М., 2004. 35 с.].

Gladkochub D.P., Donskaya T.V., Fedorovskii V.S., Mazukabzov A.M., Sklyarov E.V., Lavrenchuk A.V., Lepekhina E.N., 2014. Fragment of the Early Paleozoic ( $500 \mathrm{Ma}$ ) Island Arc in the Structure of the Olkhon Terrane, Central Asian Fold Belt. Doklady Earth Sciences 457, 905-909. https://doi.org/ 10.1134/S1028334X14080042.

Gladkochub D.P., Donskaya A.M., Mazukabzov A.M., Sal'nikova E.B., Sklyarov E.V., Yakovleva S.Z., 2005. The Age and Geodynamic Interpretation of the Kitoi Granitoid Complex (Southern Siberian Craton). Russian Geology and Geophysics 46 (11), 1121-1133.

Gladkochub D.P., Donskaya T.V., Reddy S.M., Poller U., Bayanova T.B., Mazukabzov A.M., Dril S., Todt W., Pisarevsky S., 2009. Paleoproterozoic to Eoarchean Crustal Growth in Southern Siberia a ND-Isotope Synthesis. In: S.M. Reddy, R. Mazumder, D.A.D. Evans, A.S. Collins (Eds), Palaeoproterozoic Supercontinents and Global Evolution. Geological Society of London Special Publications 323 (1), 127-143. http://doi.org/10.1144/SP323.6.

Gladkochub D.P., Donskaya T.V., Wingate M.T.D., Mazukabzov A.M., Pisarevsky S.A., Sklyarov E.V., Stanevich A.M., 2010. A One-Billion-Year Gap in the Precambrian History of the Southern Siberian Craton and the Problem of the Transproterozoic Supercontinent. American Journal of Science 310 (9), 812-825. http://dx.doi.org/10.2475/09.2010.03.

Gladkochub D.P., Sklyarov E.V., Men'shagin Yu.V., Mazukabzov A.M., 2001. Geochemistry of Ancient Ophiolites of the Sharyzhalgai Uplift. Geochemistry International 39 (10), 947-958.

Goldstein S.J., Jacobsen S.B., 1988. Nd and Sr Isotopic Systematic of Rivers Water Suspended Material: Implications for Crustal Evolution. Earth and Planetary Science Letters 87 (3), 249-265. https://doi.org/10.1016/0012-821X (88)90013-1.

Golonka J., Krobicki M., Pajak J., Van Giang N., Zuchiewicz W., 2006. Global Plate Tectonics and Paleogeography of Southeast Asia. AGH University of Science and Technology, Krakov, 128 p.

Goneger T.A., 2018. Age and Petrological-Geochemical Features of the Andreevsky Massif (Northwestern Part of the Vitim Plateau). In: Geodynamics and Metallogeny of Northern and Central Asia. Proceedings of the V All-Russian Conference (August 27-31, 2018). Buryatian State University, UlanUde, p. 116-118 (in Russian) [Гонегер T.A. Возраст и петролого-геохимическая характеристика Андреевского массива (северо-западная часть Витимского плоскогорья) // Геодинамика и минерагения Северной и Центральной Азии: Материалы V Всероссийской конференции (27-31 августа 2018 г.). Улан-Удэ: Изд-во БГУ, 2018. C. 116-118].

Gordienko I.V., 1969. Devonian Volcano-Plutonic Formation in the Southeastern Part of the East Sayan. Buryatian
Publishing House, Ulan-Ude, 116 p. (in Russian) [Гордиенко И.В. Девонская вулкано-плутоническая формация юго-восточной части Восточного Саяна. Улан-Удэ: Бурятское книжное издательство, 1969. 116 с.].

Gordienko I.V., 1981. Experience of Mapping Magmatic Formations of the Sayan-Baikal Mountain Area on the Basis of Their Compositions. In: Magmatic Formations and Problems of Their Origins, Ore Potentials and Mapping. Novosibirsk, p. 157-158 (In Russian) [Гордиенко И.В. Опыт составления карты магматических формаций Саяно-Байкальской горной области на основе их вещественного состава // Магматические формации складчатых областей Сибири, проблемы их происхождения, рудоносности и картирования. Новосибирск, 1981. С. 157-158].

Gordienko I.V., 1986. Paleovolcanological Resonstructions of Middle and Late Upper Paleozoic Transbaikalia. Doklady of the USSR Academy of Sciences 286 (5), 1191-1195 (in Russian) [Гордиенко И.В. Палеовулканологические реконструкции среднего и верхнего палеозоя Забайкалья. Доклады АН СССР. 1986. Т. 286. С. 1191-1195].

Gordienko I.V., 1987. Paleozoic Magmatism and Geodynamics of the Central Asian Folded Belt. Nauka, Moscow, 240 p. (in Russian) [Гордиенко И.В. Палеозойский магматизм и геодинамика Центрально-Азиатского складчатого пояса. М.: Наука, 1987. 240 с.].

Gordienko I.V., 2001. The Role of Hotspots and Mantle Plumes in the Geological Development of the Mongolia-Transbaikalia Region. In: Geological and Mineragenetic Correlation in the Adjacent Regions of Russia, China and Mongolia. Proceedings of the IV International Academic Conference (October 16-20, 2001). Chita Institute of Natural Resources SB RAS, Chita, p. 14-17 (in Russian) [Гордиенко И.В. Роль горячих точек и мантийных плюмов в геологическом развитии Монголо-Забайкальского региона // Геологическая и минерагеническая корреляция в сопредельных районах России, Китая и Монголии: Материалы IV Международного симпозиума (16-20 октября 2001 г.). Чита: ЧИПР СО РАН, 2001. С. 14-17].

Gordienko I.V., 2003. Indicator Igneous Formations of the Central Asian Fold Belt and Their Role in Geodynamic Reconstructions of the Paleoasian Ocean. Russian Geology and Geophysics 44 (12), 1294-1304.

Gordienko I.V., 2004. Volcanism in Various Geodynamic Settings of the Central Asian Orogenic Belt. Lithosphere (3), 4-16 (in Russian) [Гордиенко И.В. Вулканизм различных геодинамических обстановок Центрально-Азиатского складчатого пояса // Литосфера. 2004. № 3. С. 4-16].

Gordienko I.V., 2006. Geodynamic Evolution of Late Baikalides and Paleozoids in the Folded Periphery of the Siberian Craton. Russian Geology and Geophysics 47 (1), 51-67.

Gordienko I.V., 2008. The Earth Evolution History. Textbook. GEO, Novosibirsk, 293 p. (in Russian) [Гордиенко И.В. История развития Земли: Учебное пособие. Новосибирск: ГЕО, 2008. 293 с.].

Gordienko I.V., 2018. The Role of Subduction and Collisional Magmatism in the Formation of the Continental Crust of Transbaikalia (by Isotope-Geochronological Data). In: Geodynamics and Metallogeny of North and Central Asia. 
Proceedings of V All-Russian Conference (August 27-31, 2018). Buryat State University Publishing Department, UlanUde, p. 119-121 (in Russian) [Гордиенко И.В. Роль субдукционного и коллизионного магматизма в формировании континентальной коры Забайкалья (по изотопно-геохронологическим данным) // Геодинамика и минерагения Северной и Центральной Азии: Материалы V Всероссийской конференции (27-31 августа 2018 г.). Улан-Удэ: Изд-во БГУ, 2018. С. 119-121].

Gordienko I.V., 2019a. Relationship between SubductionRelated and Plume Magmatism at the Active Boundaries of Lithospheric Plates in the Interaction Zone of the Siberian Continent and Paleoasian Ocean in the Neoproterozoic and Paleozoic. Geodynamics \& Tectonophysics 10 (2), 405-457 (In Russian) [Гордиенко И.В. Связь субдукционного и плюмового магатизма на активных границах литосферных плит в зоне взаимодействия Сибирского континента и Палеоазиатского океана в неопротерозое и палеозое // Геодинамика и тектонофизика. 2019. Т. 10. № 2. С. 405457]. https://doi.org/10.5800/GT-2019-10-2-0420.

Gordienko I.V., 2019b. Cenozoic and Modern Convergent Boundaries of Lithospheric Plates of the Western Pacific Type and Their Paleo-Analogues in the Mongolia-Transbaikalia Region. In: Rifting, Orogenesis and Accompanying Processes. Proceedings of the IV All-Russian Symposium with Participation of Foreign Scientists, Dedicated to the $90^{\text {th }}$ Anniversary of Academician Nikolay Logatchev. IEC SB RAS, Irkutsk, p. 52-55 (in Russian) [Гордиенко И.В. Кайнозойские и современные конвергентные границы литосферных плит западно-тихоокеанского типа и их палеоаналоги в Монголо-Забайкальском регионе // Рифтогенез, орогенез и сопутствующие процессы: Материалы IV Всероссийского симпозиума с участием иностранных ученых, посвященного 90-летию со дня рождения академика Н.А. Логачева. Иркутск: ИЗК СО РАН, 2019. С. 52-55].

Gordienko I.V., Andreev G.V., Kuznetsov A.N., 1978. Magmatic Formations of Paleozoic Sayan-Baikal Mountain Area. Nauka, Moscow, 220 p. (in Russian) [Гордиенко И.В., Андреев Г.В., Кузнецов А.Н. Магматические формации палеозоя Саяно-Байкальской горной области. М.: Наука, 1978. 220 c.].

Gordienko I.V., Antonov A.Yu., Medvedev A.Ya., Orsoev D.A., Vetluzhskikh L.I., Badmatsyrenova R.A., Klimuk V.S., Elbaev A.L., Gorokhovsky D.V., 2012a. New Data on Magmatism and the Geological Structure of Central Transbaikalia. In: Geodynamic Evolution of the Lithosphere of the Central Asian Mobile Belt (from Ocean to Continent). Proceedings of Scientific Meeting (October 17-20, 2012). Iss. 10. Vol. 1. IEC SB RAS, Irkutsk, p. 60-62 (in Russian) [Гордиенко И.В., Антонов А.Ю., Медведев А.Я., Орсоев Д.А., Ветлужских Л.И., Бадмацыренова Р.А., Климук В.С., Елбаев А.Л., Гороховский Д.В. Новые данные по магматизму и геологическому строению Центрального Забайкалья // Геодинамическая эволюция литосферы Центрально-Азиатского подвижного пояса (от океана к континенту): Материалы научного совещания по Программе фундаментальных исследований ОНЗ РАН (17-20 октября 2012 г.). Иркутск: ИЗК СО РАН, 2012. Вып. 10. Т. 1. С. 60-62].
Gordienko I.V., Badmatsyrenova R.A., Lantseva V.S., Elbaev A.L., 2019a. Selenga Ore District in Western Transbaikalia: Structural and Mineragenetic Zoning, Genetic Types of Deposits and Geodynamic Settings of Ore Localization. Geology of Ore Deposits 61, 391-421. https://doi.org/10.1134/ S1075701519050027.

Gordienko I.V., Bulgatov A.N., Lastochkin N.I., Sitnikova V.S., 2009. Composition and U-Pb Isotopic Age Determinations (SHRIMP II) of the Ophiolitic Assemblage from the Shaman Paleospreading Zone and the Conditions of Its Formation (North Transbaikalia). Doklady Earth Sciences 429, 1420-1425. https://doi.org/10.1134/S1028334X09 090025.

Gordienko I.V., Bulgatov A.N., Ruzhentsev S.V., Minina O.R., Klimuk V.S., Vetluzhskikh L.I., Nekrasov G.E., Lastochkin N.I. et al., 2010. The Late Riphean-Paleozoic History of the Uda Vitim Island Arc System in the Transbaikalian Sector of the Paleoasian Ocean. Russian Geology and Geophysics 51 (5), 461-481. https://doi.org/10.1016/j.rgg.2010.04.005.

Gordienko I.V., Filimonov A.V., Minina O.R., 2004. Early and Late Paleozoic Collision Settings and Their Role in the Formation of Lithosphere in the Sayan-Baikal Folded Area. In: Evolution of Tectonic Processes in the Earth's History. Proceedings of the XXXVII Tectonic Meeting (February 1013, 2001). Vol. 1. GEO, Novosibirsk, p. 107-110 (in Russian) [Гордиенко И.В., Филимонов А.В., Минина О.Р. Ранне- и позднепалеозойские коллизионные обстановки и их роль в формировании литосферы Саяно-Байкальской складчатой области // Эволюция тектонических процессов в истории Земли: Материалы XXXVII тектонического совещания (10-13 февраля 2004 г.). Новосибирск: ГЕО, 2004. Т. 1. С. 107-110].

Gordienko I.V., Filimonov A.V., Minina O.R., Gornova M.A., Medvedev A.Ya., Klimuk V.S., Elbaev A.L., Tomurtogoo O., 2007. Dzhida Island-Arc System in the Paleoasian Ocean: Structure and Main Stages of Vendian-Paleozoic Geodynamic Evolution. Russian Geology and Geophysics 48(1), 91-106. https:// doi.org/10.1016/j.rgg.2006.12.009.

Gordienko I.V., Gorokhovsky D.V., Elbaev A.L., Bayanova T.B., 2015. New Data on the Early Paleozoic Gabbroid and Granitoid Magmatism Age within the Dzhida Zone of Caledonides (Southwestern Transbaikalia, North Mongolia). Doklady Earth Sciences 463, 817-821. https://doi.org/10. 1134/S1028334X15080103.

Gordienko I.V., Gorokhovsky D.V., Smirnova O.K., Lantseva V.S., Badmatsyrenova R.A., Orsoev D.A., 2018a. Dzhida Ore District: Geology, Structural and Metallogenic Regionalization, Genetic Types of Ore Deposits, Geodynamic Conditions of Their Formation, Forecast, and Outlook for Development. Geology of Ore Deposits 60,1-32. https://doi.org/10.1134/ S1075701518010038.

Gordienko I.V., Kiselev A.I., Lashkevich V.V., 2003a. Delamination of the Lithosphere and Its Associated Magmatism in Folded Belts (on the Example of Folded Framing in the Southern Areas of the Siberian Platform). In: D.V. Rundkvist (Ed.), Problems of Global Geodynamics. Proceedings of 1999-2001 Theoretical Seminars. Iss. 2. Department of Geology, Geophysics, Geochemistry and Mining Sciences RAS, Moscow, 
p. 185-200 (in Russian) [Гордиенко И.В., Киселев А.И., Лашкевич В.В. Деламинация литосферы и связанный с ней магматизм в складчатых поясах (на примере складчатого обрамления юга Сибирской платформы) // Проблемы глобальной геодинамики: Материалы теоретического семинара ОГГГГН РАН 1999-2001 гг. / Ред. Д.В. Рундквист. М.: ОГГГГН РАН, 2003. Вып. 2. С. 185-200].

Gordienko I.V., Kovach V.P., Elbaev A.L., Kotov A.B., Sal'nikova E.B., Reznitskii L.Z., Yakovleva S.Z., Anisimova I.V., 2012b. Collisional Granitoids of the Dzhida Zone of the Central Asian Fold Belt, Southwestern Transbaikalia: Age and Conditions of the Formation. Petrology 20, 40-58. https:// doi.org/10.1134/S086959111201002X.

Gordienko I.V., Kovach V.P., Gorokhovsky D.V., Saltykova E.B., Kotov A.B., Yakovleva S.Z., Zagornaya N.Yu., Fedoseenko A.M., Plotkina Yu.V., 2006. Composition, U-Pb Age, and Geodynamic Setting of Island-Arc Gabbroids and Granitoids of the Dzhida Zone (Southwestern Transbaikalia, Northern Mongolia). Russian Geology and Geophysics 47 (8), 948-955.

Gordienko I.V., Medvedev A.Ya., Badmatsyrenova R.A., 2012c. Geochemical and Geodynamic Features of the Paleozoic Basite and Ultra-Basite-Basite Complexes of the Western Khentey and Yablonovo-Malkhansky Regions (Northern Mongolia, Central Transbaikalia). In: Modern Problems of Geochemistry. Proceedings of All-Russia Scientific Meeting with International Participation, Dedicated to the 95th Anniversary of Academician L.V. Tauson (October 24-27, 2010). Vol. 2. Institute of Geochemistry SB RAS, Irkutsk, p. 44-47 (in Russian) [Гордиенко И.В., Медведев А.Я., Бадмацыренова P.A. Геохимические и геодинамические особенности палеозойских базитовых и ультрабазит-базитовых комплексов Западно-Хэнтэйского и Яблоново-Малханского регионов (Северная Монголия, Центральное Забайкалье) // Современные проблемы геохимии: Материалы Всероссийского совещания (с международным участием), посвященного 95-летию со дня рождения академика Л.В. Таусона (24-27 октября 2012 г.). Иркутск: ИГ СО РАН, 2012. Т. 2. С. 44-47].

Gordienko I.V., Medvedev A.Y., Gornova M.A., Tomurtogoo O., Goneger T.A., 2012d. The Haraa Gol Terrane in the Western Hentiyn Mountains (Northern Mongolia): Geochemistry, Geochronology, and Geodynamics. Russian Geology and Geophysics 53 (3), 281-292. https://doi.org/10.10 16/j.rgg.2012.02.005.

Gordienko I.V., Metelkin D.V., 2016. The Evolution of the Subduction Zone Magmatism on the Neoproterozoic and Early Paleozoic Active Margins of the Paleoasian Ocean. Russian Geology and Geophysics 57 (1), 69-81. https: / /doi.org/ 10.1016/j.rgg.2016.01.005.

Gordienko I.V., Metelkin D.V., Vetluzhskikh L.I., 2019b. The Structure of the Mongol-Okhotsk Fold Belt and the Problem of Recognition of the Amur Microcontinent. Russian Geology and Geophysics 60 (3), 267-286]. https://doi.org/ 10.15372/RGG2019018.

Gordienko I.V., Mikhal'tsov N.E., 2001. Position of Vendian - Early Cambrian Ophiolitic and Island-Arc Complexes of the Dzhida Zone of Caledonides in Paleoasian Oceanic
Structures: Interpretation of Paleomagnetic Data. Doklady Earth Sciences 379A (5), 622-626.

Gordienko I.V., Mikhal'tsov N.E., Filimonov A.V., 2003b. Composition and Structural Position of the Urminskaya Sequence of the Late Devonian in the Folded Frame of the Southern Areas of the Siberian Platform from Paleomagnetic Data. Doklady Earth Sciences 388 (5), 651-655 (in Russian) [Гордиенко И.В., Михальцов Н.Э., Филимонов А.В. Состав и структурное положение урминской толщи позднего девона в складчатом обрамлении юга Сибирской платформы по палеомагнитным данным // Доклады АН. 2003. T. 388. № 5. C. 651-655].

Gordienko I.V., Minina O.R., Vetluzhskikh L.I., Medvedev A.Ya., Odgerel D., 2018b. Hentei-Dauria Fold System of the Mongolia-Okhotsk Belt: Magmatism, Sedimentogenesis, and Geodynamics. Geodynamics \& Tectonophysics 9 (3), 1063-1097 (in Russian) [Гордиенко И.В., Минина О.Р., Ветлужских Л.И., Медведев А.Я., Одгэрэл Д. Хэнтей-Даурская складчатая система Монголо-Охотского пояса (магматизм, седиментогенез, геодинамика) // Геодинамика и тектонофизика. 2018. Т. 9. № 3. С. 1063-1097]. https:// doi.org/10.5800/GT-2018-9-3-0384.

Gordienko I.V., Roshchektaev P.A., Gorokhovsky D.V., 2016. Oka Ore District of the Eastern Sayan: Geology, Structural Metallogenic Zonation, Genetic Types of Ore Deposits, Their Geodynamic Formation Conditions, and Outlook for Development. Geology of Ore Deposits 58, 361-382. https://doi. org/10.1134/S1075701516050044.

Gordienko I.V., Tsygankov A.A., 2017. Magmatism and Ore Potential in Different Geodynamic Settings of the Sayan-Baikal Fold Belt and Its Adjacent Territories. Prospecting and Protection of Mineral Resources 9, 36-44 (in Russian) [Гордиенко И.В., Цыганков А.А. Магматизм и рудообразование в различных геодинамических обстановках Саяно-Байкальской складчатой области и сопредельных территорий // Разведка и охрана недр. 2017. № 9. С. 36-44].

Gradstein F.M., Ogg G.O., Smith A.G., Bleeker W., Lourens L.J., 2004. A New Geologic Time Scale, with Special Reference to Precambian and Neogene. Episodes 27 (2), 83-100.

Hegner E., Gordienko I.V., Iaccheri L.M., 2006. On the Origin of the Late Paleozoic Selenga-Vitim Magmatic Belt, Transbaikalia. In: Structural and Tectonic Correlation across the Central Asia Orogenic Collage: Implications for Continental Growth and Intracontinental Deformations. Abstracts of the Second International Workshop and Field Excursions for IGCP Project-480 (July 25 - August 5, 2005). Ulaanbaatar, Mongolia, p. 51-53.

Hofmann A.W., 1997. Mantle Geochemistry: The Message from Oceanic Volcanism. Nature 385, 219-229. https://doi. org/10.1038/385219a0.

Izokh A.E., Polyakov G.V., Gibsher A.S., Balykin P.A., Zhuravlev D.Z., Parkhomenko V.A., 1998. High-Alumina Layered Gabbroids of the Central-Asian Fold Belt: Geochemical Composition, Sm-Nd Isotopic Age, and Geodynamic Conditions of Formation. Russian Geology and Geophysics 39 (11), 1565-1577.

Khain E.V., Bibikova E.V., Kröner A., Zhuravlev D.Z., Sklyarov E.V., Fedotova A.A., Kravchenko-Berezhnoy I.R., 2002. The Most Ancient Ophiolite of the Central Asian Fold Belt: 
$\mathrm{U}-\mathrm{Pb}$ and $\mathrm{Pb}-\mathrm{Pb}$ Zircon Ages for the Dunzhugur Complex, Eastern Sayan, Siberia, and Geodynamic Implications. Earth and Planetary Science Letters 199 (3-4), 311-325. https:// doi.org/10.1016/s0012-821x(02)00587-3.

Khain V.E., Lomize M.G., 2005. Geotectonics with Fundamentals of Geodynamics. University Book House, Moscow, 500 p. (in Russian) [Хаин B.Е., Ломизе М.Г. Геотектоника с основами геодинамики. М.: Книжный дом «Университет», 2005. 500 с.].

Kheraskova T.N., Bush V.A., Didenko A.N., Samygin S.G., 2010. Breakup of Rodinia and Early Stages of Evolution of the Paleoasian Ocean. Geotectonics 44, 3-24. http://doi. org/10.1134/S0016852110010024.

Kheraskova T.N., Samygin S.G., Kurchavov A.M., Pospelov I.I., 2014. Structural Evolution and Geological History of the Tectonic Evolution of Ural-Mongolian Mobile Belt in the Neoproterozoic - Paleozoic (Kazakhstan and Tien Shan). In: Yu.G. Leonov, O.V. Petrov, I.I. Pospelov (Eds), Explanatory Note to the Tectonic Map of the Northern, Central and Eastern Asia and Adjacent Areas. Scale 1:2500000. VSEGEI Publishing House, Saint Petersburg, p. 169-182.

Konnikov E.G., 1986. Differentiated Hyperbasite-Basite Complexes of Transbaikalia Precambrian. Nauka, Novosibirsk, 217 p. (in Russian) [Конников Э.Г. Дифференцированные гипербазит-базитовые комплексы докембрия Забайкалья (петрология и рудообразование). Новосибирск: Наука, 1986. 217 с.].

Konnikov E.G., Tsygankov A.A., Vrublevskaya T.T., 1999. Baikal-Muya Volcano-Plutonic Belt: Structural-Material Complexes and Geodynamics. GEOS, Moscow, 163 p. (in Russian) [Конников Э.Г., Цыганков А.А., Врублевская Т.Т. Байкало-Муйский вулкано-плутонический пояс: структурно-вещественные комплексы и геодинамика. М.: ГЕОС, 1999. 163 с.].

Kovach V.P., Jian P., Yarmolyuk V.V., Kozakov I.K., Liu D., Terent'eva L.B., Lebedev V.I., Kovalenko V.I., 2005. Magmatism and Geodynamics of Early Stages of the Paleo-Asian Ocean Formation: Geochronological and Geochemical Data on Ophiolites of the Bayanhongor Zone. Doklady Earth Sciences 404 (7), 1072-1077.

Kovach V.P., Kotov A.B., Smelov A.P., Starosel'tsev K.V., Sal'nikova E.B., Zagornaya N.Yu., Safronov A.F., Pavlushin A.D., 2000. Evolutionary Stages of the Continental Crust in the Buried Basement of the Eastern Siberian Platform. Petrology 8 (4), 394-408 (in Russian) [Ковач В.П., Котов А.Б., Смелов А.П., Старосельцев К.В., Сальникова Е.Б., Загорная Н.Ю., Сафронов А.Ф., Павлушин А.Д. Этапы формирования континентальной коры погребенного фундамента восточной части Сибирской платформы // Петрология. 2000. Т. 8. № 4. С. 394-408].

Kovach V.P., Yarmolyuk V.V., Kovalenko V.I., Kozlovsky A.M., Kotov A.B., Terent'eva L.B., 2011. Composition, Sources, and Mechanisms of Formation of the Continental Crust of the Lake Zone of the Central Asian Caledonides. II. Geochemical and Nd Isotope Data. Petrology 19 (4), 399-425. https:// doi.org/10.1134/S0869591111030064.

Kovalenko V.I., Yarmolyuk V.V., Andreeva I.A., Ashikhmina N.A., Kozlovsky A.M., Kudryashova E.A., Kuznetsov V.A.,
Listratova E.N. et al., 2006. Magma Types and Their Sources in the Earth's History. Rare-Metal Magmatism: Rock Associations, Composition, and Magma Sources, Geodynamic Settings of Their Formation. In: O.A. Bogatikov, V.I. Kovalenko (Eds), Magma Types and Their Sources in the Earth's History. Part 2. Institute of Geology of Ore Deposits, Petrography, Mineralogy and Geochemistry (IGEM) RAS, Moscow, 280 p. (in Russian) [Коваленко В.И., Ярмолюк В.В., Андреева И.А., Ашихмина Н.А., Козловский А.М., Кудряшова Е.А., Кузнецов В.А., Листратова Е.Н. и др. Редкометалльный магматизм: ассоциации пород, состав источников магм, геодинамические обстановки формирования // Типы магм и их источники в истории Земли. Часть 2 / Ред. О.А. Богатиков, В.И. Коваленко. М.: ИГЕМ РАН, 2006. 280 с.].

Kovalenko V.I., Yarmolyuk V.V., Kovach V.P., Budnikov S.V., Zhuravlev D.Z., Kozakov I.K., Kotov A.B., Rytsk E.Yu., Sal'nikova E.B. 1999. Magmatism as Factor of Crust Evolution in the Central Asian Fold Belt: Sm-Nd Isotopic Data. Geotectonics 33 (3), 191-208.

Kovalenko V.I., Yarmolyuk V.V., Kovach V.P., Kotov A.B., Kozakov I.K., Sal'nikova E.B., 1996. Sources of Phanerozoic Granitoids in Central Asia: Sm-Nd Isotope Data. Geochemistry International 34 (8), 628-640.

Kovalenko V.I., Yarmolyuk V.V., Kovach V.P., Kotov A.B., Kozakov I.K., Sal'nikova E.B., 2003. Magmatism and Geodynamics of Early Caledonian Structures of the Central Asian Fold Belt (Isotope and Geological Data). Russian Geology and Geophysics 44 (12),1280-1293.

Kovalenko V.I., Yarmolyuk V.V., Kovach V.P., Kotov A.B., Kozakov I.K., Sal'nikova E.B., Larin A.M., 2004. Isotope Provinces, Mechanisms of Generation and Sources of the Continental Crust in the Central Asian Mobile Belt: Geological and Isotopic Evidence. Journal of Asian Earth Sciences 23 (5), 605-627. https://doi.org/10.1016/S1367-9120(03) 00130-5.

Kovalenko V.I., Yarmolyuk V.V., Tomurtogoo O., Antipin V.S., Kovach V.P., Kotov A.B., Kudryashova E.A., Sal'nikova E.B., Zagornaya N.Yu., 2005. Geodynamics and Crust-Forming Processes in the Early Caledonides of the Bayanhongor Zone, Central Mongolia. Geotectonics 39 (4), 298-316.

Kozakov I.K., Kovach V.P., Bibikova E.V., Kirnozova T.I., Lykhin D.A., Plotkina Yu.V., Tolmacheva E.V., Fugzan M.M., Erdenezhargal Ch., 2014. Late Riphean Episode in the Formation of Crystalline Rock Complexes in the Dzabkhan Microcontinent: Geological, Geochronologic, and Nd IsotopicGeochemical Data. Petrology 22, 480-506. https://doi.org/ 10.1134/S086959111405004X.

Kozakov I.K., Kovach V.P., Yarmolyuk V.V., Kotov A.B., Sal'nikova E.B., Zagornaya N.Yu., 2003. Crust-Forming Processes in the Geologic Development of the Tuva-Mongolia Massif: Sm-Nd Isotopic and Geochemical Data for Granitoids. Petrology 11 (5), 444-463.

Kozakov I.K., Sal'nikova E.B., Kovach V.P., Yarmolyuk V.V., Anisimova I.V., Kozlovsky A.M., Plotkina Yu.V., Myskova T.A. et al., 2008. Vendian Stage in Formation of the Early Caledonian Superterrane in Central Asia. Stratigraphy and Geological Correlation 16, 360. https://doi.org/10.1134/S086 9593808040023. 
Kozakov I.K., Sal'nikova E.B., Wang T., Didenko A.N., Plotkina Yu.V., Podkovyrov V.N., 2007. Early Precambrian Crystalline Complexes of the Central Asian Microcontinent: Age, Sources, Tectonic Position. Stratigraphy and Geological Correlation 15 (2), 121-140. https://doi.org/10.1134/S0869 593807020013.

Kozakov I.K., Salnikova E.B., Yarmolyuk V.V., Kovach V.P., Kozlovsky A.M., Anisimova I.V., Plotkina Yu.V., Fedoseenko A.M. et al., 2013. Crustal Growth Stages in the Songino Block of the Early Caledonian Superterrane in Central Asia: I. Geological and Geochronological Data. Petrology 21, 203220. https: //doi.org/10.1134/S0869591113020069.

Kozlovsky A.M., Yarmolyuk V.V., Kovalenko V.I., Savatenkov V.M., Velivetskaya T.A., 2007. Trachytes, Comendites, and Pantellerites of the Late Paleozoic Bimodal Rift Association of the Noen and Tost Ranges, Southern Mongolia: Differentiation and Contamination of Peralkaline Salic Melts. Petrology 15, 240-263. https://doi.org/10.1134/S08695 91107030034.

Kravchinsky V.A., Sorokin A.A., 2001. Paleomagnetism of Devonian Rocks in the Ol'doi Terrane, Upper Amur Region. Doklady Earth Sciences 377 (2), 147-151.

Kröner A., Kovach V.P., Alexeiev D.V., Wang K-L., Wong J., Degtyarev K.E., Kozakov I.K., 2017. No Excessive Crustal Growth in the Central Asian Orogenic Belt: Further Evidence from Field Relationships and Isotopic Data. Gondwana Research 50,135-166. https://doi.org/10.1016/j.gr.2017. 04.006.

Kröner A., Kovach V.P., Belousova E., Hegner E., Armstrong R., Dolgopolova A., Seltmann R., Alexeiev D.V. et al., 2014. Reassessment of Continental Growth during the Accretionary History of the Central Asian Orogenic Belt. Gondwana Research 25 (1), 103-125. https://doi.org/10.1016/j.gr. 2012.12.023.

Kungurtsev L.V., Berzin N.A., Kazansky A.Yu., Metelkin D.V., 2001. Tectonic Evolution of the Southwestern Framing of the Siberian Platform in the Vendian-Cambrian According to Paleomagnetic Data. Russian Geology and Geophysics 42 (7), 1042-1051 (in Russian) [Кунгурцев Л.В., Берзин Н.А., Казанский А.Ю., Метелкин Д.В. Тектоническая эволюция структуры юго-западного обрамления Сибирской платформы в венде - кембрии по палеомагнитным данным // Геология и геофизика. 2001. Т. 42. № 7. С. 1042-1051].

Kuzmichev A.B., Larionov A.N., 2013. Neoproterozoic Island Arcs in East Sayan: Duration of Magmatism (from $\mathrm{U}-\mathrm{Pb}$ Zircon Dating of Volcanic Clastics). Russian Geology and Geophysics 54 (1), 34-43. https://doi.org/10.1016/j. rgg.2012.12.003.

Kuzmin M.I., Yarmolyuk V.V., 2014. Mantle Plumes of Central Asia (Northeast Asia) and Their Role in Forming Endogenous Deposits. Russian Geology and Geophysics 55 (2), 120-143. https://doi.org/10.1016/j.rgg.2014.01.002.

Kuzmin M.I., Yarmolyuk V.V., 2016. Changes in the Manner of Tectonic Movements under the Earth's Evolution. Doklady Earth Sciences 469, 802-806. https://doi.org/10. 1134/S1028334X16080249.

Kuzmin M.I., Yarmolyuk V.V., Kotov A.B., Goryachev N.A., 2018. Magmatizm and Metallogeny of the Early Earth as a Reflection of Its Geologic Evolution. Russian Geology and Geophysics 59 (12), 1535-1547. https://doi.org/10.1016/ j.rgg.2018.12.001.

Kuzmin M.I., Yarmolyuk V.V., Kravchinsky V.A., 2010. Phanerozoic Hot Spot Traces and Paleogeographic Reconstructions of the Siberian Continent Based on Interaction with the African Large Low Shear Velocity Province. Earth-Science Reviews 102 (1-2), 29-59. https://doi.org/10.1016/j. earscirev.2010.06.004.

Kuznetsov Yu.A., 1964. Main Types of Magmatic Formations. Nedra, Moscow, 387 p. (in Russian) [Кузнецов Ю.А. Главные типы магматических формаций. М.: Недра, 1964. 387 c.].

Kuznetsov Yu.A., 1973. Current Status and Problems of the Magmatic Formation Studies. Russian Geology and Geophysics 8, 3-11 (in Russian) [Кузнецов Ю.А. О состоянии и задачах учения о магматических формациях. Геология и геофизика. 1973. Т. 8. С. 3-11].

Lantseva V.S., 2014. Volcanism of the Uda-Vitim Caledonides Zone of Western Transbaikalia (Composition, Age, Geodynamic Formation Settings). Brief PhD Thesis (Candidate of Geology and Mineralogy). Geological Institute SB RAS, Ulan-Ude, 19 p. (in Russian) [Ланцева В.С. Вулканизм Удино-Витимской зоны каледонид Западного Забайкалья (состав, возраст, геодинамические условия формирования): Автореф. дис. ... канд. геол.-мин. наук. УланУдэ: ГИН СО РАН, 2014. 19 с.].

Larin A.M., Kotov A.B., Sal'nikova E.B., Kovach V.P., Makar'ev L.B., Timashkov A.N., Berezhnaya N.G., Yakovleva S.Z., 2000. New Data on the Age of Granites of the Kodar and Tukuringra Complexes, Eastern Siberia: Geodynamic Constraints. Petrology 8 (3), 267-279 (in Russian) [Ларин A.M., Котов А.Б., Сальникова Е.Б., Ковач В.П., Макарьев Л.Б., Тимашков А.Н., Бережная Н.Г., Яковлева С.З. Новые данные о возрасте гранитов кодарского и тукурингрского комплексов, Восточная Сибирь: геодинамические следствия // Петрология. 2000. Т. 8. № 3. С. 267-279].

Lavrenchuk A.V., Sklyarov E.V., Izokh A.E., Kotov A.B., Sal'nikova E.B., Fedorovsky V.S., Mazukabzov A.M., 2017. Compositions of Gabbro Intrusions in the Krestovsky Zone (Western Baikal Region): A Record of Plume-Suprasubduction Mantle Interaction. Russian Geology and Geophysics 58 (10) 11391153. https://doi.org/10.1016/j.rgg.2017.09.001.

Le Pichon X., Francheteau J., Bonnin J., 1973. Plate Tectonics. Elsevier, New York, 300 p.

Li Z.X., Zhong S., 2009. Supercontinent - Superplume Coupling, True Polar Wander and Plume Mobility: Plate Dominance in Whole-Mantle Tectonics. Physics of the Earth and Planetary Interiors 176 (3-4), 143-156. https://doi. org/10.1016/j.pepi.2009.05.004.

Litvinovsky B.A., Zanvilevich A.N., Alakshin A.M., Podladchikov Yu.Yu., 1993. Angara-Vitim Batholith as the Largest Granitoid Pluton. United Institute of Geology, Geophysics and Mineralogy SB RAS, Novosibirsk, 141 p. (in Russian) [Литвиновский Б.А., Занвилевич А.Н., Алакшин А.М., Подладчиков Ю.Ю. Ангаро-Витимский батолит - крупнейший гранитоидный плутон. Новосибирск: ОИГГМ СО PAH, 1992. 141 c.]. 
Luchitsky I.V. (Ed.), 2001. Atlas of Paleovolcanological Maps of the North-Eastern Eurasia (Territory of Russia and Other CIS States). Scale 1:5000000. VSEGEI Publishing House, Saint Petersburg, 22 p. (in Russian) [Атлас палеовулканологических карт Северо-Восточной Евразии (территория России и других стран СНГ). Масштаб 1:5000000 / Ред. И.В. Лучицкий. СПб.: ВСЕГЕИ, 2001. 22 с.].

Makrygina V.A., Belichenko V.G., Reznitsky L.Z., 2007. Types of Paleoisland Arcs and Back-Arc Basins in the Northeast of the Paleoasian Ocean (from Geological Data). Russian Geology and Geophysics 48 (1), 107-119. https://doi. org/10.1016/j.rgg.2006.12.010.

Makrygina V.A., Belichenko V.G., Reznitsky L.Z., Sandimirov I.V., Sandimirova G.P., 2010. Ratio of Nd and Sr Isotopes and Model Ages of Metaterrigenous Rocks of the Zunmurin, Dzhida, and Khasurta Formations (Western Transbaikalia). In: Geodynamic Evolution of the Lithosphere of the Central Asian Mobile Belt (from Ocean to Continent). Proceedings of Scientific Meeting (October 14-17, 2010). Iss. 8. Vol. 2. IEC SB RAS, Irkutsk, p. 11-23 (in Russian) [Макрыгина B.A., Беличенко В.Г., Резницкий Л.З., Сандимиров И.В., Сандимирова Г.П., 2010. Соотношение изотопов $\mathrm{Nd}$ и $\mathrm{Sr}$ и модельных возрастов метатерригенных пород зунмуринской, джидинской и хасуртинской свит (Западное Забайкалье) // Геодинамическая эволюция литосферы Центрально-Азиатского подвижного пояса (от океана к континенту): Материалы научного совещания по Программе фундаментальных исследований ОНЗ РАН (14-17 октября 2010 г.). Иркутск: ИЗК СО РАН, 2010. Вып. 8. т. 2. С. 11-13].

Makrygina V.A., Petrova Z.I., Sandimirova G.P., Pakhol'chenko Y.A., 2005. New Data on the Age of the Strata Framing the Chuya and Cisbaikalian Uplifts (Northern and Western Baikal Areas). Russian Geology and Geophysics 46 (7), 697-706.

Maruyama S., Kumazawa M., Kawakami S., 1994. Towards a New Paradigm in the Earth's Dynamics. Journal of the Geological Society of Japan 100 (1), 1-3. https://doi.org/10.55 75/geosoc.100.1.

Maruyama S., Sawaki Y., Ebisuzaki T., Ikoma M., Omori S., Komabayashi T., 2014. Initiation of Leaking Earth: An Ultimate Trigger of the Cambrian Explosion. Gondwana Research 25 (3), 910-944. https://doi.org/10.1016/j.gr.2013.03.012.

Masaitis V.L. (Ed.), 1979. Magmatic Formations of the USSR. Vol. 1. 319 p. Vol. 2. 279 p. (in Russian) [Магматические формации СССР / Ред. В.Л. Масайтис. Л.: Недра, 1979. T. 1.319 с. T. 2.279 c.].

Mazukabzov A.M., Gladkochub D.P., Donskaya T.V., Stanevich A.M., Didenko A.N., Bibikova E.V., Vodovozov V.Yu., Kazansky A.A. et al., 2006. Precambian Evolution of the Southern Part of the Siberian Craton. SB RAS Publishing House, Novosibirsk, 367 p. (in Russian) [Мазукабзов A.M., Гладкочуб Д.П., Донская Т.В., Станевич А.М., Диденко А.Н., Бибикова Е.В., Водовозов В.Ю., Казанский А.А. и др. Эволюция южной части Сибирского кратона в докембрии. Новосибирск: Изд-во СО РАН, 2006. 367 с.].

Metelkin D.V., 2012. Evolution of Structures in Central Asia and the Role of Shear Tectonics from Paleomagnetic Data. IPGG SB RAS, Novosibirsk, 460 p. (in Russian) [Метелкин Д.В.
Эволюция структур Центральной Азии и роль сдвиговой тектоники по палеомагнитным данным. Новосибирск: ИНГГ СО РАН, 2012. 460 с.].

Metelkin D.V., 2013. Kinematic Reconstruction of the Early Caledonian Accretion in the Southwest of the Siberian Paleocontinent Based on Paleomagnetic Results. Russian Geology and Geophysics 54 (4), 381-398. https://doi.org/ 10.1016/j.rgg.2013.03.002.

Minina O.R., Doronina N.A., Nekrasov G.E., Vetluzhskikh L.I., Lantseva V.S., Aristov V.A., Naugol'hykh S.V., Kurilenko A.V., Khodyreva E.V., 2016. Early Hercynides of the Baikal-Vitim Fold System, Western Transbaikal Region. Geotectonics 50, 276-294. https://doi.org/10.1134/S0016852116030079.

Mongush A.A., Lebedev V.I., Kovach V.P., Sal'nikova E.B., Druzhkova E.K., Yakovleva S.Z., Plotkina Yu.V., Zagornaya N.Yu. et al., 2011. The Tectonomagmatic Evolution of StructureLithologic Complexes in the Tannu-Ola Zone, Tuva, in the Late Vendian - Early Cambrian (from Geochemical, Nd Isotope, and Geochronological Data). Russian Geology and Geophysics 52 (5), 503-516. https://doi.org/10.1016/j.rgg.2011.04.003.

Morgan W.J., 1972. Deep Mantle Convection Plumes and Plate Motions. American Association of Petroleum Geologists Bulletin 56 (2), 203-213. https://doi.org/10.1306/ 819A3E50-16C5-11D7-8645000102C1865D.

Nekrasov G.E., Rodionov N.V., Berezhnaya N.G., Sergeev S.A., Ruzhentsev S.V., Minina O.R., Golionko B.G., 2007. U-Pb Age of Zircons from Plagiogranite Veins in Migmatized Amphibolites of the Shaman Range (Ikat-Bagdarin Zone, Vitim Highland, Transbaikal Region). Doklady Earth Sciences 413, 160-163. https://doi.org/10.1134/S1028334X0702002X.

Orsoev D.A., Bulgatov A.N., Badmatsyrenova R.A., Gordienko I.V., 2012. Riphean Volcano-Plutonic Complex of the Burlin Local Spreading Zone (Western Transbaikalia): Age, Composition and Sources of Formation. In: Modern Problems of Magmatism and Metamorphism. Proceedings of the All-Russia Conference Dedicated to the 150th Anniversary of Academician F.Yu. Levinson-Lessing and the 100th Anniversary of Professor G.M. Saranchina (October 01-05, 2012). Vol. 2. Saint Petersburg University Press, Saint Petersburg, p. 106-108 (in Russian) [Орсоев Д.А., Булгатов А.Н., Бадмацыренова Р.А., Гордиенко И.В. Рифейский вулканоплутонический комплекс Бурлинской локальной спрединговой зоны (Западное Забайкалье): возраст, состав и источники формирования // Современные проблемы магматизма и метаморфизма: Материалы Всероссийской конференции, посвященной 150-летию академика Ф.Ю. Левинсона-Лессинга и 100-летию профессора Г.М. Саранчиной (01-05 октября 2012 г.). СПб.: Изд-во СПбГУ, 2012. Т. 2. С. 106-108].

Orsoev D.A., Mekhonoshin A.S., Gordienko I.V., Badmatsyrenova R.A., Kanakin S.V., Travin A.V., Volkova M.G., 2015. The Riphean Meteshikha Island-Arc Peridotite-Gabbro Massif (Western Transbaikalia). Russian Geology and Geophysics 56 (9), 1213-1231. https://doi.org/10.1016/j.rgg. 2015.08.001.

Orsoev D.A., Mekhonoshin A.S., Kanakin S.V., Badmatsyrenova R.A., Khromova E.A., 2018. Gabbro-Peridotite the Late Riphean Plutonic Complex (Northern Baikal Area, Russia). 
Russian Geology and Geophysics 59 (5), 589-605. https:// doi.org/10.1016/j.rgg.2018.04.002.

Parfenov L.M., Bulgatov A.N., Gordienko I.V., 1995. Terranes and Accretionary History of the Transbaikal Orogenic Belts. International Geology Review 37 (8), 736-751. https:// doi.org/10.1080/00206819509465425.

Pechersky D.M., Didenko A.N., 1995. Paleo-Asian Ocean. Petromagnetic and Paleomagnetic Information on Its Lithosphere. IPE RAS, Moscow, 297 p. (in Russian) [Печерский Д.M., Диденко А.Н. Палеоазиатский океан. Петромагнитная и палеомагнитная информация о его литосфере. М.: ОИФЗ PAH, 1995. 297 c.].

Peive A.V., 1969. Oceanic Crust of Geological Past. Geotectonics 4, 5-23 (in Russian) [Пейве А.В. Океаническая кора геологического прошлого // Геотектоника. 1969. № 4. C. 5-23].

Peive A.V., Yanshin A.L., Zonenshain L.P., Knipper A.L., Markov M.S., Mossakovsky A.A., Perfiliev A.S., Pushcharovsky Yu.M. et al., 1976. Formation of Continental Crust in Northern Eurasia (in Connection with Construction of a New Tectonic Map). Geotectonics 5, 6-23 (in Russian) [Пейве A.B., Яншин А.Л., Зоненшайн Л.П., Книппер А.Л., Марков М.С., Моссаковский А.А., Перфильев А.С., Пущаровский Ю.М. и др. Становление континентальной земной коры Северной Евразии (в связи с составлением новой тектонической карты) // Геотектоника. 1976. № 5. С. 6-23].

Petrov O.V., Leonov Yu.G., I.I. Pospelov (Eds), 2014. Tectonics of Nothern, Central and Eastern Asia. Explanatory Note to the Tectonic Map of Northern-Central-Eastern Asia and Adjacent Areas at Scale 1:2500 000. VSEGEI Printing House, Saint Petersburg, 192p.

Reznitsky L.Z., Makrygina V.A., Kovach V.P., Belichenko V.G., Kotov A.B., 2008. Lower Age Limit for Protoliths of the Khamardaban, Tunka, and Dzhida Terranes: Sm-Nd Data on Metaterrigenous Rocks. In: Geodynamic Evolution of the Lithosphere of the Central Asian Mobile Belt (from Ocean to Continent). Proceedings of Scientific Meeting (October 14-18, 2008). Iss. 6. Vol. 2. IEC SB RAS, Irkutsk, p. 62-64 (in Russian) [Резницкий Л.З., Макрыгина В.А., Ковач В.П., Беличенко В.Г., Котов А.Б. Нижний предел возраста протолитов Хамардабанского, Тункинского и Джидинского террейнов: Sm-Nd данные по метатерригенным породам // Геодинамическая эволюция литосферы ЦентральноАзиатского подвижного пояса (от океана к континенту): Материалы научного совещания по Программе фундаментальных исследований ОНЗ РАН (14-18 октября 2008 г.). Иркутск: ИЗК СО РАН, 2008. Вып. 6. Т. 2. C. 62-64].

Rudenko V.E., Stepanov D.V., Vinogradova V.P., Matukov D.I., Larionov A.N., 2010. New Data on the Geology and Geochronology of the Southwestern Margin of the AngaraVitim Area of Granitoids. In: Geology and Minerageny of Transbaikalia. Collection of Reports and Articles for the Research and Production Conference Dedicated to the 60th Anniversary of Chitageols'emka Federal State Unitary Geological Enterprise (October 22-23, 2010). Transbaikalia State University, Chita, 151-160 (in Russian) [Руденко B.Е., Степанов Д.В., Виноградова В.П., Матуков Д.И., Ларионов А.Н.
Новые данные по геологии и геохронологии юго-западной окраины Ангаро-Витимского ареала гранитоидов // Геология и минерагения Забайкалья. Сборник докладов и статей к научно-производственной конференции, посвященной 60-летию ФГУГП «Читагеолсъемка» (22-23 октября 2010 г.). Чита: ЗабГУ, 2010. С. 151-160].

Rudnev S.N., 2013. Early Paleozoic Granitoid Magmatism in the Altai-Sayan Folded Area and the Lake Zone in Western Mongolia. SB RAS Publishing House, Novosibirsk, 300 p. (in Russian) [Руднев C.Н. Раннепалеозойский гранитоидный магматизм Алтае-Саянской складчатой области и Озерной зоны Западной Монголии. Новосибирск: Изд-во СО РАН, 2013. 300 с.].

Ruppen D., Knaf A., Bussien D., Winkler W., Chimedtseren A., Quadt A., 2014. Restoring the Silurian to Carboniferous Northern Active Continental Margin of the MongolOkhotsk Ocean in Mongolia: Hangay-Hentey Accretionary Wedge and Seamount Collision. Gondwana Research 25 (4), 1517-1534. https://doi.org/10.1016/j.gr.2013.05.022.

Ruzhentsev S.V., Minina O.R., Nekrasov G.E., Aristov V.A., Golionko B.G., Doronina N.A., Lykhin D.A., 2012. The BaikalVitim Fold System: Structure and Geodynamic Evolution. Geotectonics 46, 87-110. https://doi.org/10.1134/S0016 852112020033.

Ruzhentsev S.V., Nekrasov G.E., 2009. Tectonics of the Aga Zone, Mongolia-Okhotsk Belt. Geotectonics 43, 34-50. https://doi.org/10.1134/S0016852109010038.

Rytsk E.Yu., Amelin Yu.V., Rizvanova N.G., Krimsky R.Sh., Mitrofanov G.L., Mitrofanova N.N., Perelyaev V.I., Shalaev V.S., 2001. Age of Rocks in the Baikal-Muya Foldbelt. Stratigraphy and Geological Correlation 9 (4), 315-326.

Rytsk E.Yu., Kovach V.P., Kovalenko V.I., Yarmolyuk V.V., 2007. Structure and evolution of the continental crust in the Baikal Fold Region. Geotectonics 41, 440-464. http://doi. org/10.1134/S0016852107060027.

Rytsk E.Yu., Kovach V.P., Yarmolyuk V.V., Kovalenko V.I., 2011. Isotopic Structure and Evolution of the Continental Crust in the East Transbaikalian Segment of the Central Asian Foldbelt. Geotectonics 45, 349-377. http://dx.doi.org/10. 1134/S0016852111050037.

Rytsk E.Yu., Sal'nikova E.B., Kovach V.P., Kotov A.B., Yarmolyuk V.V., Anisimova I.V., Yakovleva S.Z., Fedoseenko A.M. et al., 2013. Timing of Accretion of the Malkhan-Konda Terrane (Western Transbaikal Region) to the Siberian Paleocontinent: Results of U-Pb Geochronological Studies of the Granitoids of the Malkhan Complex. Doklady Earth Sciences 448, 1216. https://doi.org/10.1134/S1028334X13010200.

Rytsk E.Yu., Velikoslavinsky S.D., Bogomolov E.S., Kovach V.P., Alekseev I.A., Samorukov V.I., 2018. Geology of the Karalon Gold Ore Field in the Mid-Vitim Highlands. Geology of Ore Deposits 60, 300-327. https://doi.org/10.1134/S1 075701518040049.

Safonova I.Yu., Buslov M.M., Simonov V.A., Izokh A.E., Komiya Ts., Kurganskaya E.V., Ohno T., 2011. Geochemistry, Petrogenesis and Geodynamic Origin of Basalts from the Katun' Accretionary Complex of Gorny Altai (Southwestern Siberia). Russian Geology and Geophysics 52 (4), 421-442. https://doi.org/10.1016/j.rgg.2011.03.005. 
Shatsky V.S., Yagoutz E., Ryboshlykov Yu.V., Koz'menko O.A., Vavilov M.A., 1996. Eclogites of the Northern Muya Block: Evidence of the Vendian Collision in the Baikal-Muya Ophiolitic Belt. Doklady Earth Science 350 (5), 677-680 (in Russian) [Шацкий В.С., Ягоутц Э., Рыбошлыков Ю.В., Козьменко О.А., Вавилов М.А. Эклогиты Северо-Муйской глыбы: свидетельство вендской коллизии в Байкало-Муйском офиолитовом поясе // Доклады АН. 1996. T. 350. № 5. C. 677-680].

Simonov V.A., Gordienko I.V., Stupakov S.I., Medvedev A.Ya., Kotlyarov A.V., Kovyazin S.V., 2014. Conditions of Basalt Formation in the Dzhida Zone of the Paleoasian Ocean. Russian Geology and Geophysics 55 (8), 929-940. https://doi.org/ 10.1016/j.rgg.2014.07.001.

Sklyarov E.V., Dobretsov N.L., 1987. Metamorphism of Ancient Ophiolites of Eastern and Western Sayan. Russian Geology and Geophysics 2, 3-14 (in Russian) [Скляров E.В., Добрецов Н.Л. Метаморфизм древних офиолитов Восточного и Западного Саяна // Геология и геофизика. 1987. № 2. C. 3-14].

Sklyarov E.V., Fedorovsky V.S., Kotov A.B., Lavrenchuk A.V., Mazukabzov A.M., Levitsky V.I., Sal'nikova E.B., Starikova A.E. et al., 2009. Carbonatites in Collisional Settings and PseudoCarbonatites of the Early Paleozoic Ol'khon Collisional System. Russian Geology and Geophysics 50 (12), 1091-1106. https://doi.org/10.1016/j.rgg.2009.11.008.

Sklyarov E.V., Gladkochub D.P., Donskaya T.V., Kozakov I.K., 2002. Supercontinents in Precambrian Geological Development. Geotektonika 3, 95-96 (in Russian) [Скляров E.В., Гладкочуб Д.П., Донская Т.В., Козаков И.К. Суперконтиненты в геологическом развитии докембрия // Геотектоника. 2002. № 3. С. 95-96].

Sklyarov E.V., Gladkochub D.P., Mazukabzov A.M., Menshagin Yu.V., Konstantinov K.M., Watanabe T., 2000. Dike Swarms in the Southern Flank of the Siberian Craton as the Indicators of the Rodinia Supercontinent Breakup. Geotectonics 6, 59-75 (in Russian) [Скляров Е.В., Гладкочуб Д.П., Мазукабзов А.М., Меньшагин Ю.В., Константинов К.М., Ватанабе Т. Дайковые рои южного фланга Сибирского кратона - индикаторы распада суперконтинента Родиния // Геотектоника. 2000. № 6. C. 59-75].

Sklyarov E.V., Kovach V.P., Kotov A.B., Kuzmichev A.B., Lavrenchuk A.V., Perelyaev V.I., Shchipansky A.A., 2016. Boninites and Ophiolites: Problems of Their Relations and Petrogenesis of Boninites. Russian Geology and Geophysics 57 (1), 127-140. https://doi.org/10.1016/j.rgg.2016.01.009.

Sklyarov E.V., Mazukabzov A.M., Donskaya T.V., Doronina N.A., Shafeev A.A., 1994. Complex of the Metamorphic Core of the Zagan Ridge (Transbaikalia). Doklady Earth Science 339 (1), 83-86 (in Russian) [Скляров Е.В., Мазукабзов А.М., Донская Т.В., Доронина Н.А., Шафеев А.А. Комплекс метаморфического ядра Заганского хребта (Забайкалье) // Доклады АН. 1994. Т. 339. № 1. С. 83-86].

Sorokin A.A., Smirnova Yu.N., Kotov A.B., Kovach V.P., Sal'nikova E.B., Popeko L.I., 2015. Provenances of the Paleozoic Terrigenous Sequences of the Oldoi Terrane of the Central Asian Orogenic Belt: Sm-Nd Isotope Geochemistry and U-Pb Geochronology (LA-ICP-MS). Geochemistry International
53, 534-544. https://doi.org/10.1134/S00167029150 40072 .

Taylor S.R., McLennan S.M., 1985. The Continental Crust: Its Composition and Evolution. Blackwell, Oxford, 379 p.

Terent'eva L.B., Kozakov I.K., Yarmolyuk V.V., Anisimova I.V., Kovach V.P., Kozlovsky A.M., Kudryashova E.A., Sal'nikova E.B. et al., 2010. Convergent Processes in the Evolution of the Early Caledonian Bayan-Khongor Zone of Central Asia: Evidence from Geological and Geochronological Investigations of the Khan-Ula Gabbroid Pluton. Doklady Earth Sciences 433, 937-943. https: //doi.org/10.1134/S10283 34X10070202.

Tomurhuu D., Bolorjargal P., Jian Ping, 2007. New Dating and Geochemistry of Dzhida Boninite Series Rocks and Its Tectonic Constrain. In: Structural and Tectonic Correlation across the Central Asian Orogenic Collage: Implication for Continental Growth and Intracontinental Deformation. Proceedings of Third International Workshop and Field Excussion for IGCP-480. Beijing, China, p. 33.

Tomurtogoo O., 2014. Tectonics of Mongolia. In: O.V. Petrov, Yu.G. Leonov, I.I. Pospelov (Eds), Tectonics of Nothern, Central and Eastern Asia. Explanatory Note to the Tectonic Map of Northern-Central-Eastern Asia and Adjacent Areas at Scale 1:2500000. VSEGEI Printing House, Saint Petersburg, p. 110-126.

Tsydypov Zh.N., Mekhonoshin A.S., Kislov E.V., Orsoev D.A., Travin A.V., Kolotilina T.B., 2006. Geochemistry and Geochronology of Ultramafic-Mafic Rocks of the Urbikan Complex. In: Geodynamic Evolution of the Lithosphere of the Central Asian Mobile Belt (from Ocean to Continent). Proceedings of Scientific Meeting (October 16-20, 2006). Vol. 2. Iss. 4. IEC SB RAS, Irkutsk, p. 206-209 (in Russian) [Цыдыпов Ж.Н., Мехоношин А.С., Кислов Е.В., Орсоев Д.А., Травин А.В., Колотилина Т.Б. Геохимия и геохронология ультрамафит-мафитовых пород Урбиканского комплекса // Геодинамическая эволюция литосферы Центрально-Азиатского подвижного пояса (от океана к континенту): Материалы научного совещания по Программе фундаментальных исследований ОНЗ РАН (16-20 октября 2006 г.). Иркутск: ИЗК СО РАН, 2006. Т. 2. Вып. 4. С. 206-209].

Tsygankov A.A., 2005. The Late Precambrian Magmatic History of the Baikal-Muya Volcanoplutonic Belt. SB RAS Publishing House, Novosibirsk, 306 p. (in Russian) [Цыганков А.А. Магматическая эволюция Байкало-Муйского вулканоплутонического пояса в позднем докембрии. Новосибирск: Изд-во СО РАН, 2005. 306 с.].

Tsygankov A.A., Burmakina G.N., Khubanov V.B., Buyantuev M.D., 2017a. Geodynamics of Late Paleozoic Batholith Forming Processes in Western Transbaikalia. Petrology 25, 396-418. https://doi.org/10.1134/S0869591117030043.

Tsygankov A.A., Khubanov V.B., Burmakina G.N., Udoratina O.V., 2017b. Magma Sources of Late Paleozoic Granitoids of Western Transbaikalia (New Nd-Hf Isotope Data). In: Geodynamic Evolution of the Lithosphere of the Central Asian Mobile Belt (from Ocean to Continent). Proceedings of Scientific Meeting (October 17-20, 2017). Iss. 15. IEC SB RAS, Irkutsk, p. 290-292 (in Russian) [Цыганков A.A., Хубанов В.Б., Бурмакина Г.Н., Удоратина О.В. Источни- 
ки магм позднепалеозойских гранитоидов Западного Забайкалья (новые Nd-Hf изотопные данные) // Геодинамическая эволюция литосферы Центрально-Азиатского подвижного пояса (от океана к континенту): Материалы научного совещания по Программе фундаментальных исследований ОНЗ РАН (17-20 октября 2017 г.). Иркутск: ИЗК СО РАН, 2017. Вып. 15. С. 290-292].

Tsygankov A.A., Litvinovsky B.A., Jahn B.M., Reichow M.K., Liu D.Y., Larionov A.N., Presnyakov S.L., Lepekhina Ye.N., Sergeev S.A., 2010. Sequence of Magmatic Events in the Late Paleozoic of Transbaikalia, Russia (U-Pb Isotope Data). Russian Geology and Geophysics 51 (9), 972-994. https://doi. org/10.1016/j.rgg.2010.08.007.

Turutanov E.Kh., 2011. Angara-Vitim Batholith: Shape and Size According to Gravimetric Data. Doklady Earth Sciences 440 (6), 815-818 (in Russian) [Турутанов Е.Х. Ангаро-Витимский батолит: форма и размеры по гравиметрическим данным // Доклады АН. 2011. Т. 440. № 6. С. 815-818].

Vorontsov A.A., Yarmolyuk V.V., Fedoseev G.S., Perfilova O.Yu., Posokhov V.F., Travin A.V., Gazizova T.F., 2015. Differentiated Volcanic Association of the Minusa Trough: Mechanisms of Formation and Sources of Melts, as Exemplified by Bateneo Rise. Petrology 23, 353-375. https://doi.org/10. 1134/S0869591115040062.

Vrublevsky V.V., Izokh A.E., Polyakov G.V., Gertner I.F., Yudin D.S., Krupchatnikov V.I., 2009. Early Paleozoic Alkaline Magmatism of the Altai Mountains: ${ }^{40} \mathrm{Ar}-{ }^{39} \mathrm{Ar}$ Geochronology Data for the Edel'veis Complex. Doklady Earth Sciences 427, 846-850. https://doi.org/10.1134/S1028334X09050304.

Wilson J.T., 1963. A Possible Origin of the Hawaiian Islands. Canadian Journal of Physics 41 (6), 863-870. https: / doi.org/10.1139/p63-094.

Yanshin A.L. (Ed.), 1989. Map of Geological Formations of the Mongolian People's Republic. Scale 1:1500000. Proceedings of the Joint Soviet-Mongolian Geological Expedition. USSR Main Directorate of Geodesy and Cartography, Novosibirsk (in Russian) [Карта геологических формаций Монгольской Народной Республики. Масштаб 1:1500 000: Труды Совместной советско-монгольской геологической экспедиции / Ред. А.Л. Яншин. ГУГК СССР, Новосибирск, 1989].

Yarmolyuk V.V., Budnikov S.V., Kovalenko V.I., Antipin V.S., Goreglyad A.V., Sal'nikova E.B., Kotov A.B., Kozakov I.V. et al., 1997. Geochronology and Geodynamic Setting of the AngaraVitim Batholith. Petrology 5 (5), 401-414.

Yarmolyuk V.V., Degtyarev K.E., 2019. Precambrian Terrains of Central Asian Orogenic Belt: Comparative Characteristics, Types and Pecullirities of the Tectonic Evolution. Geotectonics 53 (1), 1-23. https://doi.org/10.1134/S001 6852119010096.

Yarmolyuk V.V., Kovach V.P., Kovalenko V.I., Sal'nikova E.B., Kozlovsky A.M., Kotov A.B., Yakovleva S.Z., Fedoseenko A.M., 2011. Composition, Sources, and Mechanism of Continental Crust Growth in the Lake Zone of the Central Asian Caledonides: I. Geological and Geochronological Data. Petrology 19 (1), 55-78. https://doi.org/10.1134/S0869591111010085.

Yarmolyuk V.V., Kovalenko V.I., 1982. Carboniferous Volcanism of Mongolia and the Geodynamic Setting of Its
Formation. Doklady of the USSR Academy of Sciences 263 (1), 172-174 (in Russian) [Ярмолюк В.В., Коваленко В.И. Каменноугольный вулканизм Монголии и геодинамическая обстановка его формирования // Доклады АН CCCP. 1982. T. 263. № 1. C. 172-174].

Yarmolyuk V.V., Kovalenko V.I., 1991. Riftogenic Magmatism of Active Continental Margins and Its Ore Potential. Nauka, Moscow, 263 p. (in Russian) [Ярмолюк В.В., Коваленко В.И. Рифтогенный магматизм активных континентальных окраин и его рудоносность. М.: Наука, 1991. 263 c.].

Yarmolyuk V.V., Kovalenko V.I., 2003. Deep Geodynamics and Mantle Plumes: Their Role in the Formation of the Central Asian Fold Belt. Petrology 11 (6), 504-531.

Yarmolyuk V.V., Kovalenko V.I., Kovach V.P., Budnikov S.V., Kozakov I.K., Kotov A.B., Salnikova E.B., 1999. Nd-Isotopic Systematics of Western Transbaikalian Crustal Protoliths: Implications for Riphean Crust Formation in Central Asia. Geotectonics 33 (4), 271-288.

Yarmolyuk V.V., Kovalenko V.I., Kovach V.P., Kozakov I.K., Kotov A.B., Sal'nikova E.B., 2002. Isotopic Composition, Sources of Crustal Magmatism, and Crustal Structure of Caledonides of the Ozernaya Zone, Central Asian Foldbelt. Doklady Earth Sciences 387 (9), 1043-1047.

Yarmolyuk V.V., Kovalenko V.I., Kovach V.P., Rytsk E.Yu., Kozakov I.k., Kotov A.B., Sal'nikova E.B., 2006. Early Stages of the Paleoasian Ocean Formation: Results of Geochronological, Isotopic, and Geochemical Investigations of Late Riphean and Vendian-Cambrian Complexes in the Central Asian Foldbelt. Doklady Earth Sciences 411, 1184-1189. https://doi.org/10.1134/S1028334X06080046.

Yarmolyuk V.V., Kovalenko V.I., Kozakov I.K., Sal'nikova E.B., Bibikova E.V., Kovach V.P., Kozlovsky A.M., Kotov A.B. et al., 2008. The Age of the Khangai Batholith and the Problem of Batholith Formation in Central Asia. Doklady Earth Sciences 423, 1223-1228. https: / /doi.org/10.1134/S102 $8334 X 08080096$.

Yarmolyuk V.V., Kozakov I.K., Kozlovsky A.M., Kudryashova E.A., Travin A.V., Kirnozova T.I., Fugzan M.M., Plotkina Yu.V., 2018. The Early Paleozoic Active Margin of the Khangai Segment of the Mongol-Okhotsk Ocean. Doklady Earth Sciences 480, 559-563. https://doi.org/10.1134/S1 $028334 X 18050094$.

Yarmolyuk V.V., Kozlovsky A.M., Lebedev V.I., 2017. Neoproterozoic Magmatic Complexes of the Songino Block (Mongolia): A Problem of Formation and Correlation of Precambrian Terranes in the Central-Asian Orogenic Belt. Petrology 25 (4), 365-395. https://doi.org/10.1134/S0869591117 040051.

Yarmolyuk V.V., Kozlovsky A.M., Salnikova E.B., Kozakov I.K., Kovach V.P., Kotov A.B., Tomurtogoo O., 2015. Structure, Age, and Geodynamic Settings of Early Neoproterozoic Magmatic Complexes of the Central Asian Fold Belt Exemplified by the Holbo Nur Zone of Songin Terrane. Doklady Earth Sciences 465, 1112-1116. https://doi.org/10.1134/ S1028334X15110082.

Yarmolyuk V.V., Kozlovsky A.M., Savatenkov V.M., Kovach V.P., Kozakov I.K., Kotov A.B., Lebedev V.I., Eenjin G., 
2016. Composition, Sources, and Geodynamic Nature of Giant Batholiths in Central Asia: Evidence from the Geochemistry and Nd Isotopic Characteristics of Granitoids in the Khangai Zonal Magmatic Area. Petrology 24 (5), 433461. https: //doi.org/10.1134/S0869591116050064.

Yarmolyuk V.V., Kuz'min M.I., Vorontsov A.A., 2013. West Pacific-Type Convergent Boundaries and Their Role in the Formation of the Central Asian Fold Belt. Russian Geology and Geophysics 54 (12), 1427-1441. https://doi.org/10.10 16/j.rgg.2013.10.012.

Yashina R.M., 1982. Alkaline Magmatism of Arched-Block Areas. Nauka, Moscow, 276 p. (in Russian) [Яшина P.M. Щелочной магматизм сводово-глыбовых областей. М.: Наука, 1982. 276 с.].

Zhao D., 2007. Seismic Images under 60 Hotspots: Search for Mantle Plumes. Gondwana Research 12 (4), 335-355. https://doi.org/10.1016/j.gr.2007.03.001.

Zonenshayn L.P., 1972. The Geosynclinal Theory and Its Application to the Central Asia Orogenic Belt. Nedra, Moscow,
240 p. (in Russian) [Зоненшайн Л.П. Учение о геосинклиналях и его приложение к Центрально-Азиатскому складчатому поясу. М.: Недра, 1972. 240 с.].

Zonenshayn L.P., Kuz'min M.I., 1983. Intraplate Volcanism and Its Significance in Understanding Processes in the Mantle. Geotectonics 17 (1), 18-31.

Zonenshayn L.P., Kuzmin M.I., 1993. Paleogeodynamics. Nauka, Moscow, 192 p. (in Russian) [Зоненшайн Л.Л., Кузьмин М.И. Палеогеодинамика. М.: Наука, 1993. 192 с.].

Zonenshayn L.P., Kuzmin M.I., Natapov L.M., 1990. Tectonics of Lithospheric Plates of the USSR. Book 1. Nedra, Moscow, 328 p. (in Russian) [Зонненшайн Л.П., Кузьмин М.И., Натапов Л.М. Тектоника литосферных плит территории СССР. Кн.1. М.: Недра, 1990. 328 с.].

Zorin Yu.A., Sklyarov E.V., Belichenko V.G., Mazukabzov A.M., 2009. Island Arc-Back-Arc Basin Evolution: Implications for Late Riphean - Early Paleozoic Geodynamic History of the Sayan-Baikal Folded Area. Russian Geology and Geophysics 50 (3), 149-161. https://doi.org/10.1016/j.rgg.2008.06.022.

\section{ПРИЛОЖЕНИЕ 1 / APPENDIX 1}

Таблица 1. Результаты Sm-Nd изотопных исследований магматических и осадочных пород Монголо-Забайкальского региона Table 1. The Sm-Nd isotope data on the magmatic and sedimentary rocks of the Mongolia-Transbaikalia region

\begin{tabular}{|c|c|c|c|c|c|c|c|}
\hline \multicolumn{8}{|c|}{ А. Результаты Sm-Nd изотопных исследований магматических пород } \\
\hline $\begin{array}{l}\text { Порода } \\
\text { (свита, толща, комплекс, массив) }\end{array}$ & $\begin{array}{l}\text { Возраст, } \\
\text { млн лет }\end{array}$ & \multicolumn{2}{|c|}{${ }^{147} \mathrm{Sm} /{ }^{144} \mathrm{Nd}{ }^{143} \mathrm{Nd} /{ }^{144} \mathrm{Nd}$} & $\varepsilon_{\mathrm{Nd}}(\mathrm{T})$ & $\begin{array}{l}\mathrm{T}_{\mathrm{ND}}(\mathrm{DM}) \\
\text { МЛН лет }\end{array}$ & $\begin{array}{l}\mathrm{T}_{\mathrm{ND}}(\mathrm{DM}-\mathrm{st}) \\
\text { мЛн лет }\end{array}$ & Источники \\
\hline \multicolumn{8}{|c|}{$\begin{array}{c}\text { Байкалиды } \\
\text { Мезо - неопротерозой }(1.6-0.60 \text { млрд }\end{array}$} \\
\hline \multicolumn{8}{|c|}{ Восточный Саян, Забайкалье } \\
\hline \multicolumn{8}{|c|}{$\begin{array}{c}\text { Нюрундуканская островная дуга } \\
\text { Островодужный и внутриплитный магматизм }\end{array}$} \\
\hline $\begin{array}{l}\text { Метатолеиты, метагаббро } \\
\text { (нюрундуканская) }\end{array}$ & $1035-850$ & & & $+5.6 \ldots+7.9$ & 2320-2000 & 2300 & [Rytsk et al., 2001] \\
\hline Метабазальт (тыйская) & $915 \pm 5$ & 0.1374 & 0.51110 & -7.0 & 2431 & & [Orsoev et al., 2018] \\
\hline Метабазальт (тыйская) & $915 \pm 5$ & 0.1369 & 0.51099 & -9.2 & 2642 & & * \\
\hline Метабазальт (тыйская) & $850-900$ & 0.209757 & 0.513063 & -14.4 & 3460 & 2870 & [Rytsk et al., 2001] \\
\hline Плагиориолит (иньяптукская) & 830 & 0.139459 & 0.511784 & -10.61 & 2794 & 2388 & $*$ \\
\hline Габбро-троктолит (довыренский) & $728-733$ & & & -15.8 & 2800 & 2700 & [Orsoev et al., 2018] \\
\hline * & $673-707$ & & & $-16.3,-14.1$ & & & [Amelin et al., 1996] \\
\hline Базальты-риолиты (сыннырская) & 729 & 0.1208 & 0.511573 & -13.7 & & & [Ariskin et al., 2013] \\
\hline Андезибазальт (олокитская) & 711 & 0.1339 & 0.511642 & -13.6 & & & $*$ \\
\hline Риолит (иньяптукская) & 730 & 0.1193 & 0.511863 & -8.0 & 2074 & 1953 & [Rytsk et al., 2001] \\
\hline \multicolumn{8}{|c|}{$\begin{array}{l}\text { Дунжугурская островная дуга } \\
\text { Островодужный магматизм }\end{array}$} \\
\hline Бонинит (дунжугурская) & $1010-1020$ & 0.0917 & 0.511885 & $-1.0 \ldots+1.5$ & $1800-1600$ & & [Sklyarov et al., 2016] \\
\hline \multicolumn{8}{|c|}{$\begin{array}{l}\text { Келянская островная дуга } \\
\text { Островодужный магматизм }\end{array}$} \\
\hline Толеиты - пикриты (асынская) & 953 & 0.13040 & 0.512236 & +0.2 & 1672 & 1592 & [Doronina et al., 2013] \\
\hline Риолиты (усть-келянская) & $789 \pm 8.5$ & 0.1366 & 0.512528 & +4.4 & 1232 & 1134 & $*$ \\
\hline Метадолерит (ципиканская) & 767 & 0.1833 & 0.512815 & +3.9 & 1686 & 735 & [Doronina et al., 2016] \\
\hline Риолит (горбылокская) & 825 & 0.1176 & 0.511640 & -11.1 & 2388 & 2274 & [Rytsk et al., 2001] \\
\hline Плагиогранит (муйский) & 815 & 0.1004 & 0.511698 & -8.3 & 1950 & 2055 & $*$ \\
\hline \multicolumn{8}{|c|}{ Коллизионный магматизм } \\
\hline Габбро-диорит (бамбукойский) & 788 & 0.15992 & 0.51243 & -0.3 & 1900 & 1700 & [Bulgatov, 2015] \\
\hline$*$ & 790 & 0.159918 & 0.512430 & -0.4 & 2041 & 1508 & $*$ \\
\hline
\end{tabular}


Таблица 1. (продолжение)

Table 1. (continued)

\begin{tabular}{|c|c|c|c|c|c|c|c|}
\hline $\begin{array}{l}\text { Порода } \\
\text { (свита, толща, комплекс, массив) }\end{array}$ & $\begin{array}{l}\text { Возраст, } \\
\text { млн лет }\end{array}$ & ${ }^{147} \mathrm{Sm} /{ }^{144} \mathrm{Nd}$ & ${ }^{143} \mathrm{Nd} /{ }^{144} \mathrm{Nd}$ & $\varepsilon_{\mathrm{Nd}}(\mathrm{T})$ & $\begin{array}{l}\mathrm{T}_{\mathrm{ND}}(\mathrm{DM}) \\
\text { млн лет }\end{array}$ & $\begin{array}{l}\mathrm{T}_{\mathrm{ND}}(\mathrm{DM}-\mathrm{st}), \\
\text { млн лет }\end{array}$ & Источники \\
\hline \multicolumn{8}{|c|}{ Внутриплитный магматизм } \\
\hline Габброиды (талалинский) & $615-603$ & & & +6.7 & & & [Ruzhentsev et al., 2012] \\
\hline Базальты-риолиты (каралонская) & 615 & 0.1326 & 0.512682 & +6.4 & 883 & 837 & [Rytsk et al., 2007] \\
\hline \multicolumn{8}{|c|}{$\begin{array}{c}\text { Метешихинская островная дуга } \\
\text { Островодужный магматизм }\end{array}$} \\
\hline Базальты-долериты (итанцинская) & 839 & & 0.512861 & +5.3 & 1211 & 1149 & [Gordienko, 2019a] \\
\hline Габбро (метешихинский) & 809 & 0.1693 & 0.512525 & +0.6 & 2146 & 1443 & [Orsoev et al., 2015] \\
\hline \multicolumn{8}{|c|}{$\begin{array}{c}\text { Катаевская островная дуга } \\
\text { Островодужный магматизм }\end{array}$} \\
\hline Андезибазальт (катаевская) & 893 & 0.1111 & 0.512639 & +9.3 & 762 & 754 & Author's \\
\hline Гранит (оборский) & 850 & 0.136210 & 0.512689 & +1.0 & 910 & 753 & * \\
\hline \multicolumn{8}{|c|}{ Коллизионный магматизм } \\
\hline Гнейсогранит (ишагинский) & $808-780$ & 0.1023 & 0.512191 & -8.7 & 1313 & 1413 & [Gordienko et al., 2019b] \\
\hline Гранит (урюмканский) & 778 & 0.0928 & 0.512297 & +3.7 & 1077 & 1163 & $*$ \\
\hline \multicolumn{8}{|c|}{ Монголия } \\
\hline
\end{tabular}

Островодужный и внутриплитный магматизм

\begin{tabular}{|c|c|c|c|c|c|c|c|}
\hline \\
\hline Риолит (холбонурский) & 880 & 0.1188 & 0.512506 & +6.5 & 1035 & 1038 & [Yarmolyuk et al., 2017] \\
\hline Кв. диорит (гашунурский) & 859 & 0.1156 & 0.512264 & +1.6 & 1977 & 1402 & $*$ \\
\hline Гнейсогранит (дзабханский) & 856 & 0.1388 & 0.512473 & +3.1 & 1379 & 1274 & [Kozakov et al., 2014] \\
\hline \multicolumn{8}{|c|}{ Тувино-Монгольский блок } \\
\hline Гнейсогранит (моренский) & 536 & 0.1546 & 0.512185 & -6.0 & 2484 & 1766 & [Kozakov et al., 2003] \\
\hline Гранит (эрзинский) & 495 & 0.1347 & 0.512365 & -1.4 & 1516 & 1356 & $*$ \\
\hline Кв. диорит (таннуольский) & 451 & 0.1235 & 0.512590 & +3.3 & 919 & 930 & $*$ \\
\hline Гранит (бреньский) & 450 & 0.1043 & 0.512389 & +0.5 & 1062 & 1165 & $*$ \\
\hline \multicolumn{8}{|c|}{$\begin{array}{c}\text { Каледониды } \\
\text { Эдиакарий - нижний палеозой (0.60-0.42 млрд лет) }\end{array}$} \\
\hline \multicolumn{8}{|c|}{ Забайкалье } \\
\hline \multicolumn{8}{|c|}{$\begin{array}{c}\text { Ангино-Таланчанская островная дуга } \\
\text { Островодужный и внутриплитный магматизм }\end{array}$} \\
\hline Габбро (бирхинский) & 499 & & & +2.9 & $819-930$ & & [Lavrenchuk et al., 2017] \\
\hline Лейкогранит (светлинский) & 550 & 0.0983 & 0.512561 & +5.4 & 780 & 806 & [Rytsk et al., 2007] \\
\hline Габбро-диориты (бирамьинский) & $468 \pm 8.4$ & & & $+4.7 \ldots+5.7$ & $820-980$ & $850-760$ & $*$ \\
\hline \multicolumn{8}{|c|}{$\begin{array}{c}\text { Удино-Витимская островная дуга } \\
\text { Островодужный магматизм }\end{array}$} \\
\hline Риолит (олдындинская) & $529 \pm 3.6$ & & & $-8.7 \ldots-1.3$ & 2000 & 1400 & [Ruzhentsev et al., 2012] \\
\hline \multicolumn{8}{|c|}{ Коллизионный магматизм } \\
\hline Гранодиорит (Киркоротский) & 472 & 0.1373 & 0.512387 & -1.3 & 1523 & 1330 & Author's \\
\hline Гранит (Югальский) & 460 & 0.07914 & 0.512413 & +2.5 & 837 & 1001 & $*$ \\
\hline Гнейсогранит ( Малханский) & 450 & 0.10623 & 0.512466 & +1.9 & 972 & 1049 & $*$ \\
\hline Гранит (Олнинский) & 430 & 0.097955 & 0.512415 & +1.1 & 970 & 1097 & [Doronina et al., 2016] \\
\hline \multicolumn{8}{|c|}{ Внутриплитный магматизм } \\
\hline Троктолит (ингодинский) & 440 & 0.17635 & 0.512963 & +7.5 & 769 & 571 & Author's \\
\hline$*$ & 440 & 0.111055 & 0.512813 & +8.2 & 503 & 509 & $*$ \\
\hline Габбро (малангинский) & 430 & 0.127343 & 0.512446 & +0.1 & 1245 & 1148 & * \\
\hline \multicolumn{8}{|c|}{$\begin{array}{c}\text { Джидинская островная дуга } \\
\text { Островодужный магматизм }\end{array}$} \\
\hline $\begin{array}{l}\text { Габбро-пироксениты } \\
\text { (бугуриктайский) офиолиты }\end{array}$ & 560 & 0.267105 & 0.513075 & +3.5 & 640 & & [Elbaev et al., 2018] \\
\hline
\end{tabular}


Таблица 1. (продолжение)

Table 1. (continued)

\begin{tabular}{|c|c|c|c|c|c|c|c|}
\hline $\begin{array}{l}\text { Порода } \\
\text { (свита, толща, комплекс, массив) }\end{array}$ & $\begin{array}{l}\text { Возраст, } \\
\text { млн лет }\end{array}$ & ${ }^{147} \mathrm{Sm} /{ }^{144} \mathrm{Nd}$ & ${ }^{143} \mathrm{Nd} /{ }^{144} \mathrm{Nd}$ & $\varepsilon_{\mathrm{Nd}}(\mathrm{T})$ & $\begin{array}{l}\mathrm{T}_{\mathrm{ND}}(\mathrm{DM}) \\
\text { МЛН лет }\end{array}$ & $\begin{array}{l}\mathrm{T}_{\mathrm{ND}}(\mathrm{DM}-\mathrm{st}), \\
\text { млн лет }\end{array}$ & Источники \\
\hline Габбро (холтосонский) & 506 & 0.1476 & 0.512802 & +6.4 & 805 & 740 & [Gordienko, 2018] \\
\hline Кв. диорит (модонкульский) & 504 & 0.1392 & 0.512791 & +6.7 & 737 & - & $*$ \\
\hline * & 504 & 0.155518 & 0.512854 & +6.9 & 780 & 675 & * \\
\hline Тоналит (джидинский) & 560 & 0.138855 & 0.512861 & +8.5 & 592 & 586 & $*$ \\
\hline \multicolumn{8}{|c|}{ Коллизионный магматизм } \\
\hline Тоналит (барунгольский) & $477 \pm 7$ & 0.1152 & 0.512397 & +0.3 & 1166 & 1201 & [Gordienko et al., 2012b] \\
\hline Тоналит (дархинтуйский) & $490 \pm 1$ & 0.0922 & 0.512362 & +1.2 & 990 & 1138 & * \\
\hline * & $489 \pm 2$ & 0.1035 & 0.512312 & -0.5 & 1160 & 1277 & $*$ \\
\hline Монцодиорит (хулдатский) & $490 \pm 2$ & 0.1250 & 0.512296 & -2.2 & 1466 & 1415 & $*$ \\
\hline \multicolumn{8}{|c|}{ Внутриплитный магматизм } \\
\hline Базальты (гайот джидотский) & 560 & & & $+6.9 \ldots+9.2$ & & & [Gordienko et al., 2012b] \\
\hline Габбро-норит (джидинский) & 560 & & & +6.0 & 721 & 682 & $*$ \\
\hline Габбро (шильдырхейский) & 495 & 0.2035 & 0.512852 & +3.8 & 1446 & 929 & [Gordienko, 2018] \\
\hline Габбро (хоштогольский) & 508 & 0.1994 & 0.512658 & +0.2 & 1521 & 1232 & * \\
\hline \multicolumn{8}{|c|}{ Таннуольско-Хамсанринская островная дуга } \\
\hline Базальт офиолитовый & 570 & 0.1800 & 0.513088 & +8.4 & & & [Mongush et al., 2011] \\
\hline Тоналит адакитовый & 570 & 0.1374 & 0.51277 & +7.0 & & & * \\
\hline Базальт отроводужный & 540 & 0.1656 & 0.512874 & +6.8 & & & * \\
\hline Габбро островодужный & 539 & 0.2111 & 0.513088 & +7.8 & & & * \\
\hline Кв. диорит коллизионный & 520 & 0.1497 & 0.512862 & +7.5 & & & * \\
\hline \multicolumn{8}{|c|}{ Монголия } \\
\hline \multicolumn{8}{|c|}{$\begin{array}{c}\text { Баян-Хонгорская островная дуга } \\
\text { Островодужный и внутриплитный магматизм }\end{array}$} \\
\hline Базальт (гайот баян-хонгорский) & $665 \pm 15$ & & & +9.8 & 1451 & & [Kovach et al., 2005] \\
\hline Долерит (дайка) & 577 & & & +11.5 & & & [Kovalenko et al., 2005] \\
\hline Расслоенное габбро & * & & & $+7.9 \ldots+8.1$ & & & * \\
\hline Пиллоу-лавы базальтов & * & & & +9.1 & & & * \\
\hline Габбро (ханулинский) & 570 & & & $+7.8 \ldots+8.6$ & & & $*$ \\
\hline \multicolumn{8}{|c|}{$\begin{array}{c}\text { Герциниды } \\
\text { Средний - верхний палеозой }(0.42-0.25 \text { млрд лет) }\end{array}$} \\
\hline \multicolumn{8}{|c|}{ Забайкалье } \\
\hline \multicolumn{8}{|c|}{ Островодужный и плюмовый магматизм } \\
\hline Базальт (кулиндинская) & $475-385$ & & & +2.8 & & 583 & [Dril, Golubev, 2003] \\
\hline Риолит (уендэктская) & 407 & 0.129622 & 0.511886 & -11.2 & 2287 & 2094 & [Doronina et al., 2016] \\
\hline Трахириодацит (уендэктская) & 402 & 0.139459 & 0.511784 & -13.7 & 2794 & 2300 & $*$ \\
\hline Метаандезит (ципиканская) & 324 & 0.1353 & 0.511948 & -11.0 & 2331 & 2005 & [Ruzhentsev et al., 2012] \\
\hline Метадолерит (ципиканская) & 321 & 0.15500 & 0.512338 & -4.2 & 2106 & 1441 & * \\
\hline Андезибазальт (точерская) & 314 & 0.149524 & 0.512341 & -3.9 & 1920 & 1415 & $*$ \\
\hline Габбро (сивакский) & 312 & 0.119064 & 0.512088 & -7.6 & 1710 & 1724 & * \\
\hline Гранит (баунтовский) & 311 & 0.103310 & 0,511877 & -11.5 & 1756 & 2013 & * \\
\hline Гранит (витимканский) & 311 & 0.103310 & 0.511877 & -11.14 & 1756 & 2013 & * \\
\hline Андезибазальт (сурхебтинский) & 306 & 0.148725 & 0.512545 & +0.1 & 1422 & 1080 & [Gordienko et al., 2010] \\
\hline Габбро-диорит (атарханский) & 315 & 0.174440 & 0.512667 & +1.5 & 1878 & 971 & [Hegner et al., 2006] \\
\hline Гранитоиды Ангаро-Витим.батолита & $330-290$ & 0.112964 & 0.511893 & $-8.5 \ldots-11.9$ & 1700 & 2058 & [Tsygankov et al., 2017b] \\
\hline Гранитоиды Хангайского батолита & $260-240$ & 0.11055 & 0.511851 & $-3.1 \ldots-12.6$ & 1308 & 2088 & [Yarmolyuk et al., 2016] \\
\hline Гранит (ушминский) & 287 & 0.129239 & 0.512552 & +0.8 & 1082 & 1004 & [Ruzhentsev et al.,2012] \\
\hline Габбро (арсентьевский) & 285 & 0.1279 & 0.5125 & -0.2 & 1157 & 1084 & [Gordienko et al., 2019a] \\
\hline Габбро (оронгойский) & 285 & 0.1425 & 0.5125 & -0.7 & 1394 & 1128 & $*$ \\
\hline
\end{tabular}


Таблица 1. (продолжение)

Table 1. (continued)

\begin{tabular}{|c|c|c|c|c|c|c|c|}
\hline $\begin{array}{l}\text { Порода } \\
\text { (свита, толща, комплекс, массив) }\end{array}$ & $\begin{array}{l}\text { Возраст, } \\
\text { млн лет }\end{array}$ & ${ }^{147} \mathrm{Sm} /{ }^{144} \mathrm{Nd}$ & ${ }^{143} \mathrm{Nd} /{ }^{144} \mathrm{Nd}$ & $\varepsilon_{\mathrm{Nd}}(\mathrm{T})$ & $\begin{array}{l}\mathrm{T}_{\mathrm{ND}}(\mathrm{DM}), \\
\text { млн лет }\end{array}$ & $\begin{array}{l}\mathrm{T}_{\mathrm{ND}}(\mathrm{DM}-\mathrm{st}) \\
\text { млн лет }\end{array}$ & Источники \\
\hline * & 278 & 0.103328 & 0.5126 & +2.6 & 762 & 831 & * \\
\hline Габбро (альбитуйский) & 371 & 0.161270 & 0.512611 & +1.2 & 1569 & 1042 & Author's \\
\hline Базальты (гайот уртуйскиий) & 350 & & & +2.8 & 712 & 1096 & $\begin{array}{l}\text { [Ruzhentsev, Nekrasov, } \\
\text { 2009] }\end{array}$ \\
\hline Кварцевый диорит (атарханский) & $336 \pm 3$ & & & $+2.1 \ldots+2.5$ & 870 & 830 & [Rytsk et al., 2013] \\
\hline Габбро (шарагольский) & 330 & 0.123544 & 0.512702 & +4.3 & 761 & 744 & Author's \\
\hline Гранит (ундинский) & 275 & & & -5.0 & 1472 & 1210 & $\begin{array}{l}\text { [Ruzhentsev, Nekrasov, } \\
\text { 2009] }\end{array}$ \\
\hline Габбро (урлукский) & 247 & 0.132906 & 0.512946 & $+8,0$ & 388 & 369 & Author's \\
\hline \multicolumn{8}{|c|}{ Б. Результаты Sm-Nd изотопных исследований осадочных пород } \\
\hline Метаосадки (кичерская) & $1000-850$ & 0.1348 & 0.511363 & -17.8 & 3430 & 2829 & [Rytsk et al., 2007] \\
\hline Метаосадки (киндиканская) & 1000 & 0.1375 & 0.512117 & -2.6 & 2063 & 1782 & $*$ \\
\hline Метапесчаник (олокитская) & 900 & 0.1098 & 0.512096 & -10.6 & 1546 & 1547 & * \\
\hline Метаосадки (хойготская) & 780 & & & $-1.7 \ldots-7.2$ & 2000 & 1800 & * \\
\hline Метаосадки (суванихинская) & 780 & & & $-5.8 \ldots-10.1$ & 2300 & 1800 & $*$ \\
\hline Метапесчаник (ципиканская) & 767 & 0.11130 & 0.512043 & -7.5 & 1648 & 1765 & [Doronina et al., 2016] \\
\hline Метаграувакки (няндонинская) & 750 & 0.1351 & 0.512556 & 4.3 & 1155 & 1057 & $*$ \\
\hline Метаосадки (хасуртинская) & 540 & 0.1457 & & $+3.1 \ldots+3.7$ & 1800 & 1600 & [Makrygina et al.,2010] \\
\hline Метапесчаник (олдындинская) & 530 & & & $-8.7 \ldots-1.3$ & 2000 & 1400 & Author's \\
\hline Метаосадки (олдындинская) & 529 & & & $-5.8 \ldots-10.1$ & 2300 & 1800 & [Ruzhentsev et al., 2012] \\
\hline Метаосадки (кулиндинская) & 475 & & & $-6.3 \ldots+2.8$ & 1470 & 1100 & [Dril, Golubev, 2003] \\
\hline
\end{tabular}

